
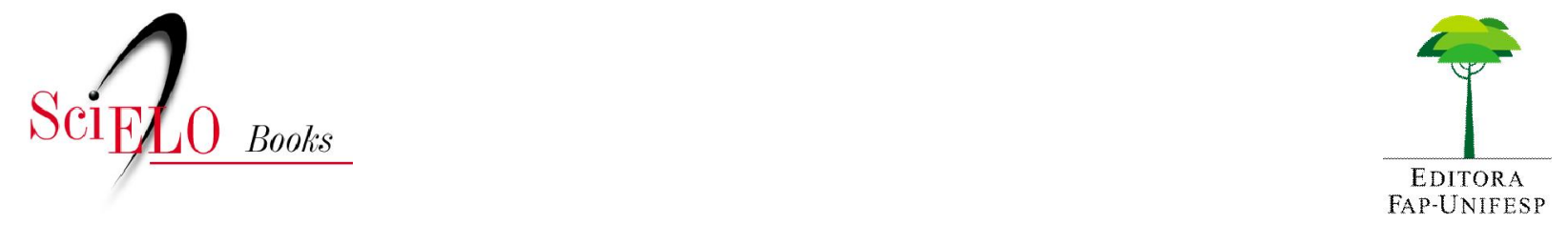

\title{
I Comemorações, memória, história e identidade
}

\author{
Karen Macknow Lisboa
}

\section{SciELO Books / SciELO Livros / SciELO Libros}

LISBOA, KM. I Comemorações, memória, história e identidade. In RODRIGUES, J., org., NEMI, ALL., LISBOA, KM., and BIONDI, L. A Universidade Federal de São Paulo aos 75 Anos: ensaios sobre história e memória [online]. São Paulo: Unifesp, 2008. pp. 35-91. ISBN: 978-85-61673-83-3. Available from SciELO Books $<\underline{\text { http://books.scielo.org }>\text {. }}$

\section{(1) (1) $\Theta(9)$}

All the contents of this work, except where otherwise noted, is licensed under a Creative Commons Attribution-Non Commercial-ShareAlike 3.0 Unported.

Todo o conteúdo deste trabalho, exceto quando houver ressalva, é publicado sob a licença Creative Commons Atribuição Uso Não Comercial - Partilha nos Mesmos Termos 3.0 Não adaptada.

Todo el contenido de esta obra, excepto donde se indique lo contrario, está bajo licencia de la licencia Creative Commons Reconocimento-NoComercial-CompartirIgual 3.0 Unported. 


\title{
I \\ Comemoraçóes, Memória, História e Identidade
}

\author{
Karen Macknow Lisboa \\ A matriz mitica se conserva porque é periodicamente refeita \\ com noçóes que correspondem ao presente histórico. \\ Marilena Chauí, O que é Comemorar? \\ - Poderia vossa excelência destacar alguns nomes dos que mais \\ têm contribuido para o desenvolvimento da EPM? \\ - A EPM é um só bloco dirigido por um só sentido: \\ o seu aperfeiçoamento. \\ Felipe Figliolini, vice-diretor da EPM, em entrevista concedida \\ à revista $O$ Estudante, em 25 de junho de 1943 , \\ quando da efeméride de dez anos da criação da EPM.
}

\section{As Comemoraçóes como Lugares da Memória}

COMEMORAÇÓES FAZEM PARTE da vida social, nas esferas pública e privada. Nascimentos, casamentos, aniversários são motivos para celebraçóes no cotidiano privado. Igualmente na esfera pública, festejamse aniversários de datas consideradas historicamente importantes, tais como "descobertas" de territórios ou saberes, de fundaçôes de cidades, de instituiçóes, de nascimento e morte de personagens, de publicaçóes de obras e assim por diante. 
I. Pierre Nora, "L'ère de la commémoration”, em Pierre Nora (dir.), Les lieux de mémoire, pp. 4687-4688.

2. Idem, pp. 4687-4719. Tradução da autora.
No entanto, o que nos parece bastante natural não seria assim, se não nos pensássemos num tempo cronológico e histórico - conforme sugere o historiador Pierre Nora. Ou seja, as comemoraçóes são fenômenos das sociedades contemporâneas laicizadas, em que as grandes datas históricas tomaram o lugar das datas cristâs ${ }^{\mathrm{I}}$. Os aniversários redondos, os jubileus de prata, de ouro, de diamante, os "cem anos" etc., testemunham uma íntima relação entre a passagem do tempo cronológico e o consenso de que essas datas sejam festejadas com maior ênfase. Nesse sentido, os aniversários da EPM e, posteriormente, da Unifesp, seguem um calendário bastante convencional, apontando para essa tradição da sociedade ocidental moderna de comemorar os fastos históricos.

Conforme foi possível apurar neste presente trabalho, a partir do exame de documentos oficiais, livros comemorativos, jornais, programações, correspondência institucional, a EPM - criada em I933 - autocelebrou-se pela primeira vez aos dois anos de existência. Mas foi a partir do décimo aniversário que as comemoraçóes paulatinamente cresceram e mudaram, bem como repetiram aspectos apontando para uma ritualização (e reatualização) do próprio ato comemorativo. Festejaram-se os aniversários de dez e vinte anos, o jubileu de prata, os trinta e os quarenta anos, o jubileu de ouro, os sessenta e os setenta anos. Cada uma dessas comemoraçóes tinha as suas especificidades, mostrandonos que os atos comemorativos têm sua historicidade, acontecendo em diferentes contextos, e que podem ser compreendidos como um objeto de estudo do historiador.

É isso que Pierre Nora nos ensina em seu capítulo "L’ère de la commémoration", ao analisar e discutir os contextos políticos, culturais e sociais nos quais foram comemorados, na França, o Maio de I968, o bicentenário da Revolução Francesa, o milênio capetíngio, o tricentenário da revogação do Edito de Nantes, entre outras datas festivas da história francesa - ou seja, uma história nacional. Nesse percurso, Nora demonstra como o presente cria os "instrumentos da comemoração, moldando-os conforme suas necessidades e especificidades, bem como a própria simultaneidade das efemérides assumem relevância nas relaçóes políticas e no imaginário nacional, projetam representantes políticos" 2 .

Como objeto de estudo do historiador, cabem então algumas palavras para compreender o fenômeno da comemoração na sociedade ocidental cujos valores compartilhamos, seguindo mais uma vez os passos de Nora. O historiador francês argumenta que as comemoraçôes são, por excelência, gestos que demarcam os "lugares da memória" 
(lieux de mémoire), um conceito que sintetiza as relaçôes entre a história e a memória ${ }^{3}$. Embora a obra verse sobre os lugares da memória no contexto da história francesa e no âmbito da nação, em sua discussão teórica há algumas indicações que nos são úteis para pensar o sentido das comemoraçóes - no caso, o aniversário de uma instituição de ensino superior.

No entender do autor, memória e história não são sinônimos. A memória é a vida, protagonizada pelas pessoas, em grupo, e está em evolução permanente. Aberta para a dialética da lembrança e do esquecimento, a memória não tem consciência de sua sucessiva deformação e, vulnerável a todas as utilizaçóes e manipulaçóes, é suscetível a longas latências e repentinas revitalizações. A história é a reconstrução sempre problemática e incompleta do que já passou. A memória é um fenômeno sempre atual, uma ligação vivida no eterno presente, ao passo que a história é uma representação do passado ${ }^{4}$.

"O estudo dos lugares da memória se encontra justamente no cruzamento desses dois movimentos"s, lá onde a memória cruza-se com a história. Os lugares da memória nascem e vivem do sentimento de que não há mais memória espontânea. Nora entende que a necessidade de se criar arquivos, de manter os aniversários, de organizar celebraçóes, de pronunciar necrológios, de lavrar atas e assim por diante são operaçóes que nada têm de natural e espontâneo ${ }^{6}$. São atos dotados de uma complexidade que se revela pelo fato de tocarem três dimensóes: a material, a simbólica e a funcional. Por exemplo, um arquivo - algo de caráter material - somente torna-se lugar da memória quando investido de uma aura simbólica. Ou algo muito funcional, como um livro escolar, um testamento, uma associação de ex-combatentes precisa passar por alguma forma de ritualização para vir a ser um lugar da memória. Até um minuto de silêncio, algo prenhe de extremo significado simbólico, tem a sua materialidade enquanto recorte de uma unidade temporal e serve como uma evocação concentrada da lembrança. Nora quer com isso dizer que as três instâncias coexistem sempre. Mas o fundamental é que haja, por princípio, o desejo pela memória ${ }^{7}$.

Nessa linha, as efemérides da EPM e Unifesp podem ser vistas como um lugar da memória da instituiçãa. Podemos observar, por meio de evidências, a contribuição dos indivíduos e a memória que eles constroem e reconstroem sobre a instituição. Ao mesmo tempo, são elaboradas obras historiográficas sobre a EPM que, a despeito de não terem sido escritas por punhos de historiadores, figuram como representaçôes do passado.

\footnotetext{
3. Pierre Nora, "Entre mémoire et histoire: la problématique des lieux", op. cit., tomo I, p. 4I.

4. Idem, pp. 24-25. Nora aprofunda a análise da mudança desses conceitos diante das rupturas engendradas pelas vanguardas modernas do início do século $\mathrm{xx}$, possibilitando que a história deixasse de ser pedagógica e portadora única da identidade nacional, dessacralizando a idéia de nação. A história tornava-se uma ciência social, e a memória assumia, cada vez mais, a dimensão individual, de fenômeno privado (pp. 27-28).

5. Idem, p. 28. Tradução da autora.

6. Idem, p. 29.

7. Idem, p. 37.
} 
Como tentarei mostrar nas páginas que se seguem, as efemérides seguiram certo ritual, ou seja, apresentaram-se ao longo dos anos atividades semelhantes, adaptadas às mudanças da instituição e do contexto no qual se vive. Há uma dimensão simbólica, expressa nas próprias falas e discursos dos sujeitos, em que o passado, o presente e o futuro da instituição são concebidos conforme a experiência pessoal - são várias memórias pessoais que, no entanto, repetem-se e assemelham-se entre si em alguns aspectos em função da celebração. Nesse sentido, a recorrência da citação parcial ou total do Manifesto dos Fundadores ocupa especial relevância simbólica, sugerindo a perpetuação de características que são "herdadas" pelas sucessivas geraçóes. Tributário do Manifesto, o mito do bandeirante e da força espiritual dos paulistas, como aura que acompanha a existência da EPM e de seus membros desde sua criação.

Além das memórias, como veremos, nos atos festivos não faltaram cultos religiosos (ecumênicos ou não) e atos solenes, além de jantares e encontros de confraternização, encontros científicos, palestras e torneios esportivos. Em um dos aniversários, fez-se um minuto de silêncio em memória aos fundadores falecidos; em outro, uma visita a túmulos de professores. Num terceiro, a composição de poemas e hinos em homenagem à Escola. Também as inauguraçóes de bustos e placas faziam parte dos rituais, expressando simbolicamente as homenagens a pessoas que contribuíram para a existência promissora da instituição. Além disso, as comemoraçóes serviam como momentos oportunos para inaugurar novas dependências da instituição.

A dimensão material e funcional também se revela nas "coisas" produzidas para a celebração, tais como selos, cartazes, programas, convites, bandeiras, brochuras, livros, vídeos, entrevistas, placas, bustos, diplomas etc., mas que nada significariam se descontextualizados daquilo que pretendem simbolizar. Finalmente, a comemoração convida a lembrar e refletir sobre a vida institucional, a escrever a (heróica) história dela, a homenagear sua existência e, com isso tudo, perfilar e fortalecer sua identidade. Uma identidade criada pelos seus membros e que, ao mesmo tempo, empresta a eles mesmos certa identidade que se projeta na esfera individual. Essa é também uma identidade que se forja em resposta ao que há fora da instituição. Para citar o exemplo mais evidente: a constante lembrança de que a EPM nasceu em função da demanda não atendida pela Faculdade de Medicina de São Paulo parece ter um forte caráter normativo para a auto-imagem da EPM. Outra função que as efemérides assumiram é o seu papel de garantir as

8. O tema será discutido mais detidamente no capítulo IV. tautologias, sendo que a mais forte me parece ser a questão de figurar como um centro de excelência ${ }^{8}$. 
Enfim, as efemérides, como já anunciei, somente são possíveis em sociedades laicizadas nas quais o tempo é interpretado cronológica e náo ciclicamente. Isso, porém, não rompe com a idéia das repetiçóes, reiterações e reafirmações de certas características, histórias e memórias que contribuam positivamente para a auto-imagem e a identidade da instituição que, ao fim e ao cabo, não pode ser compreendida sem a ação dos sujeitos históricos e as memórias nela envolvidas.

\section{As Primeiras Efemérides}

A história das comemoraçóes da EPM e, posteriormente, da Unifesp, começa muito timidamente. Encontramos menção ao tema no jornal $O$ Átomo de 18 de julho de I935, primeiro periódico editado pelo Centro Acadêmico Pereira Barretto (САРB), no número dedicado ao segundo aniversário da Escola. Nele, as homenagens ainda eram muito acanhadas, se comparadas ao que viria a ocorrer nas décadas posteriores. Comemoração ainda tão discreta que sequer foi mencionada em algum livro de atas ou memória oficial da instituiçãa feita posteriormente.

$\mathrm{Na}$ ocasião, os editores gabavam-se da aceitação que o jovem jornal tinha entre os leitores, e que nessa edição já aparecia com maior número de páginas. A manchete da capa do tablóide não deixava dúvidas quanto à prioridade do assunto: "O anniversário de nossa Escola. DoIs ANNos". Ladeando a matéria, um editorial sublinhava o ensejo festivo - frisando, no entanto, que a vocação do jornal superava as datas comemorativas: "O Átomo é e sempre será uma homenagem à Escola Paulista de Medicina”. A matéria na primeira página apresentava um breve relato da curta história da instituição, testemunhada pelos primeiroanistas. Relembram a aula inaugural de Antônio Carlos Pacheco e Silva, cujas palavras endossaram a sua categoria de "acadêmicos", e dos dois anos que se seguiram:

O que tem sido o embate para construir esse formidável patrimônio moral, somente nós do terceiro ano podemos testemunhar. Nos primeiros doze meses do seu funcionamento, só os alunos do então Io ano sabem como, professores e discípulos caminhavam mutuamente, amparando-se, em busca do mesmo objetivo: a consolidação moral de um conceito perante nossa terra, e, felizmente, obtivemo-lo, condignamente?

A questáo da solidariedade entre alunos e mestres fundadores vinha acompanhada de um forte otimismo que, projetado sobre o passado, procurava construir uma imagem heróica dos criadores da insti- 
Io. Idem, ibidem.

II. "A anormalidade das condiçóes de vida espiritual e material que há longos anos vem assolando a Humanidade, e que tão intensamente tem repercutido em nossa Pátria, não teve o dom de prostrar as energias do espírito paulista. A vitalidade espiritual de São Paulo tem o vigor das forças naturais incoercíveis, a que o homem pode dar uma direçăo, mas nunca opor um obstáculo eficaz". Manifesto da Escola Paulista de Medicina, $\mathrm{I}^{\mathrm{o}}$ jun. I933. Brochura mimeo., Acervo do сенғi, pasta no $35-$ Fundação da EPM.

I2. "Sob os auspícios de cordialidade, de confiança perseverante na sua finalidade filantrópica, os professores da Escola Paulista de Medicina firmaram publicamente o pacto de honra de jamais abandonar o sagrado patrimônio, para melhor servir São Paulo, este orgulho, esta maravilha da civilização contemporânea, em cujo solo germinam e prosperam todas as sementes puras, em cujo ambiente florescem os grandes ideais, em cujo seio, em tempo algum deixaram de frutificar os grandes empreendimentos". Discurso de Octávio de Carvalho quando da inauguração da EPM, Is jul. 1933, em Octávio de Carvalho, História da Escola Paulista de Medicina: Curriculum Vitae, p. 7. Destaque da autora.

I3. O Átomo, I8 jul. 1935, p. I.

I4. O tema será abordado no capítulo iI.

I5. O Átomo, I8 jul. I935, pp. I-2.

I6. Sobre o ideal de excelência cultivado na ЕPM e na Unifesp (após 1994) e seu significado no âmbito da expansão de campi e cursos de graduação ocorrida no século XXI, ver capítulo IV. tuição. Ao mesmo tempo, na projeção para o futuro, vislumbrava-se a certeza do sucesso: "[...] o nosso passado é um campo de batalha, o nosso presente é um sorriso de triunfo e o nosso futuro é um vasto panorama de atividade em cuja vitória estribamo-nos da nossa vontade de moços" ".

Nesse ambiente de bravura auto-atribuída, contava-se a ainda curta, porém "brilhante", história da Escola. As alusóes ao Movimento de I 932, deflagrado em São Paulo em oposição ao governo de Getúlio Vargas, figuravam como argumento importante para explicar a soberba dos paulistas, que se refletia na criação da nova escola de medicina. Essa questão já fora mencionada no Manifesto de Fundação ${ }^{\text {II }}$ e no discurso inaugural de Octávio de Carvalho ${ }^{\text {I2 }}$, o que denota a construção de uma memória comum a mestres e alunos já nos primeiros eventos comemorativos. Como veremos adiante, a ligação com o Movimento de 1932 se perpetuará nas várias narrativas sobre a história da EPM. Por ora, é importante observar os termos em que a questão foi tratada na primeira efeméride: "[...] nos derradeiros dias do movimento e memorável ano de I932" ocorrem "as primeiras conversaçôes sobre as possibilidades da fundação de uma escola médica" ${ }^{\text {‘3 }}$, conduzidas por Octávio de Carvalho e Marcos Lindenberg.

$\mathrm{O}$ artigo d'O Átomo sintetiza as freqüentes reunióes entre os membros fundadores, as sucessivas adesóes revelando a pertinência do projeto, bem como menciona o vestibular de 1933 na Faculdade de Medicina de São Paulo em que um grande número de aprovados, embora tendo obtido nota suficiente, não conseguiu ingressar no curso ${ }^{14}$. Esses alunos seriam os futuros candidatos da vindoura escola, que "surgia [...] para preencher as necessidades de nossa terra”. $\mathrm{O}$ vestibular não tardou: em meados de I933, foram realizadas as provas, ao mesmo tempo em que era escolhido o local para abrigar a nova escola - rua Cel. Oscar Porto, 54, casa que, em 1935, "nada deixa a desejar". Os demais eventos, naquela altura, eram o tempo presente: o artigo menciona os trâmites burocráticos para o reconhecimento da EPM junto ao Conselho Nacional de Educação, o ingresso de novas turmas, bem como o projeto de dois hospitais, o Piratininga e o São Paulo, com os quais a Escola daria um "grande passo para resolver um importantíssimo problema que preocupa São Paulo, qual seja a assistência aos doentes". Finalizando o texto, reiterava-se a vocação da EPM na assistência médica, "afim de melhor servir aos paulistas e para mostrar aos brasileiros que ela representa uma eficiente casa de estudos médicos" ${ }^{\text {Is. }}$ Nota-se que a construção da idéia da "excelência" como distintivo da EPM já se coloca desde os primórdios ${ }^{16}$. 
Em I943, a EPM completava dez anos, momento considerado propício para uma comemoração de maior alcance entre a comunidade epemista e o público médico em geral. Também foi nessa ocasião que o novo jornal do САРB, refundado e rebatizado como $O$ Bíceps, produziu uma bela edição comemorativa (Figura I).

As imagens de crescimento e perenidade da EPM seriam reiteradas no discurso de aniversário pronunciado por Álvaro Guimarães Filho, um dos fundadores e terceiro diretor da Escola, publicado na segunda página dessa edição. Antes disso, o leitor tinha a oportunidade de (re)ler o Manifesto de Fundação da EPM e de acompanhar a lista dos signatários do documento.

As palavras celebrativas de Álvaro Guimarães, proferidas em seção solene da Congregação em I 5 de julho de 1943 - exatamente dez anos após o discurso de Octávio de Carvalho e a aula inaugural de Pacheco e Silva - rememoravam o momento da fundaçáo e sublinhavam a especificidade de São Paulo, citando o Manifesto: "A vitalidade espiritual de São Paulo tem o vigor das forças naturais incoercíveis, a que o homem pode dar uma direçáo, mas nunca opor um obstáculo eficaz" ${ }^{17}$. Nesse salto da memória, Guimarães retomava os três aspectos que teriam norteado o Manifesto e seus signatários: a suposta força espiritual de São Paulo, alçado à condição de sujeito histórico com voz e vontade; os fundadores apresentados como "idealistas", trabalhadores e altruístas e as condiçóes peculiares da medicina no Brasil - ou seja, a carência de médicos fora dos centros urbanos, a falta de vagas para estudantes em Sáo Paulo forçando os jovens a emigrar para cursar o ensino superior em outras localidades, "arriscando duplo dano moral e material constituído pela perda do ambiente familiar em época de amadurecimento psíquico e de formaçáo moral". Acima de tudo, o êxito teria sido possibilitado pelos "pendores didáticos dos que a organizaram, o amor ao trabalho penoso, mas produtivo de seus fundadores, o desinteresse altruístico dos que com eles cooperaram e o idealismo sadio de quem pretende colaborar em prol da educação da nossa gente e da melhoria das condiçóes médico-sociais do nosso país" ${ }^{18}$.

Por fim, a atualidade do Manifesto era reposta em uma longa citação no discurso de Guimarães:

A premência de dois problemas - o do ensino médico e o da assistência hospitalar - bastaria para justificar amplamente a presente iniciativa; por outro lado, o elevado grau de desenvolvimento já referido, alcançado entre nós pela cultura médica, e o interesse que São Paulo sempre dedicou às manifestaçôes da atividade intelectual, são motivos que legitimam a certeza que a nova Escola nasce com mais seguro elemento de vitalidade ${ }^{19}$.

I7. O Biceps, 6 (17), set. 1943, p. 2.

I8. Idem, ibidem.

19. Idem, ibidem. 


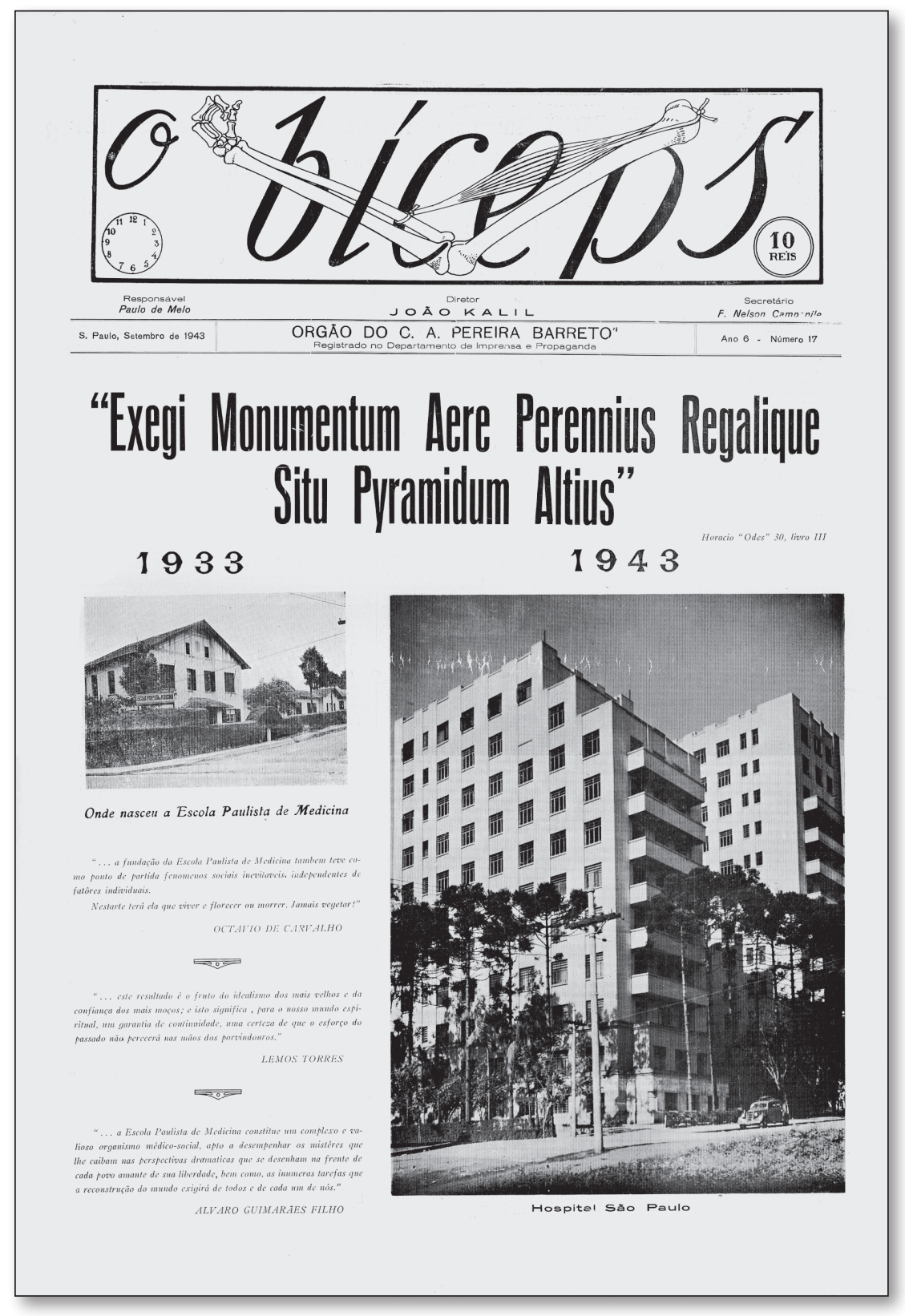

Figura I. A edição de setembro de I943 d'O Bíceps reproduzia, na manchete de capa, uma citação em latim extraída de Horácio (Odes, 30, livro III): Exegi Monumentum Aere Perennnius Regalique Situ Pyramidum Altius ("Levantei uma obra mais perene que o bronze, mais alta que as pirâmides reais”, na tradução livre de Rafael Ruiz, a quem agradeço). A intelecção do aforismo se completa pelas imagens reproduzidas abaixo da citação no original: no lado esquerdo, vemos uma fotografia da casa onde a Escola instalou-se inicialmente (na rua Cel. Oscar Porto) e, ao lado direito, uma ampla fotografia do prédio do HSP, inaugurado em I 942. A composição da página não deixa margem para dúvidas, ressaltando o vultuoso crescimento institucional e a perenidade como busca. 
Guimarães sublinhou também os termos finais do Manifesto, reafirmando que os signatários se congregaram em uma sociedade civil "despidos de qualquer intenção de lucro material" ${ }^{20}$. Ele não deixou de perceber que, em I943, essas palavras soavam de modo peculiar, tendo em vista o quanto a EPM teria mudado nesses dez anos. Em seu discurso, traçou uma visão geral da Escola, do funcionamento dos cursos, da ocupação dos cargos docentes, da formação do САРB e da abertura do Colégio Pan-Americano, voltado para a formação secundária de boa qualidade e de vestibulandos para a EPM. Em destaque, tematizou o desdobramento do ensino médico já praticado com desenvoltura para a assistência médica, por meio da construção e equiparação do HSP. Nesse passo, os elogios à Caixa Econômica Federal não poderiam ser omitidos. Naquele momento, o Hsp funcionava com uma fração do que se previa no projeto original, graças à "benemérita e patriótica visão que dos problemas sociais tem a Caixa [...]. Esse instituto financeiro e econômico [sic] julgou corresponder fielmente à sua finalidade de depositária dos dinheiros do povo, amparando e prestigiando a criação do HSP, por ver nele um instrumento idôneo de reversão, ao povo e ao pobre, das economias que recolhe" ${ }^{21}$.

Guimarães mencionou também a criação da Escola de Enfermagem, reconhecida em I 942, e o curso de formação para auxiliares técnicos de laboratório, iniciativa pioneira no país. Em suas palavras de encerramento, apresentou um balanço positivo dos anos de existência, focado na "excelência":

Com esse conjunto na verdade magnífico de realizaçôes, a Escola tem hoje a consciência tranqüila de que cumpriu, na medida da humana possibilidade, as promessas de seu Manifesto de Fundação. Sua estabilidade científica, moral e econômica decorre não apenas do espírito de sacrifício com que foi criada e conduzida. Ela se funda por igual, na legitimidade com que se integra no espírito do art. I 28 da Constituição Federal de $1937^{22}$.

Foram recuperadas e incorporadas as observaçóes elogiosas que Gustavo Capanema, Ministro da Educação e Saúde Pública, teceu sobre a Escola, quando da visita feita em abril de I943:

O idealismo, o desinteresse e o trabalho dos professores e alunos dessa casa de ensino, constituem exemplo para a vida universitária do nosso País. E mostram mais que o estabelecimento merece o apoio e colaboração de quantos saibam que é no ensino de boa qualidade que reside um dos fundamentos, o maior fundamento do progresso e da grandeza de nossa Pátria ${ }^{23}$.
20. O Bíceps, 6 (17), set. 1943, p. 2. As contribuiçōes financeiras feitas pelos fundadores são assunto tratado em diversas obras dedicadas à história da EPM. Entre outros, ver Álvaro Nagib Atallah, Regina Celes de Rosa Stella e Ulysses Fagundes Neto, "Escola Paulista de Medicina - Universidade Federal de São Paulo", em Gilberto Natalini e José Luiz Gomes do Amaral, 450 Anos de História da Medicina Paulistana, p. I76, e o capítulo II deste livro.

21. Idem, ibidem.

22. Idem, p. 6. De acordo com o que estabelecia a citada lei, o texto sugeria ainda que a arte, a ciência e o ensino são livres à iniciativa individual, coletiva ou pública, e que o Estado deveria estimular seu desenvolvimento, direta ou indiretamente.

23. Idem, ibidem. 
24. Idem, ibidem.

25. Depoimentos de Pacheco e Silva, Moacyr de Freitas Amorim, Felício Cintra do Prado, Pedro de Alcantara, Paulo de Toledo Artigas, Sylla O. Mattos, Felipe Figliolini, José Ribeiro do Valle, Ary de Siqueira, José Medina, Pereira Barretto Neto, Armando A. Marques, Walter Leser e Nicolau Rossetti. Idem, p. 8.

26. Idem, ibidem.

27. Nesta ocasiấo, ele repetiu as palavras que proferira na aula inaugural de $1933 \mathrm{e}$ evocou o papel de São Paulo: "Eu creio firmemente no êxito desse empreendimento, porque ele nasce em Sáo Paulo, nesta amada terra nossa, onde tudo cresce, vive e prospera. Descrer seria negar as virtudes da raça. Jamais aqui fracassou empresa, por mais grandiosa e temerária que parecesse à primeira vista, quando firmada em bases seguras, em princípios severos, em ideais alevantados". Idem, ibidem.

28. Idem, p. 4. Julianelli fora presidente da diretoria de 1942 do САРB e, nesta ocasiáo, era o segundo orador da Associação dos Ex-Alunos. Formou-se em 1942 na EPM e fez carreira na política partidária: de 1973 a I975, presidiu a Assembléia Legislativa de São Paulo, renunciando ao posto após assumir cargo de deputado federal, pela Aliança Renovadora Nacional (Arena, o partido da situação durante a ditadura militar), em 1975. Ver http://www.al.sp.gov.br/ web/acervo/presidentes_alesp/jose_julianelli.jpg, acesso em jan. 2008.
As menções às forças humanas, como os fundadores e as instituiçóes governamentais, referendavam a marcha inexorável do progresso da Escola, observada no ano do décimo aniversário como se estivesse posta desde o ato inaugural. Fechando o discurso, Guimarães reportava-se a outras forças, de natureza etérea e que, mesmo com seus contornos indefiníveis, podiam ser reconhecidas como atuantes no plano da história da maneira como ele a concebia. Primeiramente, a Providência Divina - que teria ajudado na realização da obra. Por fim, não poderia faltar uma referência a São Paulo, "bendita terra” em cujo solo nasceu "mais uma instituição digna de seus filhos, para o bem do desprotegido doente e para o engrandecimento da cultura do Brasil" ${ }^{24}$. É como se o telúrico se unisse ao divino, propiciando a materialização de projetos assistenciais que contribuíam para o engrandecimento da nação como um todo.

Nessa mesma edição, foram incluídos comentários laudatórios dos "mestres" sobre a Escola, muitos deles membros do grupo de fundadores $^{25}$. O tom era de reconhecimento pelo trabalho realizado com êxito ao longo de dez anos, que conseguiu transformar um sonho em realidade graças à qualidade do corpo docente, criando uma "casa de ensino modelar" (Toledo Artigas). Finda essa década, a ЕPM "viva, vitoriosa" figurava "como um dos mais elevados padróes de orgulho para o povo de S. Paulo" (Rossetti) ${ }^{26}$. Para Pacheco e Silva, o tempo e os fatos confirmavam as previsóes articuladas dez anos antes e, por essa razão, sentia-se feliz por ter previsto com tamanha segurança "o triunfo da Escola Paulista de Medicina" ${ }^{27}$. A homenagem aos mestres fundadores foi sintetizada numa galeria de retratos fotográficos iniciada naquela edição e que teria continuidade em ediçóes subseqüentes. Abaixo de cada fotografia, constavam o nome e, conforme a importância, o cargo de quem recebia a deferência.

O Centro Acadêmico também soube aproveitar a efeméride, pois fora fundado logo após a Escola, também em I933 (Figura 2). Na edição comemorativa, publicaram-se artigos sobre sua história, focados nas solenidades de posse da primeira diretoria e de suas realizaçóes, sobretudo a do ano de I943. O discurso de José Salvador Julianelli, proferido durante os festejos, dirigia-se aos estudantes, aos médicos, às autoridades militares e eclesiásticas, ao público em geral, ao diretor da escola, e às autoridades presentes, que eram ninguém menos que o Ministro da Educação e Saúde, Gustavo Capanema, e o Secretário da Educação, Teotônio Monteiro de Barros Filho ${ }^{28}$. 


\section{ESCOLA PAULISTA DE MEDICINA}

CENTRO ACADÊMICO "PEREIRA BARRETTO"

\section{ANIVERSÁRIO}

1943

\section{Programa dos festejos comemorativos}

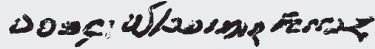

Figura 2. A efeméride foi organizada pelo CAPB junto com a EPM. Iniciou em I I de julho com a abertura da Semana de Enfermagem e encerrou-se em I 9 de julho com a inauguração do aparelho de roentgenfotografia do Centro de Higiene Social da EPM. Álvaro Guimarães, diretor da EPM, proferiu discurso de abertura e a conferência ficou a cargo de Felipe Figliolini sobre o "Papel da Mulher na Sociedade, Vista por um Médico”. Os temas do encontro, do qual participaram médicos e enfermeiras, se voltaram à obstetrícia e pediatria. As atividades incluíram romaria aos túmulos dos profs. Álvaro de Lemos Torres e Fausto Guerner; almoço no Hotel Terminus, banquete da Congregação da EPM no Automóvel Clube; missa em ação de graças na Capela do HSP e sessão solene da Congregação da EPM no Teatro Municipal com recital de piano.

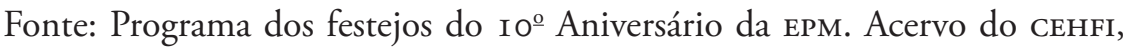
pasta no I 5 - Aniversários da EPM e ex-alunos, documento A4. 
29. Paulo Mangabeira Albernaz, A Escola Paulista de Medicina: Notícia Histórica dos Primeiros 25 Anos, p. II6.

30. Escola Paulista de Medicina, Fundada em I de junho de 1933.

3I. Felício Cintra do Prado era o entấo catedrático de Terapêutica Clínica. Para outros dados biográficos, cf. José Ribeiro do Valle, "40ํㅡㄹ Aniversário da EPM", A Escola Paulista de Medicina: Dados Comemorativos de seu $40^{\circ}$ Aniversário (1933-1973) e Anotaçöes Recentes, p. 7I.

32. Sobre as dificuldades enfrentadas nesse contexto, ver capítulo II.

33. Paulo Mangabeira Albernaz, op. cit., p. I43. Jair Xavier Guimarães, presidente da Associaçáo dos Ex-Alunos, foi convidado para expor o programa dos festejos do $20^{\circ}$ aniversário da Escola.

34. Idem, ibidem.

35. José Aletto Netto, nascido em I929, ingressou na EPM em 1948, formandose em 1953.

\section{A epm Completa sua Maioridade}

Os festejos da "maioridade" da EPM, em I95 I, foram tímidos. A iniciativa de comemorar o I 8o aniversário da EPM, em 9 de junho, partiu do CTA, prevendo uma missa em ação de graças e as inauguraçóes do Pavilhão de Patologia e do Departamento de Clínica Médica ${ }^{29}$ (Figura 3). A novidade em relação às celebrações anteriores, que haviam reunido públicos mais amplos em eventos artísticos e científicos, ficou por conta da primeira obra historiográfica que tomava a trajetória da EPM como objeto de reflexáo. Tratava-se do opúsculo intitulado Escola Paulista de Medicina $a^{30}$, sem autoria explicitada, mas que a inscrição das iniciais "FCP" fazem crer que o seu autor seja Felício Cintra do Prado ${ }^{31}$. Em suas poucas páginas, a ediçáo comemorativa expressava empenho em sintetizar a história institucional. Chama a atenção o fato de nela estar reproduzido, logo nas primeiras páginas, o Manifesto de Fundação da EPM e a lista dos signatários. Quase como uma introdução, o Manifesto vem desacompanhado de qualquer comentário explicativo. É como se os seus preceitos fossem auto-explicativos, devessem continuamente nortear a Escola e, face às dificuldades que se anunciavam ${ }^{32}$, valessem como palavra de estímulo e coragem.

Os percalços mantinham-se na comemoração dos vinte anos. $\mathrm{Na}$ data redonda, que poderia ensejar uma celebraçáo ainda mais vistosa que a dos dez anos, houve pouca festa ${ }^{33}$. A crise institucional náo inspirava confraternizaçôes nem balanços históricos da EPM, entendidos tradicionalmente como cerimônias em que se festejava o progresso imanente da instituição. O diretor Jairo Ramos leria um depoimento sobre a situação da Escola durante os festejos comemorativos, na presença do governador do Estado e do prefeito da capital, no intuito de apelar aos poderes públicos para evitar o encerramento das atividades da $\mathrm{EPM}^{34}$. Em 2 de junho, A Gazeta publicou a matéria intitulada "Orgulho de São Paulo e do Brasil. Não Cerrará Suas Portas a Escola Paulista de Medicina" - ao que parece, uma resposta ao apelo feito por Ramos, anunciando publicamente a precariedade da situação financeira da EPM.

Enquanto a crise financeira espalhava insegurança, José Aletto Netto $^{35}$ fixava em versos a veneração que devotava à Escola, emprestando-lhe uma imagem de crescente solidez:

Minha Paulista, minha namorada, / Minha morena, que tem vinte anos [...] / Eras tão pobre, tantos desenganos, / Tanta amargura e foste vergastada, / Ria de ti um bando de ciganos, / Disseram-te infeliz, chamaram-te coitada!

E um dia, te vestiram de esperança, / verde vestido, cor do teu destino, / [...] 


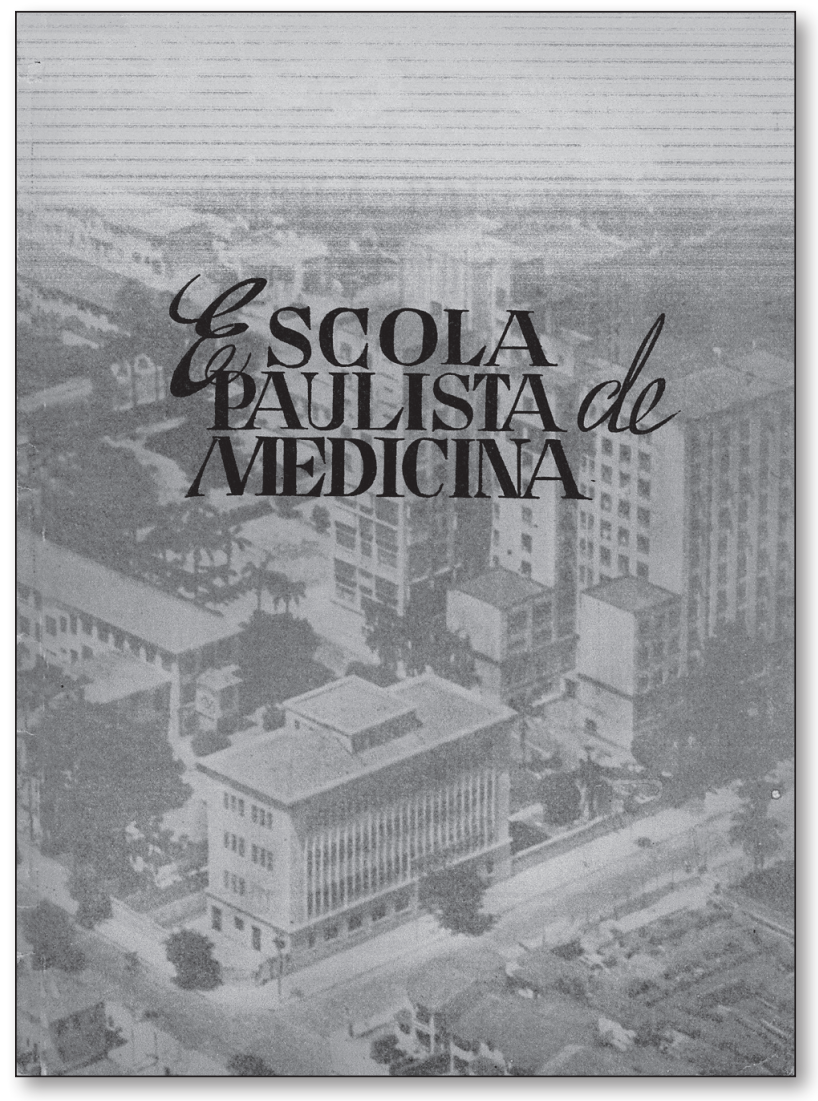

Figura 3. Capa do livro Escola Paulista de Medicina, Fundada em I de junho de 1933.

Cada vez mais me sinto fascinado / Pela infinita graça do teu ar, / Cresces e te avolumas, e a teu lado / Todas as glórias vão formando par. / Sonho de trinta e três, sonhado plasmado / $\mathrm{Na}$ ferida paulista inda viva a sangrar!

Antropomorfoseada em mulher, em morena, em namorada, a EPM figura como um ser vivo, feminino, com o qual o autor mantinha um forte envolvimento emocional. Nesse poema, como em outras fontes, percebe-se o inexorável caminho do crescimento, do desenvolvimento, da superação das dificuldades. O período de fundação é associado à pobreza da instituição, motivo de descrença e chacota (provavelmente Aletto refira-se à Faculdade de Medicina de São Paulo, nas instâncias governamentais e alguns representantes das "elites"). A referência ao contexto paulista de I932 - uma ferida não sarada - explicava a transformação do sonho em realização material. As palavras finais valem como chave de ouro, apontando para o sucesso do empreendimento: “[...] Hoje és feliz, não há mais desenganos, / Nem amarguras minha bem amada, / Já não se ri o bando de ciganos, / Ave! Salve querida Escola idolatrada!" ${ }^{6}$ (Figura 4).

36. José Aletto Netto, "A Bem Querida". Folheto avulso impresso, 1953. Acervo do cehri, pasta no $17-$ Aniversário: Jubileu de Ouro da EPM II. 


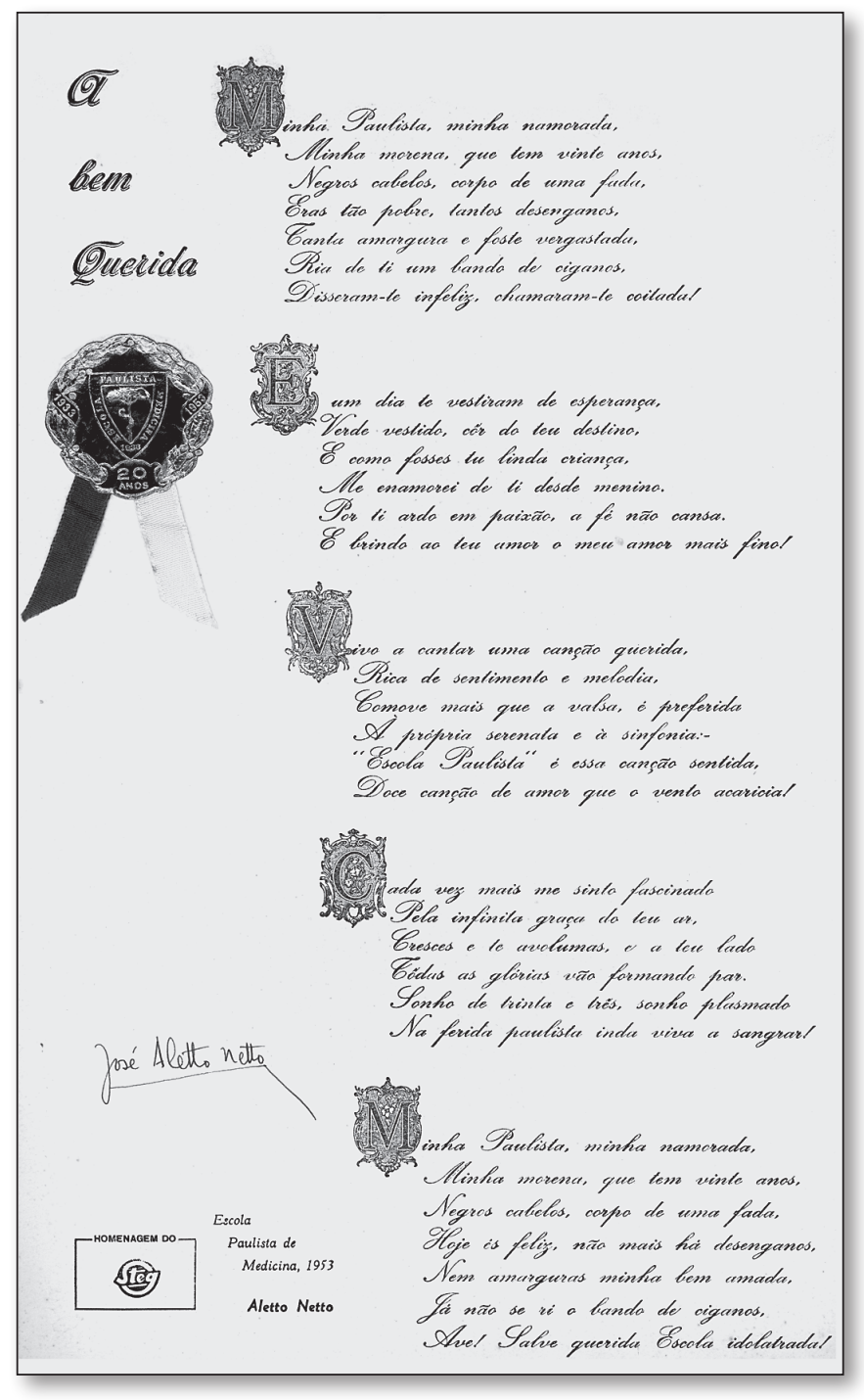

Figura 4. José Aletto Netto, "A Bem Querida", folha avulsa. Fonte: Acervo CEHFI, pasta $\mathrm{n}^{\circ}$ I 7 - Aniversário: Jubileu de Ouro da EPM I I.

37. A ерм fora federalizada pouco antes da posse de Juscelino Kubitschek. O HSP, bem como o terreno por ele ocupado, não foram federalizados e continuaram sob a administração da sPDM. Sobre a federalização, ver capítulo II.

38. Paulo Mangabeira Albernaz, op. cit., p. 2 II.

39. O livro tomaria por base um trabalho elaborado pelo Cônego Luiz de Abreu, capelão do HSP, sobre a história da EPM. Paulo Mangabeira Albernaz, op. cit., "Prefácio" e p. 219.

\section{O Jubileu de Prata}

Em 1957, logo após a federalizaçãa ${ }^{37}$, Felício Cintra do Prado sugeriu a atualização na publicaçáo histórica sobre as atividades da Escola e aproveitou a proximidade do jubileu para encomendar uma nova obra nesse sentido ${ }^{38}$. Em 1958, Prado revelava, em reunião do CTA, não ter tempo disponível para escrever o livro, e o Conselho nomeou Albernaz para a tarefa ${ }^{39}$. $\mathrm{O}$ ano da efeméride já corria, mas o clima não se mostrava propício a celebraçóes, embora a EPM estivesse completando 25 anos de existência. A obra de Albernaz continuou a existir apenas em 
manuscrito e, ainda que a incumbência lhe tivesse sido dada em fevereiro de I958, o livro foi publicado somente em I 968.

Nesse aniversário, a organização das celebrações recaiu novamente sobre o САРB. Sua maior contribuição foi a edição n⿳⺈ I 5 d'O Bíceps, em homenagem ao jubileu de prata. $\mathrm{Na}$ manchete da primeira página, lê-se: "Reagem os paulistas! NOVA ESCOLA MÉDICA PARA SÃO PAULO. Repercute intensamente o resultado dos exames vestibulares da Faculdade de Medicina - nada menos que I 36 candidatos foram aprovados mas não classificados - medidas" ${ }^{\circ \circ}$ (Figura 5 ).

O leitor desavisado se espanta com a manchete e com o texto que abre a matéria correspondente: "Sáo Paulo, I2 de março, I933 (Urgente)". O próprio título indica seu conteúdo, mas com um detalhe pitoresco: $O$ Bíceps teria recebido em sua redação uma comitiva dos moços excluídos, representando os demais, e composta por Wladimir da Prússia Gomes Ferraz, Jair Xavier Guimarães, Helio Corbett Moreira, Romeu Santoro, Horácio Kneese de Mello e Carlos Ary Machado. Na matéria, mais uma vez retomavam-se os argumentos do Manifesto de Fundação para explicar o projeto de criação da nova escola de medicina. Novamente, a migração de estudantes para outros estados e a perda da massa crítica eram apresentadas como "desperdício de material humano"4I.

Uma olhadela nas páginas seguintes fará o leitor observar várias matérias sobre os acontecimentos que formaram e marcaram a instituição, ao longo de um quarto de século, transformados em fatos jornalísticos. No editorial, palavras esclarecedoras sobre o propósito dessa edição especial: não se pretendia escrever uma "história" da Escola e sim "um desenrolar de fatos ocorridos [...], lembranças e coisas que mostram como nasceu, foi se agigantando e chegou a ser o que é, a Escolinha fundada nos idos distantes de I933”. Igualmente, advertia-se que esta não é a sua "história", pois faltariam dados, espaço e senso crítico que os redatores, sendo alunos, ainda não teriam. Por isso, sugerese que homens como Octávio de Carvalho ou Marcos Lindenberg, que viram a Escola desde a concepção, ou outros professores, escrevessem sua história. O que se apresentava na edição deveria ser compreendido como um "guia",

[...] sem ambiçóes, incompleto, mas feito com muito amor. [...] para perder a monotonia que o simples desfilar de fatos históricos poderia trazer, imaginamos fazê-lo nos moldes desse pitoresco e maravilhoso "O Brasil em Jornal”. [...] Mais que uma homenagem, esta edição é um preito à fé. A fé que iluminou trinta e três homens - seus professores - a fundar a EPM, há vinte e cinco anos atrás $[\text { sic }]^{42}$.
40. O Bíceps, 20 (I5), I958, p. I.

4I. Idem, ibidem.

42. Idem, destaque no original. Muito provavelmente, boa parte das reportagens publicadas na edição são transcriçôes e adaptaçôes do que saiu na grande imprensa (Folha da Manhä, Folha da Noite, Diário de São Paulo, O Estado de S. Paulo, A Gazeta, Folha de S. Paulo), desde a fundação até aquele momento. 


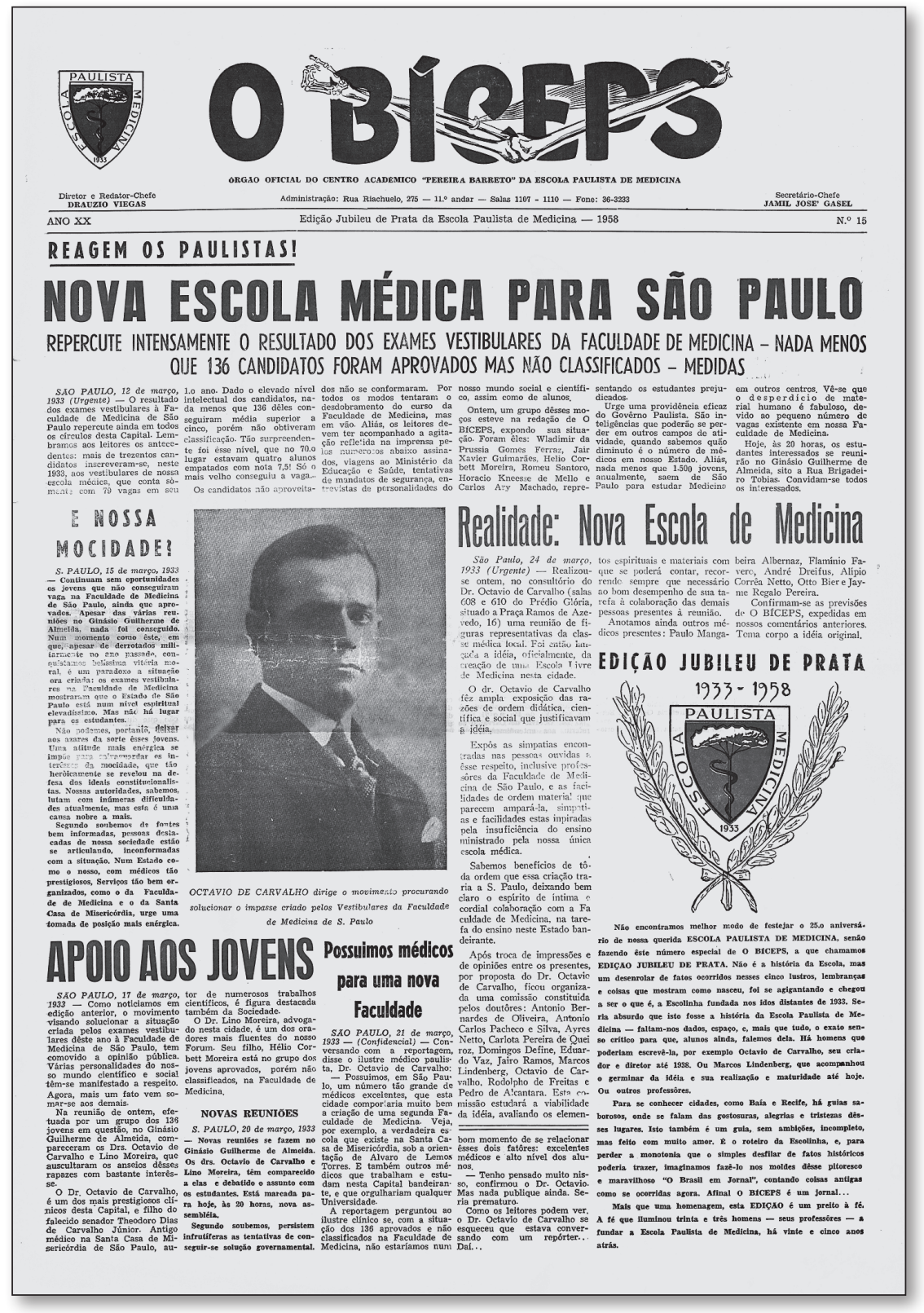

Figura 5. O Biceps, 20 (I5), I958, p. I.

43. Carlos da Silva Lacaz afirma terem sido duas assembléias: " 24 de março de I933: lançada a idéia de criar uma nova escola de medicina, no consultório de Octávio de Carvalho, na Praça Ramos. Dois meses depois, nova assembléia é feita no Instituto Biológico (rua Marquês de Itu), onde se escolhe o nome da instituição (EPM), lança-se o Manifesto de Fundaçấo e escolhe-se o Conselho Deliberativo". Três Escolas de Medicina de Säo Paulo, pp. 46-47.
Por mais que se negasse a pretensão de ser uma história da Escola, a composição cronológica e temática acabava por narrar os acontecimentos "históricos". Na primeira página, o leitor era informado acerca dos momentos imediatamente anteriores à fundação e das primeiras assembléias com os alunos excedentes ${ }^{43}$, quando da formação da comissão organizadora em torno de Octávio de Carvalho e do advogado Lino Moreiro, cujo filho seria um dos aprovados excluídos no vestibular da Faculdade de Medicina de São Paulo em I933. Retomava-se a 
questão da especificidade paulista, sublinhando seu potencial intelectual expresso pelo grande número de candidatos aprovados no exame da Faculdade de Medicina. "Os exames vestibulares da FM mostraram que o Estado de São Paulo está num nível espiritual elevadíssimo. Mas não dá lugar para os estudantes”, revelava a matéria. Igualmente menciona-se o movimento constitucionalista de I932, cuja condução se atribuía a uma mocidade prenhe de ideais. Por fim, a inevitável associação com o bandeirante mítico: na "capital bandeirante" havia médicos suficientes e preparados para lecionar ${ }^{44}$. Numa fictícia entrevista com Carvalho, intitulada "Possuímos Médicos para uma Nova Faculdade", este indica os profissionais orientados por Lemos Torres, da Santa Casa de Misericórdia, com disponibilidade para montar uma nova escola médica ${ }^{45}$.

Acompanhadas de fotografias, várias "reportagens" da edição comemorativa d'O Bíceps narram a fase da fundação ${ }^{46}$. Antes de passar à fase pós-fundação, voltava novamente à cena o Manifesto de Fundação, apresentado com o seguinte título: "Fundada Nova Escola de Medicina em São Paulo". O Bíceps revelava o "sensacional furo": conseguiu, "em primeira mão, uma cópia do manifesto”, transcrito na íntegra, incluindo a lista dos signatários ${ }^{47}$. A criação de mais uma faculdade era vista como uma possibilidade de "se pensar na resolução de vários problemas nacionais". Acatando as observaçôes de uma tendência propalada por certo grupo de higienistas, sublinhava-se que o povo brasileiro era doente porque ignorante, e ignorante porque pobre. E um povo doente seria inútil, em suas palavras. A tentativa de elevar o padrão intelectual do povo estaria ocorrendo por meio da fundação de escolas normais estaduais, ampliando e melhorando o ensino primário. Por outro lado, a erradicação das doenças estaria em marcha lenta, se comparadas com as campanhas de Oswaldo $\mathrm{Cruz}^{48}$.

Além disso, a criação de uma nova escola médica se justificava pelo crescente interesse pela medicina. Com a implantação da Faculdade de Medicina de São Paulo, "fez-se aqui um novo ambiente cultural. A ciência viu-se estimulada. Vocaçóes nasceram”. Mas a Faculdade de Medicina não podia mais absorver o grande número de candidatos aos exames. Por fim, colocava-se em pauta o simples argumento de que havia necessidade de mais médicos. A iniciativa da fundação era vista, assim, como "grandiosa", proposta por Octávio de Carvalho, um "homem talentoso" que reunira em torno de si uma plêiade de "médicos inteligentes, estudiosos". No mais, tratava-se de uma iniciativa "honesta”, pois formou-se uma sociedade civil, sem fins lucrativos, concebida e forjada a partir da doação de dinheiro pelos fundadores ${ }^{49}$.
44. O bandeirante e o bandeirantismo surgem como mito na historiografia laudatória de São Paulo no século xıx e inícios do xx. Nessa construção heróica, o bandeirante é associado ao espírito empreendedor, conquistador, descobridor de novas terras e riquezas. Historiadores como Afonso Taunay e Alfredo Elis Jr. atribuíram aos bandeirantes as atuais dimensōes territoriais do Brasil. Oliveira Vianna os descreveu como mercadores ricos, homens cultos e acostumados ao luxo. A essas concepçóes se opôs Capistrano de Abreu, ressaltando a violência dos bandeirantes, o seu confronto ofensivo com as reduçôes religiosas e a escravização dos índios. No período aqui abordado, vale mencionar a obra de Alcântara Machado, Vida e Morte Bandeirante, de I929, que relativizou o mito ao verificar que os bandeirantes eram simples lavradores, mercadores e aventureiros que capturavam índios. "Bandeirantes", em Ronaldo Vainfas (org.), Dicionário do Brasil Colonial (1500-1808). Por outro lado, também desse período, a retomada da imagem conquistadora do bandeirante de Cassiano Ricardo, que figura como "essência e do destino da brasilidade" contra as influências estrangeiras. Segundo ele: "bandeirante no apelo às origens brasileiras; na defesa de nossas fronteiras [...]; na 'marcha para o oeste' que é também o sinônimo de nosso imperialismo [...]". Apud Marilena Chauí. "O Mito Fundador", O Brasil: Mito Fundador e Sociedade Autoritária, p. 69. A esse respeito, ver também Katia Maria Abud, O Sangue Intimorato e as Nobilissimas Tradições - A Construção de um Simbolo Paulista: o Bandeirante.

45. O Biceps, 20 (I5), I958, p. I.

46. As negociaçôes feitas por Carvalho no Rio de Janeiro com os membros do Conselho Nacional de Educação, entre eles Raul Leitão da Cunha, reitor da Universidade do Brasil, e Carneiro Filipe, consultor da Diretoria Geral; o anteprojeto dos estatutos; o processo decisório a respeito do nome da escola; a eleição do Conselho Deliberativo; a aclamação do diretor e a criação do cargo de vice-diretor; a contribuição de cinco contos de réis de cada um 
dos fundadores; a formaçáo da Congregaçấo com os currículos dos professores sucintamente apresentados.

47. O Biceps, 20 (15), 1958, p. 3.

48. As diferenças nas políticas governamentais de saúde pública são um tema recorrente na historiografia especializada. Sem entrar em minúcias desse debate, podemos apontá-lo aqui: enquanto Oswaldo Cruz era o ícone do "campanhismo" (denominação que remete às campanhas de saúde, mas também militares e eventualmente autoritárias) que lutava contra endemias e epidemias por meio de expedições e intervenções pontuais pelo Brasil afora, havia autoridades higienistas (principalmente em São Paulo, daí a suposta especificidade paulista em matéria de saúde pública) que propunham a educação sanitária e a prevenção em centros de saúde como forma privilegiada de intervenção. A defesa de Oswaldo Cruz e seu "campanhismo" em São Paulo, pelo САрв, pode ser um elemento para intervir nessa discussão com novos dados. Agradeço a Jaime Rodrigues pela contribuição.

49. O Biceps, 20 (15), 1958, p. 5. Ainda em torno da época da fundação, o periódico trazia uma lista dos primeiros vestibulandos da EPM e de suas notas, bem como os nomes dos membros da comissão de avaliação. Descrevia ainda a criação do CAPB, a posse de sua diretoria e a "Quinzena Científica" - primeiro simpósio organizado pela EPM, realizado em 1934 com a presença de médicos e sanitaristas nacionais.

50. A respeito do caráter filantrópico tanto da EPM, quando de sua fundação, como do HSP, ver capítulo II.

5I. O Biceps, 20 (I5), I958, p. Iо. Em destaque, passagem de seu discurso que deixara fortes traços na memória da instituição: "Aí está a Escola Paulista de Medicina - a árvore boa, em boa hora, sob um bom signo, numa boa terra e por boas mãos plantada. Ora dessa árvore já adulta, um galho se cortou e para aqui neste instante, se transplanta. É essa estaca inicial do Hospital São Paulo, que agora aqui vai ser batida".
Nota-se que prevalecem os mesmos elogios recorrentes em outras ocasióes, pondo em evidência os grandes fastos da instituição por meio das atitudes heróicas de alguns homens, em que os aspectos filantrópicos dos fundadores são valorizados ${ }^{50}$. $\mathrm{O}$ tom grandiloqüente das matérias, porém, não retira da edição seu caráter informativo, ao oferecer um painel cronológico que se estende até 1958, acrescido de algumas fotografias. Diante do amplo recorte temporal, pareceu necessário aos editores fazer uma seleção temática.

Ao longo dos anos a serem cobertos pelas "reportagens", pode-se perscrutar matérias de fundo institucional e as de fundo acadêmico.

No tocante à do primeiro tipo, ressalta-se a viagem de Carvalho ao Rio de Janeiro, em I935, a fim de tratar da inspeção preliminar concedida após a manifestação favorável e unânime dos membros do CNE. Em linha cronológica, destacam a abertura do Pavilhão Maria Thereza de Azevedo e a cerimônia de lançamento da pedra fundamental do HSP, na qual discursou o poeta Guilherme de Almeidas'. Em I940, a atenção ia para a cerimônia de inauguração parcial do HSP, em cuja matéria o "espírito paulista" ganha novamente espaço ${ }^{52}$. Seguiam-se o reconhecimento, em 1942, da Escola de Enfermagem, tida como "a primeira escola de enfermagem de alto padrão no estado paulista”, e o agradecimento emanado da diretoria da Faculdade de Medicina da Universidade do Brasil, no Rio de Janeiro, e dirigido em I 949 ao Legislativo Federal por ocasião dos debates que redundaram na doação de 28 milhóes de cruzeiros, por parte da União, para saldar as dívidas do "notável estabelecimento" que era a EPM ${ }^{53}$.

Finalmente, as questóes mais sensíveis atinentes ao funcionamento da Escola foram mencionadas timidamente na edição. Um resumo do discurso de Álvaro Guimarães quando Horácio Lafer recebia seu grau de doutor honoris causa, explicava o deficit ${ }^{54}$. Os eventos do ano de I95 I foram condensados no artigo "Realização de um Sonho", cujo texto basicamente resume o já mencionado opúsculo Escola Paulista de Medicina ${ }^{55}$. O leitor obtém uma rápida idéia do que era e de como funcionava a Escola naquele ano: os cursos, sua organização, os órgãos institucionais etc. Nessa descrição, vale frisar o comentário final, mais uma breve alusão à idéia de excelência: apesar das dificuldades financeiras, a Escola lograva formar profissionais bem preparados, auto-intitulando-se a melhor do estado ${ }^{56}$.

A notícia da federalização, momento crucial na vida da instituição, que deixa de ser privada e "paulista" para tornar-se pública e federal, foi veiculada pela publicação de um discurso de Pacheco e Silva. Antes de chegar aos argumentos que explicam a mudança institucional, ele 
insere novamente uma passagem de sua aula inaugural, em que, não fortuitamente, resgata o tema recorrente da especificidade e grandiosidade do "paulista". No contexto da fundação da EPM, credita a ela longevidade, que se manifestará na "série indefinida de lições [...] que irão [...] anos em fora". Essa forte confiança no êxito do empreendimento, que atravessará geraçôes e geraçóes, se justifica por ele nascer "em São Paulo, nesta amada terra nossa, onde tudo cresce, vive e prospera. Descrer seria negar as virtudes da raça. Jamais aqui fracassou empresa, por mais grandiosa e temerária que parecesse à primeira vista, quando firmada em bases seguras" 57 .

Para o palestrante, os autores do projeto inicial integravam um "grupo de paulistas, gente heróica que não sabe viver sem rasgar cada dia novos horizontes [...]", reconhecendo ainda o apoio e a solidariedade de "irmãos de outros Estados", "brasileiros" como "nós" que se identificavam com a iniciativa da fundação da Escola. Com a federalização, "mercê a Deus", a vida da Escola estaria "para sempre assegurada". A partir desse momento, os "dias difíceis" e as "graves apreensóes" tornavam-se lembranças do passado e os "sacrifícios" seriam compensados. O trabalho poderia ser conduzido de forma tranqüila, sem a "angústia da expectativa do futuro, sem a insegurança que durante longos anos passou sobre as nossas cabeças, sem as ameaças de um colapso financeiro" que acabaria enterrando a obra de anos. A federalização era apresentada como único caminho para garantir a manutenção da qualidade do ensino, evitar o aumento abusivo das mensalidades bem como o sucateamento da instituição. O governo, "interessado em manter o ensino superior em elevado nível” e ciente dos limites financeiros do ensino médico privado, tornava-se um parceiro capaz de incrementar os laboratórios e equipar o hospital ${ }^{58}$.

Quanto às notícias de fundo acadêmico, estas se dividiram entre relatos de visitas de renomados professores de outras instituiçôes que proferiram palestras na EPM desde $1933^{59}$, matérias sobre assuntos médicos e de saúde pública, informaçôes acerca das caravanas de estudos dos alunos da EPM, bem como das diferentes atividades do CAPB, incluindo notícias de cunho esportivo. Parte da edição voltava-se à atualidade, como no artigo inventariando o patrimônio material da EPM, ressaltando as instalaçóes modernas e avançadas, tanto do Hospital como das demais dependências técnicas ${ }^{60}$.

Nesse número d'O Bíceps, o Centro Acadêmico questionou as razões pelas quais a diretoria da Escola não se empenhou na organização das festividades em homenagem ao jubileu de prata. $\mathrm{O}$ desconforto era evidente, sobretudo considerando-se que o diretor, José Maria de Frei-
52. Diante do projeto a ser executado, a matéria evoca novamente o espírito paulista: “[...] o hospital que vai ser inaugurado, não pode deixar de ser um atestado eloqüente do dinamismo e do espírito empreendedor de um grupo de paulistas”. "Um Empreendimento Notável: o Hospital São Paulo”, idem, p. I I.

53. "Os Diretores da Faculdade de Medicina Aplaudem", idem, p. I5. Uma breve matéria ressaltou a entrega do grau de doutor honoris causa ao deputado Horácio Lafer, pelo seu empenho no Congresso Nacional para que o projeto de lei que visava saldar a dívida da EPM junto à CEF fosse aprovado, cf. capítulo II.

54. O maior gasto teria sido com o HSP, que desde a sua inauguração até aquela data fornecera 372766 leitos e 306532 consultas para “indigentes”, fazendo jus à vocação assistencialista da instituiçãa. Embora parte desses serviços tenha sido paga por meio de doaçôes e subvençôes, a Escola acabou sendo onerada. Os valores dos gastos e das dívidas são expostas ao leitor. Diante das dificuldades, Guimarães indagava de onde tirar o dinheiro e afirmava que a solução não era diminuir a qualidade do ensino. O diretor ainda sublinhou que a Escola praticamente funcionava graças aos esforços de particulares. Foram poucas as subvençôes do município, do estado ou da União. O pagamento da dívida com a CEF, gerada sobretudo pela construção do HSP, teria "equilibrado por ora suas finanças". "Equilibramo-nos Financeiramente”, O Bíceps, 20 (I5), I958, p. I6.

55. Escola Paulista de Medicina, Fundada em I de Junho de 1933.

56. "Realização de um Sonho", $O B i$ ceps, 20 (I5), I958, p. I6.

57. "Federalizada a EPM! Após Vários Anos de Luta, Conseguida a Vitória [...]", idem, ibidem.

58. Idem, ibidem. As palavras de Pacheco e Silva, datadas de 4 de maio de I957, deixam entrever que a federalização não foi um processo sem oposição, desconfiança e rejeição no interior da própria Escola, expondo claramente o quanto o empenho do diretor José Maria de Frei- 
tas, com o apoio de Otto Bier, foram essenciais para sua concretização. Salienta que a federalização se fez "sem quebra de nossos princípios, sem a alienação dos propósitos de seus fundadores, respeitados todos os direitos do corpo docente, discente e dos funcionários [...]”. A partir dali, conforme afirmava o representante do MEC, a EPM ingressaria no "seio das demais escolas superiores da República”. Para o governo, isso seria uma honra e um orgulho, dada a qualidade da Escola, que figurava como um legítimo padrão para o ensino médico.

59. Várias conferências com "personalidades de renome no meio médico brasileiro" foram realizadas, entre eles Heitor Annes Dias e Roberto Duque Estrada. $\mathrm{O}$ primeiro era o médico brasileiro que empresta seu nome ao Instituto de $\mathrm{Nu}$ trição da prefeitura do Rio de Janeiro, cf. http://www.saude.rio.rj.gov.br/cgi/ public/cgilua.exe/web/templates/htm/ v2/view.htm?infoid=6r I \&editionsectio nid=39, acesso em I6 maio 2007. Sobre sua produção científica, ver Revista da Associação Médica Brasileira, disponível em http://www.scielo.br/scielo.php?script=sci_ arttext\&pid=SoI04-4230200300020002 8 \&lng=pt\&nrm=iso\&tlng=pt, acesso em I6 maio 2007. Dados biográficos estão disponíveis em http://www.saude.rio.rj.gov.br/servidor/cgi/public/cgilua.exe/web/templates/htm/v2/printerview.htm? user=reader \&infoid=I066\&e ditionsectionid=7 I, acesso em I6 maio 2007. Sobre Duque Estrada, cf. http:// tiosam.com/?q=Roberto_Duque_Estrada, acesso em I6 maio 2007. Para uma relação dos conferencistas, ver processo 59, Arquivo da Prograd.

6o. "25 Anos de Escola Paulista de Medicina”, O Biceps, 20 (I5), I958, p. 32.

6I. "Omissão Imperdoável", idem, ibidem.

62. Paulo Mangabeira Albernaz nasceu em Bagé (RS) em I896. Estudou na Faculdade de Medicina em Salvador, especializando-se em otorrinolaringologia. Contribuiu para a pesquisa médica com estudos inéditos sobre a leishmaniose nasal. Depois de ter morado em Campinas, onde criou o Serviço de Otorrinolaringologia da Santa Casa, mudou-se tas, era um dos fundadores, e que no aniversário de dez anos não foram poupadas honras aos que ergueram o "colosso" EPM. Já na efeméride de 25 anos, coube aos alunos e ao СAРB a iniciativa e o encargo da homenagem, promovendo, entre outros eventos, a série de conferências intitulada "Comemoraçóes do Jubileu de Prata" e um coquetel em homenagem aos presidentes do Centro. A falta da auto-celebração institucional era compreendida como uma ruptura da tradição, indicando a importância da realização dos festejos para a percepção e a construçáo da memória institucional: "Hoje, a tradição jaz em abandono. Desprezo? Preferimos, embora com mágoa, atribuí-lo a uma omissão. Imperdoável porém. Porque é a mostra maior que não só entre os alunos campeia o indiferentismo. O exemplo vem de cima" ${ }^{61}$.

Omissão ou indiferença, o fato é que não há notícia de comemoraçóes organizadas pela Escola naquela data. Como já comentado, a incumbência dada a Albernaz pelo CTA de escrever uma história da EPM não se concretizou naquele ano. Notícia Histórica dos Primeiros 25 Anos foi publicado somente uma década mais tarde. $\mathrm{E}$, ao contrário do que pretendia a ediçáo de jubileu dos 25 anos d'O Bíceps, trata-se de um livro que traz "o simples desfilar de fatos históricos", baseado nas atas institucionais da EPM.

No prefácio de sua obra, Albernaz alerta para a dificuldade de se "escrever história", acentuada pelo fato de ele ter sido um dos participantes da "grande aventura" de erguer a EPM, o que a tornava "parte integrante" de sua vida ${ }^{62}$. Assim, justifica ser-lhe a imparcialidade impossível. No entanto, crê em seu "espírito de justiça", que permite narrar os fatos desses anos, dos quais foi testemunha tal como são descritos nas atas. Ele pretendia mostrar a "realidade" por meio do cotejo rigoroso e imparcial desses documentos, sem se distanciar do espírito crítico, pois ele nada teria de destruidor. Enquanto sugere que essa história resulta de uma "caminhada corajosa" através do tempo, Albernaz a compara com o destino da própria EPM: uma jornada de glória ${ }^{63}$.

No capítulo "Os Primeiros Passos", Albernaz recupera os momentos decisivos para a criação da EPM, ao qual anexa, sem qualquer comentário, o Manifesto de Fundação da EPM e a lista dos subscritores. Ao longo da obra, em que cada ano corresponde a um capítulo, a história da instituição segue um eixo cronológico apresentando uma sucessão dos fatos e acontecimentos - uma história factual a partir de fontes únicas, produzidas oficialmente na instituição. As atas, nesse caso, tornam-se portadoras da realidade, conferindo a elas o status de documento histórico, tal qual a receita historiográfica positivista pres- 
crevia, segundo a qual os documentos "oficiais" são as únicas fontes autorizadas que levam ao conhecimento da verdade histórica.

Trata-se de uma descrição dos acontecimentos a partir dessa documentação, com poucas análises e interpretaçôes. Os fastos, bem como as dificuldades, são mencionados sem maior reflexão e tampouco indicaçóes bibliográficas precisas. Apesar de "enfadonha", conforme o próprio autor a adjetivou, a obra tem seu mérito por justamente ter nascido a partir das atas e com isso revelar uma série de informaçóes institucionais comumente inacessíveis (especialmente antes da era digital). Um cotejo sistemático entre as atas e o livro poderia apontar as escolhas, as omissóes e as preferências temáticas do autor. Mas isso ultrapassaria a proposta do presente ensaio, cuja questão é analisar as concepçôes da história institucional da EPM. O que aqui vale frisar é o fato de o autor se basear mormente nessas atas, sem em momento algum refletir acerca da natureza e das características desses documentos que o autorizam a escrever uma história "verdadeira”. Em outras palavras, Albernaz acreditava no que leu e vivenciou, considerando a leitura e a vivência como suficientes para narrar ao leitor a história de como as coisas tinham acontecido.

Em suas "Palavras Finais", ele afirmou que a Escola, "partindo do nada, foi, paulatina e gradualmente, mas sem esmorecimento, realizando uma das façanhas mais admiráveis, mais espantosas do ensino superior em nosso país". Reiterava o quanto fora conseguido pelo próprio esforço, superando as deficiências de instalaçóes e equipamentos, produzindo o que "institutos oficiais jamais chegaram a produzir". Apontou as especificidades que a conduziam aos "acmes mais elevados [sic] do ensino médico nacional": a originalidade na organização dos departamentos médicos, como os de Clínica Médica e Clínica Cirúrgica e em especial o de Ciências Biológicas, o pioneirismo dos testes gerais e testes de inteligência na prática dos exames de habilitação; a construção do primeiro hospital de clínicas no país. Estes seriam alguns dos elementos do "mais alto padrão técnico, aprovados, elogiados e admitidos, para uso oficial, pelo próprio Conselho Nacional de Educação e pelo Ministério de Educação. Isto fez da Escola Paulista de Medicina, conquanto faculdade particular, um instituto padrão no ensino médico" ${ }^{64}$.

Albernaz eliminava no leitor qualquer dúvida de que sua obra era um panegírico da ЕPM ou uma epopéia. Sua apreciação elogiosa acerca da história da Escola era apresentada como fruto dos fatos e de sua conduta auto-crítica e prenhe de "espírito de justiça”. "Não são palavras vâs", avisava. O autor despediu-se, deixando transparecer certa para São Paulo. Em 1933, assinou o Manifesto de Fundação da EPM, instituição na qual fez sua carreira docente. Em homenagem ao seu empenho na organização de congressos e pela dedicação à pesquisa, foi agraciado com a Comenda de Grande Oficial da Ordem do Mérito Médico, recebida das mãos do presidente Castelo Branco em 1966, entre outros prêmios que lhe foram conferidos. Um deles, o prêmio "Eliseu Segura" em El Salvador, pelo seu desempenho a favor da aproximaçấo do conhecimento entre os países latino-americanos no campo da otorrinolaringologia. Morreu em 1982. Angelo Mazza, "Paulo Mangabeira Albernaz”, em José Ribeiro do Valle, op. cit., pp. I38-I4I.

63. Paulo Mangabeira Albernaz, "Prefácio", op. cit.

64. Idem, p. 22I. 
65. Idem, p. 222.

66. A Universidade Federal de São Paulo aglutinaria a EPM, a Escola de Engenharia de São Carlos da usp, Faculdade de Filosofia, Ciências e Letras de Araraquara, Faculdade de Farmácia e Odontologia de Araçatuba e Faculdade de Ciências Econômicas de Santo André. Em outubro de I964, a EPM foi desligada da Universidade Federal por meio da lei nº 4.42I, disponível em http://www6. senado.gov.br/legislacao/ListaPublicacoes.action?id=II5088, acesso em jan. 2008. Para mais detalhes, ver capítulos III e iv.

67. "Universidade da Escola Paulista de Medicina que Está Comemorando o seu $30^{\circ}$ Aniversário", A Gazeta, 9 set. 1963. Além deste jornal, os trinta anos da EPM foram notícia n'O Estado de S. Paulo e na Folha de S. Paulo. melancolia ao mencionar a mudança geracional em curso. A EPM era um "templo sagrado", monumento do qual seus "operários" se viam obrigados a se afastar, tristemente. Mas logo o autor se mostrava esperançoso, ao sublinhar que a entrega do bastão far-se-ia a sucessores bem preparados, discípulos que assumiriam os desafios em condiçóes mais propícias que os fundadores. Em um quarto do século, criaram uma instituição, "erguerem-na aos píncaros, e deixaram sucessores capazes de ainda mais alto a elevarem". Eis o seu maior "galardão", conclui $^{65}$. O tom grandiloqüente de sua narrativa faz dela um profícuo exemplo de uma história heróica. Nela, enfatizam-se a pobreza e precariedade iniciais, a batalha e a determinação para vencer e superar as dificuldades, bem como a excelência atingida, sempre numa caminhada certeira e solitária.

\section{Trinta Anos de ерм e a Primeira Celebração como Universidade}

Em seu $30^{\circ}$ ano a EPM, além de federalizada, era parte integrante da recém-criada e institucionalmente frágil Universidade Federal de São Paulo (UFSP), implantada em I 960 e abortada em I964, logo no início da ditadura militar ${ }^{66}$. Quando das comemoraçôes desse aniversário, Marcos Lindenberg era o diretor da EPM e reitor da UFSP.

Ao contrário das efemérides anteriores, os festejos deste aniversário incluíram um programa diversificado de atividades, cujo fim era reunir toda a "família que edificou a EPM - fundadores, professores, assistentes, alunos, auxiliares e amigos" ${ }^{67}$ (Figura 6). As comemoraçôes dividiram-se em competiçôes esportivas, inauguraçôes, palestras, atividades culturais e sessóes solenes conduzidas pelo Centro Acadêmico, pela Associação Paulista de Medicina, pela Associação dos Ex-Alunos da EPM e pela Congregação.

Em 9 de setembro de I963, primeiro dia das comemoraçóes, inaugurou-se o busto em homenagem a Octávio de Carvalho, implantado no pátio interno da EPM e esculpido por Lindenberg. O homenageado estava presente, proferindo algumas palavras sobre as origens da Escola e mencionando as dificuldades em torno de sua "ascensão" e "declínio" na condição de fundador e diretor. Lembrou o quanto se empenhara em persuadir os membros do CNE a reconhecerem a EPM. Na época, o Conselho compunha-se de membros contrários à criação de escolas médicas livres. Seu afastamento da direção da EPM, em I938, foi por ele interpretado como decorrência do entrechoque das ambiçóes e da "fermentaçãa" no seio da Congregação, abreviando seus projetos e fazendo-o deixar "inacabada [...] tão promissora realização". Com ironia, 
UIIVERSIDADE FEDERAL DE SÃO PAULO

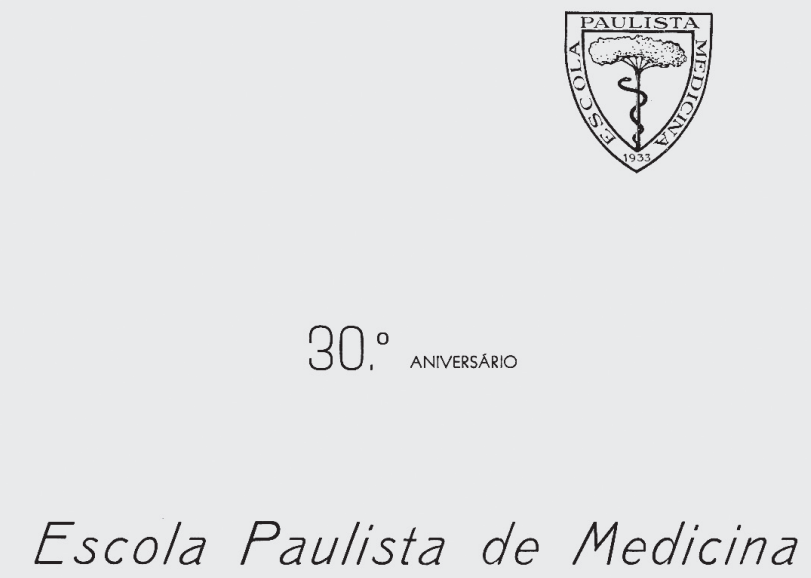

Escola Paulista de Medicina

SeTEmBro de 1963

FIgURA 6. Programa das comemoraçóes do $30^{\circ}$ Aniversário da EPM-Universidade Federal de São Paulo. Fonte: Acervo cenfi, pasta nº 3-Aniversário - 30 anos da EPM, documento 4.

reflete sobre a própria homenagem: "Os monumentos comemorativos são quase sempre póstumos. Poucos têm sido os criadores que tiveram a ventura de assistir em vida a sua própria consagraçáo, como reparaçáo e reconhecimento dos erros, injustiças e incompreensôes dos contemporâneos". Um desabafo final expressava seu desapontamento:

Se tive a felicidade [...] de ver realizado na velhice, um sonho de mocidade, muito embora entrecortado de lutas sem conta e de uma longa noite de angústias e pesadelos, que durou quase metade de minha vida, ainda me restou, apesar dos pesares, o conforto de ver consubstanciado no monumento imorredouro, que será um marco na história da arte moderna ${ }^{68}$.

Se não se tornou marco da arte moderna, o busto certamente marcou a EPM e o próprio Carvalho (Figura 7).

68. Octávio de Carvalho, História da Escola Paulista de Medicina: Curriculum Vitae, p. 27. 


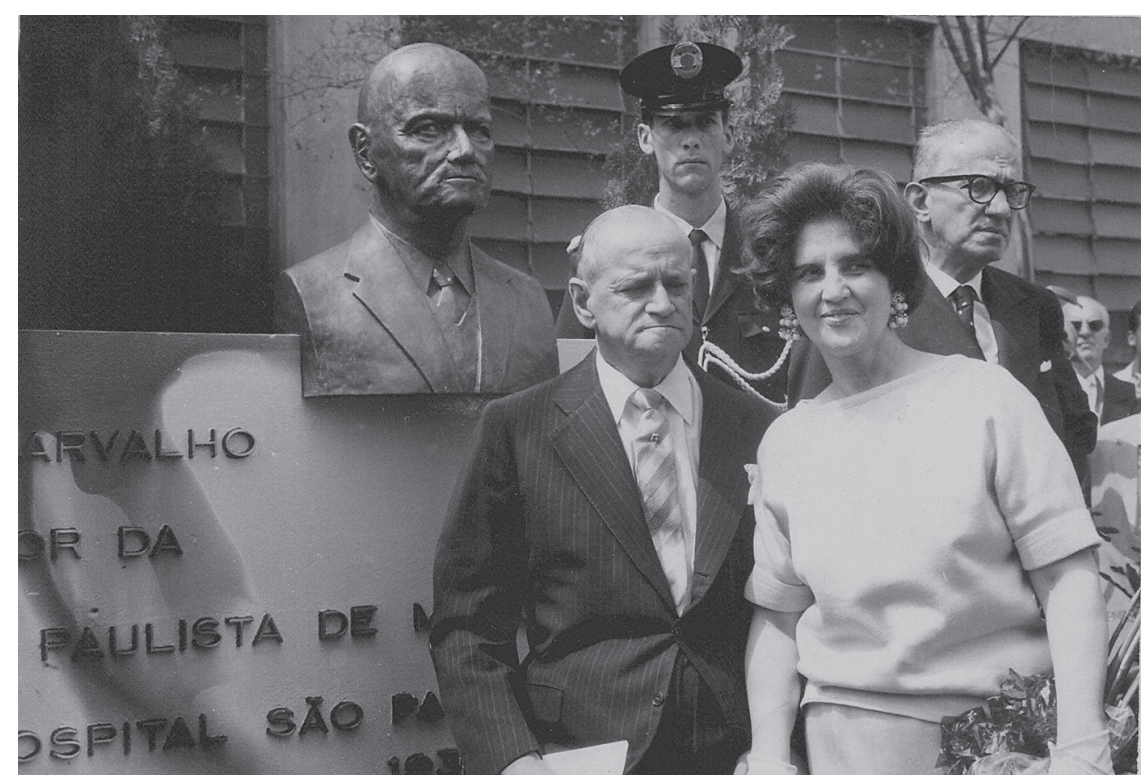

Figura 7. Octávio de Carvalho e esposa diante do busto esculpido por Marcos Lindenberg.

Nessa efeméride, foram poucas as palestras, entre elas a proferida por Lindenberg na Associação Paulista de Medicina e intitulada "Educação Médica”. As atividades culturais incluíram uma exposição de arte no saguão da biblioteca, com cerca de cinqüenta fotografias, esculturas e pinturas feitas por alunos, médicos ex-alunos, residentes e assistentes da EPM, concorrendo a uma premiação oferecida pelo CAPB. Uma conferência do arquiteto Eduardo Kneese de Melo sobre Aleijadinho e Niemeyer e a pré-estréia do filme japonês Amor e Tristeza completaram a agenda ${ }^{69}$.

Também foram entregues novas instalações, como as do Instituto de Biologia da Universidade Federal, o lançamento da pedra fundamental do edifício de Ambulatórios e do Departamento de Educação Cívica e Física - eventos sempre muito concorridos para autoridades ou seus representantes ${ }^{70}$. A cerimônia foi seguida de almoço e missa em

69. "Mostra Pictórica nas Comemoraçóes da EPM", Folha de S. Paulo, p. I6. "A ерм Iniciou os Festejos do $30^{\circ}$ Aniversário", idem, p. 17.

70. Nos Ambulatórios, estavam presentes o representante do prefeito, Ariovaldo de Carvalho (à época secretário da Higiene), o engenheiro Renato Mesquita (da Divisão de Obras do MEc) e o representante do governador de São Paulo, Adhemar de Barros. ação de graças. No Instituto de Biologia, foi o representante do ministro da Educaçáo quem descerrou a placa inaugural, enquanto o catedrático de Microbiologia da EPM, Otto Bier, proferiu um discurso cujo otimismo repousava na observaçáo de que o Brasil estaria "decidido de romper os grilhóes que ainda o prendem ao subdesenvolvimento". Entusiasmado, considerava que nada poderia impedir o processo de industrialização e da conseqüente renovação dos métodos da produção agrícola. Tal desenvolvimento, assim sugere, implicaria uma "modificação profunda em nossa estrutura social e que a Universidade terá de 
adaptar-se a esse novo equilíbrio social”. Sem dúvida, as concepçôes nacional-desenvolvimentistas haviam tocado o palestrante ${ }^{71}$.

A inauguração do Instituto de Biologia (Figura 8) era interpretada como marco da integração da EPM na UFSP - uma universidade, que, segundo Bier,

[...] nasce sob os auspícios de um país em busca de emancipação, de uma universidade que se destina de ser grande e sólida [...], que crescerá de dentro para fora, sem hipertrofias balofas; de uma universidade que aspira a prestar serviços, abrindo maiores perspectivas aos jovens brasileiros, cônscia dos deveres para com a comunidade que contribui para a sua manutenção ${ }^{72}$.

A "Escolinha" - alcunha pejorativa inventada logo após a fundação em 1933 pela Faculdade de Medicina, que se gabava pelas suas modernas instalaçóes, e que a própria EPM incorporou e transformou em apelido afetuoso ${ }^{73}$ - assumia publicamente que sua identidade fora absorvida, ainda que não diluída, num corpo maior, numa universidade espalhada em várias unidades pelo Estado de São Paulo.

$\mathrm{Na}$ sessão solene da Congregação, em I4 de setembro, realizada no recém-inaugurado Instituto de Biologia da UFsP, José Ignácio Lobo ${ }^{74}$ exaltou o papel da EPM no ensino da medicina preventiva e citou os congressos em Viña del Mar (Chile) de I955, o primeiro e o segundo congressos da Associação Médica Brasileira, em Ribeirão Preto (1956) e em Belo Horizonte (I959), dos quais a Escola orgulhosamente participou na reforma do ensino médico no país, elaborado pelo então ministro Clóvis Salgado, que incluía a extensão do sistema departamental. A EPM prontamente adotou as mudanças sugeridas, introduzindo o Departamento de Higiene e Medicina Preventiva, o que assumiu "o aspecto de verdadeira inovação, por conjugar sua atividade com diversas outras cátedras, estendendo a sua esfera de ação até fora da Escola”. A reforma também previu novas formas de aplicação dos vestibulares, ensino de clínica médica no quarto ano no regime de clerkship $^{75}$ (noviciado), integração dos cursos de propedêutica e clínica médica e cirúrgica. Além disso, menciona a organização do ensino de clínica médica em ambulatório, integrado com a cadeira de Higiene e Medicina Preventiva, tendo em vista a assistência e edição do paciente no domicílio; a introdução do ensino de psicologia, "para que o aluno não descuide do lado humano do doente de que cuida" e, por fim, a observância, pelos docentes de clínicas, do regime de tempo integral "geográfico", graças ao qual os professores e assistentes permanecem o dia todo junto às enfermarias e ambulatórios. Lobo chamou atenção para o fato de que
7I. "Inauguração e Pedra Fundamental na Festa de Aniversário", Folha de S. Paulo, I5 set. 1963, p. I2.

72. Idem, ibidem.

73. Álvaro N. Atallah, Regina C. R. Stella e Ulysses Fagundes Neto, op. cit., p. I83.

74. Chefe da equipe de pesquisa clínica em endocrinologia da EPM nos anos de I940, sócio-fundador da Regional de Sáo Paulo da Sociedade Brasileira de Endocrinologia e Metabologia em 1954 e chefe da Seção de Endocrinologia do Departamento de Clínica Médica da ерм em I955. Cf. http://www.endocrino.org.br/conteudo/sociedade/diretoria_004.php, http://www.unifesp.br/ dmed/discipl2.htm e http://www.unifesp.br/dmed/consolid.htm, acesso em jan. 2008.

75. O clerkship ou noviciado era a base do ensino da clínica médica e antecipava o internato e a residência. Desenvolvia-se sob direção única, com chefe do departamento, e era realizado ao longo de três anos, iniciando-se na terceira série do curso de graduação. No quarto ano, o aluno estagiava em cardiologia, pulmonologia, nutrição, nefrologia e pediatria. O clerkship era feito em enfermaria geral. De preferência, deveria haver número suficiente de leitos para cada turma. Para mais detalhes, ver Durval Rosa Borges et al., "Histórico da Formação Médica na Escola Paulista de Medicina e suas Perspectivas na Universidade Federal de São Paulo", em Rosana Fiorini Puccini, Lucia de Oliveira Sampaio e Nildo Alves Batista (orgs.), A Formação Médica na Unifesp: Excelência e Compromisso Social. 


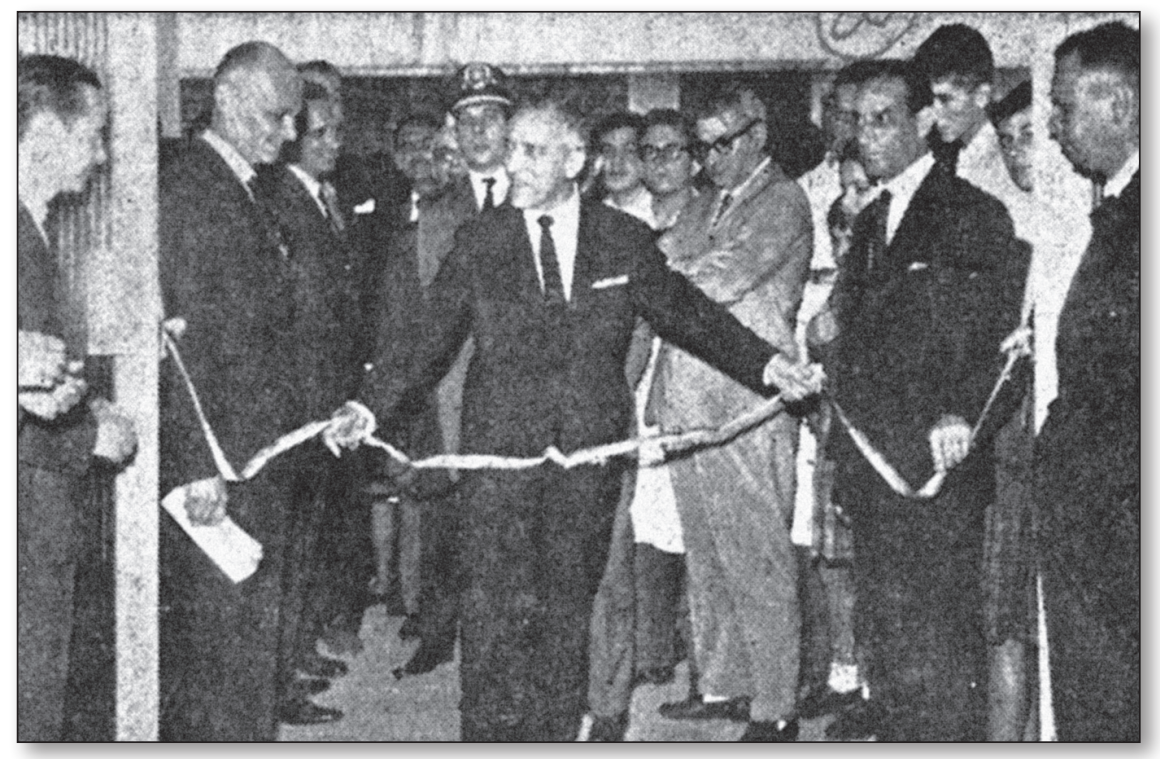

Figura 8. Ariovaldo de Carvalho, secretário da Higiene, corta a fita simbólica inaugurando o Instituto de Biologia da Universidade Federal de São Paulo. À sua esquerda, Marcos Lindenberg. "Inauguração e Pedra Fundamental na Festa de Aniversário". Folha de S. Paulo, I 5 set. I963, p. I 2.

essas reformas reiteravam o auxílio oriundo da Fundação Rockefeller. Após esse breve relato das mudanças, advertiu que elas não deviam ser compreendidas como "simples registro histórico, nem tão pouco [sic] como panegírico", mas sim "expressão do pensamento desta Escola sobre o magno problema da educação médica" ${ }^{76}$.

Depois de pontuar o que houve de inovador na EPM, lembrou qual seria o objetivo maior de uma escola: ensinar a estudar, a observar e a criticar e jamais esgotar uma matéria. Sua função seria desenvolver a capacidade de análise, de trabalho em grupo e de discussão objetiva dos fatos e dos textos, de sua interpretação, tendo como perspectiva a realização da pesquisa. Nesse sentido, a EPM estaria conciliando de forma harmônica o ensino, a pesquisa e a assistência. Lobo refletiu sobre a história institucional da EPM apenas sete anos após a federalização. Enfatizou que o passado provara a "capacidade da iniciativa privada em matéria de criação e organização do ensino superior numa das mais complexas modalidades, o ensino médico". As dificuldades financeiras explicavam-se pelo funcionamento em si oneroso da natureza da disciplina, de sua prática e da assistência gratuita, e "exclusivamente estas,

76. José Ignácio Lobo, A Gazeta. Mimeo., s./l., s./d., p. 3. Acervo do сенғi, pasta no 3 -Aniversário - 30 anos da EPM. obrigaram-na a situar-se dentro da administração pública”. Transpirando insatisfação com os rumos inevitáveis dos acontecimentos, conclui 
que a "federalização encontrou obra feita, claro que não completa", após a Escola ter vivido 23 anos "por seus próprios meios" 77.

Em meio aos festejos marcados pelo processo de mudança na identidade da EPM, agora parte da UFSP, não se aventava que essa condição seria tão efêmera. Após o golpe militar de I964, a EPM não somente foi desligada da UFSP, mas instalou-se um Inquérito Policial-Militar (IPM) dentro da Escola. O então ex-diretor da EPM, ex-reitor da extinta UFSP e professor catedrático Marcos Lindenberg seria cassado. Não estava sozinho: outros colegas e alunos, entre eles Walter Albertoni, estavam na lista dos que sofreram perseguiçóes ${ }^{78}$.

\section{A epm Faz Quarenta Anos}

A comemoração dos quarenta anos da EPM ocorreu no momento mais difícil da ditadura. A formação da comissão executiva dos festejos, presidida pelo ex-aluno e, na época, deputado Fauze Carlos (Arena), dá uma amostra da importância do evento. Criaram-se várias comissões e subcomissóes: do jantar de confraternização, de programação científica, do culto ecumênico, do coral, direção do show, de programação esportiva, de divulgação e redação - integrando aproximadamente 32 pessoas, entre professores e alunos, além de um assessor de relaçôes públicas. A programação contou com o apoio de empresas ${ }^{79}$ e pretendia reunir grande parte dos cerca de três mil egressos da EPM. Contava-se com a presença do corpo docente, professores, alunos e autoridades, entre elas o ministro da Educação, Jarbas Passarinho ${ }^{80}$.

A programação estendeu-se de I 5 a 23 de junho de I973. Mantendo a tradição de comemoraçóes anteriores, contemplavam-se atividades sociais $^{81}$, científicas $^{82}$ e esportivas $^{83}$. Uma sessão solene no plenário da Assembléia Legislativa abriu a semana de festejos. O presidente da Assembléia, deputado José Julianelli ${ }^{84}$, iniciou a solenidade e passou a palavra ao ministro Passarinho, seguindo-se as falas de Horácio Kneese de Mello, diretor da EPM, e de Fauze Carlos, ex-secretário da Saúde do Estado.

Em 20 de junho de I973, José Ribeiro do Valle, da comissão executiva, proferiu discurso comemorativo no jantar-dançante de confraternização. As palavras pareciam ser amenas, vindas do "coração" e não da "razão", em sintonia com o propósito do evento, mas acabaram tocando em pontos sensíveis pelos quais a EPM estaria passando. A evocação do passado não podia faltar, já que Valle integrou a primeira leva dos professores contratados pela "Escolinha", em I934, com o apoio de Otto Bier e André Dreyfus. Os tempos da fundação foram associados ao "entusiasmo contagiante" e ao "ambiente de idealismo

\footnotetext{
77. Idem, ibidem.

78. Ver capítulo III.

79. McCann Erickson Publicidade, Turismo Real e do Banco Real.

8o. "Mensagem ao Ex-Aluno", Boletim Informativo EPM 40 anos, Is a 23 jun. I973, s./p. Acervo do сенғi, pasta nº I 4 - Aniversário: 40 e 60 anos da EPM.
}

8I. As atividades sociais incluíram um culto ecumênico, o lançamento da pedra fundamental da praça de esportes, um jantar dançante de confraternização no Clube Atlético Monte Líbano acompanhado de um show com acadêmicos da EPM, e um programa social e turístico para os familiares dos ex-alunos.

82. A programação científica concentrou-se num simpósio de seis dias, intitulado "Progressos da Medicina". Participaram do evento por volta de 69 expositores, divididos em mesas de quatro a cinco participantes. A conferência inaugural foi incumbida a Roberto Santos, presidente do Conselho Federal de Educação. $\mathrm{O}$ que chama a atenção na grande quantidade de participantes é o número exíguo de mulheres. Afora a mesa da enfermagem, poucas médicas apresentaram trabalho-apenas quatro, além das cinco que compuseram a mesa de enfermeiras.

83. Foram realizados jogos e competições de futebol, tênis, atletismo e voleibol masculino e feminino entre alunos e ex-alunos da EPM.

84. Ver supra, nota 28. 
85. "Concretizada ou não a estrutura maior, a EPM continuará suas atividades universitárias em futuros institutos de Matemática, de Biologia, de Física e de Química, e no complexo das ciências humanas e da saúde. Os nossos centros indutores já operantes apenas aguardam o cimento aglutinador e o estímulo vivificante de uma instituição universitária bem planejada”. José Ribeiro do Valle, “40ํㅡㄹ Aniversário da EPм", A Escola Paulista de Medicina: Dados Comemorativos de seu 40 Aniversário (1933-1973), p. 365. Sabemos que durante a gestáo Passarinho (1969-1974) houve a elaboração de um projeto de lei visando a transformação da EPM em uma universidade de ciências biológicas e da saúde. No entanto, o projeto foi rejeitado por parecer de Leitão de Abreu, secretário da presidência da República no governo Geisel, que defendia a idéia da universalidade do conhecimento como critério para a concretização de uma universidade. Cf. Ana L. Guímaro e Leonel Prata (eds.), A Universidade da Saúde: Escola Paulista de Medicina, 70 Anos, pp. 59-6o, e o capítulo Iv deste livro. Note-se que, nas palavras de Valle, as ciências humanas são mencionadas no complexo universitário - diferentemente, portanto, do projeto de uma universidade temática.

86. Jair Xavier Guimarães, "A Escola que Eu Vi Nascer”, Jornal da Associação Médica Brasileira, I5 (653), 5 jun. 1973. sadio" em que professores e alunos lutavam pela mesma causa. Nesse clima de lutas e aventuras, Valle relembrou da incipiência dos laboratórios e das enfermarias. "Era a pobreza franciscana de quem começa do nada". Comparando os tempos idos com o presente da EPM em I973, indagou-se: "Como foi possível, Santo Deus, chegar a tanto, partindo de tão pouco?” A resposta ele mesmo buscou na mitologia cultuada na Escola: "Mas isto era São Paulo!", indo ao encontro mais uma vez da imagem do paulista como vencedor. Evocou, então, as personalidades fundadoras: nos primórdios, houve o "entusiasmo empreendedor de Octávio de Carvalho, a segurança de Lemos Torres e a pertinência de Álvaro Guimarães". Agradeceu ainda a todos que de alguma forma haviam contribuído no passado, pois "sem eles, ontem, não seríamos nós, hoje!”, lançando ao mesmo tempo um olhar para a futuro, baseado no que fora feito e vislumbrando uma instituição que "já não pode mais se conter nos limites de uma escola profissional isolada, pois está a exigir, com sobradas razóes, foros de Universidade!" Por fim, referiu-se ao presente: "Ainda há pouco, ouvíamos do Senhor Ministro da Educação [Jarbas Passarinho] que o Governo Federal precisa atender tais reclamos e assim resgatar velha dívida para com São Paulo. Os dados estão lançados”.

Muito provavelmente, ele não se referia à dívida da universidade abortada em I964, pois esta não parecia ter deixado boa lembrança entre os que permaneceram na Escola. A questão em jogo era conseguir expandir-se como universidade a partir do núcleo da EPM. Valle vislumbrava o futuro ${ }^{85}$.

Os quarenta anos da EPM foram assunto de uma edição especial do Jornal da Associação Médica Brasileira. Nela, incluiu-se uma entrevista com Jair Xavier Guimarães, aluno da primeira turma e, mais uma vez, rememorava-se o espírito paulista marcado pelo ambiente pósrevolução de I932: o ressentimento pela derrota do ideal de "restauração da liberdade democrática” opondo-se à sua força e ao seu espírito "inquebráveis" 86 . Guimarães exaltou o orgulho dos paulistas "nativos" e dos imigrantes, sem esquecer dos "irmãos de outros estados”, que desejavam reconstruir, com amor e perseverança, a educação médicohospitalar defasada no estado e na União.

Nota-se a reiteração da história fundadora, em que se contam e recontam as condiçóes daquele início, emprestando-lhe uma aura mítica. A repetição age como gesto de convicção, em que os fatos distantes sejam evocados com o fito de possibilitar uma identificação entre o momento coevo e o passado. É como se o convencimento se desse pela repetição da mesma idéia ad nauseam, e não pelos princípios comparti- 
lhados - provavelmente porque era impossível compartilhar princípios em contextos e tempos tão diferentes quanto a fundação e as efemérides cada vez mais distantes do mito de origem.

As palavras seguintes de Xavier Guimarães iam ao encontro dos argumentos e declaraçóes expressas no Manifesto, mostrando mais uma vez a importância que se atribuía àquela carta de intençóes ${ }^{87}$. Discorreu sobre as dificuldades, a incredulidade de muitos e a resistência de outros, superadas graças ao "sacrifício e à abnegação dos professores fundadores" e à tenacidade de Carvalho ${ }^{88}$. Desde o reconhecimento do curso pelo CNE, "a Escola já firmara conceito, passando a ser considerada e respeitada como instituição particular de ensino [...] que se esmerava em ministrar ensino de bom padrão". É como se, a partir dali, a instituição seguisse sua vocação como um dado natural, obedecendo sempre aos mesmos critérios: "[...] Outras turmas formadas, todas elas trabalhadas e buriladas com o mesmo carinho, a custa de redobrado esforço, sacrifício e abnegação”. Por fim, Guimarães nomeou os professores fundadores, exaltou-os como pioneiros e bem-aventurados por construírem sua obra "com amor" 89.

Mas foi no livro escrito por José Ribeiro do Valle que os quarenta anos da Escola ganharam dimensóes mais abrangentes. Como o livro de Albernaz, este também foi escrito e organizado por punhos epemistas e, igualmente, não veio a lume no ano da efeméride. Tratava-se de obra escrita por um olhar testemunhal e cúmplice de uma EPM "adulta", publicado após quatro anos de "exaustiva busca de dados e informaçôes"9o. $\mathrm{Na}$ "nota liminar", já se evidencia o caráter da obra:

Leio em Antenor Nascentes: Poliantéia - coleção de escritos em prosa ou verso em homenagem a pessoas ilustres ou em comemoração acontecimento célebre. Para nós - professores, alunos, pessoal administrativo e amigos da Escola Paulista de Medicina, as festas comemorativas de seu quadragésimo aniversário (I973) foram acontecimento marcante [sic] a sugerir esta coletânea de biografias de seus fundadores e de outros professores, além de notas e várias lembranças $^{91}$.

Após essa breve introdução seguia-se, mais uma vez sem comentários, o Manifesto de Fundação e a lista dos signatários. Em seguida, transcreveu-se a relação do corpo administrativo e dos funcionários da EPM em I934, que àquela altura contava com cerca de trinta pessoas ${ }^{92}$. $\mathrm{Na}$ lista constam os funcionários técnicos e administrativos, incluindose o guarda-noturno e o porteiro. A contribuição de alguns deles seria tratada com mais detalhes no capítulo "Benfeitores e Colaboradores".
87. Em resumo, Guimarães citou a questão da falta de vagas; o grande número de candidatos; a emigraçấo obrigatória de jovens para outros estados, onerando material e moralmente as famílias; a ausência do atendimento hospitalar para os mais pobres e a filantropia do projeto que se manifestava na fundação de uma sociedade civil sem fins lucrativos. Idem, ibidem.

88. Entre os episódios relevantes, mencionou o empréstimo da CEF para a compra do terreno e mais dez mil contos para a construçáo do hospital, a colaboração "desinteressada" do conde Francisco Matarazzo, o concurso do professor alemão Walter Büngeler para o ensino de anatomia patológica, a concessão de amostras de café feitas pelo Departamento Nacional do Café com a geração de uma renda respeitável para o HSP e, finalmente, o funcionamento reconhecido pelo CNE em 1938. Idem, ibidem.

89. Idem, ibidem.

90. José Ribeiro do Valle, op. cit., p. 377.

9I. Idem, p. x.

92. Idem, pp. XV-XVI. 
93. Morfologia, Anatomia Patológica, Bioquímica e Fisiologia, Bioquímica e Farmacologia, Psicobiologia, Microbiologia e Parasitologia, Medicina Preventiva, Neurologia e Neurocirurgia, Psiquiatria, Tocoginecologia, Pediatria, Medicina, Cirurgia e Educação Física. Além dos departamentos, havia um Serviço de Assessoramento e Apoio Pedagógico. Idem, pp. XXI-XXXII.

94. Idem, p. xxxix.

95. Para Valle, a EPM se fortaleceu institucionalmente graças à administração dos primeiros diretores - Octávio de Carvalho, "espírito empreendedor" e que teve a "idéia desencadeante" da fundação, conforme as palavras de Lemos Torres, o segundo diretor. Este último teria sido um "espírito brilhante de médico e cientista, verdadeiro fundador de uma escola médica em São Paulo" e que projetou a Escola nos meios científicos nacionais e internacionais. Idem, p. XL.

96. Uma das grandes preocupaçóes de Bier naquele momento era arrancar o Brasil do seu "subdesenvolvimento" e da dependência externa. Caberia à universidade formar pesquisadores capazes de desenvolver conhecimento, libertando-se do know-how estrangeiro. Bier sintetizou as novas diretrizes da educação superior - voltada à formação de pesquisadores úteis para a sociedade, que desenvolvessem pesquisa científica e tecnológica para a melhoria de condiçóes da vida humana; uma formação que levasse à difusão da cultura "em qualquer nível" e se comunicasse com o "povo", contribuindo para a "tomada de consciência de problemas nacionais", a formaçấo e a informação da opiniāo pública e que, finalmente, fortalecesse a "paz e solidariedade universal”. Idem, p. XLIII.

97. Afrânio do Amaral (p. II); Alípio Corrêa Netto (p. I6); Álvaro de Lemos Torres (p. 20); Álvaro Guimarães Filho (p. 24); Antônio Bernardes de Oliveira (p. 29); Antônio Carlos Pacheco e Silva (p. 32); Antônio Ferreira de Almeida Júnior (p. 37); Antônio Prudente Meirelles de Moraes (p. 42); Archimede Busacca (p. 46); Carlos da Rocha Fernandes (p. 50); Décio Pereira de Queiroz Telles (p. 53); Domingos Define (p. 57); Dorival
Lista semelhante referia-se ao ano de I976, excluindo, porém, os funcionários administrativos. Atém-se ao alto escalão da EPM e ao corpo docente, vinculados aos respectivos departamentos ${ }^{93}$.

Antes de passar às biografias dos fundadores, Valle escreveu um preâmbulo, narrando uma breve história da EPM. Apresentou, nesse item, a comissão executiva do $40^{\circ}$ aniversário, bem como o programa das atividades científicas. Iniciou panorama histórico da EPM mostrando os desdobramentos sociais representados pelos médicos formados na Escola - cerca de três mil desde a fundação, atuando no mercado de trabalho e "nas principais áreas de liderança comunitária". Nesse sentido, lembrou dos médicos que ingressaram na política, ocupando cargos na Secretaria da Saúde ou como vereadores e deputados.

Em outras palavras, Valle quis mostrar a presença estratégica da EPM tanto na ciência quanto na sociedade e na economia. Sublinhou, por exemplo, a importância da pesquisa farmacológica e bioquímica desenvolvida na Escola, com o objetivo de conseguir a auto-suficiência do Brasil na fabricação de matéria-prima para a indústria farmacêutica, posto que quase todo o material básico era importado ${ }^{94}$. Em seguida, retornou aos idos da fundação. O leitor novamente se depara com uma citação do Manifesto, no qual São Paulo voltava a ser evocado como lugar de "vitalidade espiritual"95.

Depois, discorreu sobre a importância do HSP e fez uma breve descrição do incremento institucional no plano físico, bem como de conteúdos. Antes de finalizar esse item, Valle reproduziu na íntegra o discurso de Otto Bier quando da inauguração do Instituto de Biologia da breve e malograda UFSP, no aniversário dos trinta anos. Para Valle, as palavras de Bier foram proféticas e ainda eram válidas, apesar da década que se passou. Nelas, Bier teceu reflexóes sobre o papel social da universidade e de sua vocação no campo do ensino e da formação ${ }^{96}$. Resta tentar saber por que Valle reproduziu na íntegra o discurso de Bier. Seria uma maneira indireta de resgatar a questáo da EPM como berço de uma universidade moderna, voltada a um "conceito bem diverso daquele que ainda há pouco tempo estatuía a doutrina oficial”, conforme Bier havia sugerido? Em I977, a EPM já teria passado por duas recusas explícitas em se tornar uma universidade.

Ao chegar à poliantéia propriamente dita, Valle apresentou em primeiro lugar as biografias dos 33 signatários do Manifesto de Fundação ${ }^{97}$. Em seguida, foi a vez dos professores catedráticos concursados e dos docentes substitutos, contratados ou interinos, entre I939 a $1964^{98}$. Por fim, foram acrescentadas as doze biografias dos doutores honoris causa escolhidos pela Congregação ${ }^{99}$, encerrando o panteão dos 
ilustres, quase todos merecedores de retratos fotográficos anexados a seus respectivos textos.

Os capítulos seguintes do livro distanciavam-se do critério biográfico e focalizavam aspectos institucionais: uma breve história da Escola de Enfermagem, criada em I938; dos cursos de graduação de Ciências Biológicas (I 966), de Fonoaudiologia (I968), de Ortóptica (I962); e dos cursos de pós-graduação, contendo uma relação de teses de mestrado e doutorado, realizadas entre I97 I e I976. Em seguida, apresentavam-se brevemente o CAPB, a Associação dos Ex-Alunos, a Biblioteca Regional de Medicina (Bireme) e os "Benfeitores e colaboradores" ${ }^{\text {Ioo. }}$ Também nessa parte, o autor cedeu espaço àqueles que deram suporte ao setor administrativo ${ }^{\text {Ior }}$. O capítulo sobre a "Evolução das Cátedras da Escola Paulista de Medicina" e as listas das teses defendidas perante a EPM encerraram a descrição institucional ${ }^{102}$.

Por fim, no capítulo "Discursos e Lembranças", o autor publicou suas próprias saudaçóes a calouros e novos colegas, bem como um necrológio e o discurso comemorativo que proferiu aos quarenta anos da Escola. Finalizando as quase quatrocentas páginas da obra, lemos as "Perspectivas para o Futuro" - proposta sucinta em doze itens que estabeleciam diretrizes para fortalecer a EPM enquanto formadora de médicos e pesquisadores ${ }^{103}$. Embora datem de 1953 , não pareciam, no entender do autor, ter perdido a relevância. Valle reconhece que o Brasil estava na "retaguarda das naçóes modernas" e que não deveria mais continuar como simples repetidor de conhecimentos alheios e usufrutuário das "conquistas de outros povos". Apelava, assim, à responsabilidade do governo em proteger "os homens da ciência, os professores que lutam por viver em seus laboratórios, nas suas bibliotecas, junto de seus alunos, compartilhando de seus progressos" ${ }^{\text {104. }}$

A reflexão de Valle avança quanto às preocupaçóes da EPM de manter-se fiel aos seus objetivos, aprovados pela Congregação: "Constituirse em centro de excelência para, em alto nível, desenvolver atividades de ensino, pesquisa e prestação de serviços na área das ciências biológicas, do comportamento e da saúde”. Valle expressa apreensão acerca do destino que espera a Escola. Para assegurar esses objetivos, indaga se a instituição permaneceria escola superior isolada vinculada ao Ministério da Educação e Cultura ou se ela seria transformada numa universidade especializada em ciências da saúde. O livro encerra-se tocando na questão da crise do ensino superior, decorrente do "elevado número de alunos, da reduzida classe de professores e da deficiência do ensino objetivo, prático e não livresco". Instituiçôes como a Coordenação de Aperfeiçoamento do Pessoal de Nível Superior (Capes) e a Fundação
Macedo Cardoso (p. 6I); Eduardo Ribeiro Costa (p. 65); Fausto Guerner (p. 68); Felício Cintra do Prado (p. 7I); Felipe Figliolini (p. 76); Flávio Oliveira Ribeiro da Fonseca (p. 82); Henrique da Rocha Lima (p. 86); Jairo de Almeida Ramos (p. 92); João Moreira da Rocha (p. 96); José Bonifácio Medina (p. 99); José Ignácio Lobo (p. I04); José Maria de Freitas (p. Io8); Luiz Cintra do Prado (p. I 2); Marcos Lindenberg (p. II6); Nicolau Maria Rossetti (p. I2 I); Octávio de Carvalho (p. I25); Olivério Mário de Oliveira Pinto (p. I30); Otto Guilherme Bier (p. 134); Paulo Mangabeira Albernaz (p. I38); Pedro Marcondes de Alcântara Machado (p. I42); Rodolfo de Freitas (p. I47). José Ribeiro do Valle, op. cit.

98. Abrahão Rotberg, André Dreyfus, Azarias de Andrade Carvalho, Darcy de Mendonça Uchoa, Edgard de Melo Mattos Barrozo do Amaral, José Barbosa Corrêa, José Leal Prado de Carvalho, José Ribeiro do Valle, Juvenal Ricardo Meyer, Lauro Monteiro da Cruz, Luiz Pereira Barretto Neto, Moacyr Eik Álvaro, Moacyr de Freitas Amorim, Nelson Gioia Planet, Nylceo Marques de Castro, Paulino Watt Longo, Paulo Enéas Galvấo, Renato Locchi, Renato de Toledo, Thales Cesar de Pádua Martins, Walter Büngeler, Walter Sidney Pereira Leser. Idem, pp. 153-232.

99. Raul Leitão da Cunha, Clemente Miguel da Cunha Ferreira, Frank Norman Wilson, Ignácio Chavez, Eurico Gaspar Dutra, Horácio Lafer, Clemente Mariani Bittencourt, Daniel Bartholomew Kirby, Clóvis Salgado da Gama, Alexandre Marcondes Filho, Robert Briggs Watson, Amador Neghme Rodriguez. Idem, pp. 237-264.

Ioo. Idem, pp. 289-300. Nesse último item, lê-se uma biografia sucinta de Maria Thereza Nogueira de Azevedo, cuja ajuda teria sido imprescindível para a construção do Hsp. O pavilhão que levou seu nome fora inaugurado em Is de junho de 1937. Depois, abrigou outras funçóes, tendo sediado o САРB e, posteriormente, foi demolido para dar lugar a um novo edifício. O autor lamenta que, com a demoliçáo, teria desaparecido o nome desta "benfeitora" mas 
nấo a dívida de honra que com ela contraiu a EPM.

IOI. São citados o primeiro secretário Francisco de Assis e Almeida, o contador Nicolau Duarte Barbosa, o almoxarife Alfredo Fragoroso Pereira, Oswaldo Biffoni Pellegrino e Ida Vittoria Paulini.

I02. José Ribeiro do Valle, op. cit., pp. 3OI-344.

I03. Idem, pp. 37 I-373.

I04. Idem, p. 373.

I05. Idem, pp. 374-377.

Io6. Idem, pp. 23 e iा9, respectivamente.

I07. Segundo as biografias, entre os 33 fundadores, onze atuaram no Movimento. Com exceçấo de Eduardo Ribeiro da Costa, que era engenheiro químico e prestou serviço na Comissão Técnica Civil de Material Bélico, os demais auxiliaram como médicos. A esse respeito, ver capítulo II.

I08. "Foram personalidades marcantes e solícitas que tudo deram de si na consolidaçấo da EPM", conclui o autor (José Ribeiro do Valle, op. cit., p. 298). Aposentada na época, Paulini teria vivido "os tempos difíceis da Escola particular, carente de recursos mas rica em entusiasmo e dinamismo. Homenageada por várias turmas de doutorandos, é um repositório de recordaçooses de mestres e alunos, de tudo aquilo que compóe a história humana da instituição". Idem, p. 300. de Amparo à Pesquisa no Estado de São Paulo (Fapesp), bem como o esforço do Governo Federal em organizar centros de excelência e de pós-graduação, apontavam para aperfeiçoamentos e avanços. Valle pleiteava uma nova independência do Brasil, que conseguisse resolver os seus problemas por "nós mesmos" - o que requeria uma "ciência bem conduzida e bem aproveitada" ${ }^{\text {105. }}$

Pelo tipo de abordagem implícito ao conceito de poliantéia, não surpreende que as biografias fossem escritas em um tom laudatório, focadas no sucesso profissional desses homens. Além disso, foram redigidas por colaboradores da área médica, muitas vezes da própria EPM. Dos 48 colaboradores incumbidos de escrever as biografias, 39 (incluído o próprio Valle) eram ou estavam de alguma forma ligados à EPM. Quando havia uma atuação voltada às artes, letras ou música, transpondo o campo profissional médico, isso era mencionado como mais um fator de enriquecimento biográfico. Lemos Torres e Lindenberg eram casos exemplares, para os quais os biógrafos não pouparam elogios. Torres teria chegado a "resultados plásticos de invejável requinte" e Lindenberg foi o escultor do "primoroso" busto de Carvalho, além da efígie de Lemos Torres ${ }^{\mathrm{I} 06}$.

Chama atenção a referência, na biografia dos fundadores, à participação ou adesão deles ao Movimento de $1932^{107}$, questão que até então não surgira explicitamente nas memórias e histórias da EPM. Como observamos anteriormente, o que havia era uma relação, enfatizada com freqüência, entre a fundação da EPM e a derrota dos paulistas em I 932 - derrota que náo teria furtado o orgulho dos mesmos - motivando, aliás, o próprio projeto de erguer uma escola médica e um hospital-escola. O Manifesto de Fundação é uma das referências mais recorrentes com o objetivo de reiterar essa associação entre o significado histórico de 1932 e a vocação institucional da Escola.

Não pretendo desvelar aqui todos os aspectos que dão contornos às biografias, tanto dos fundadores como dos demais personagens descritos, e menos ainda pôr em questão o quanto eles colaboraram para o desenvolvimento da EPM. Mas não se pode deixar de atentar para algumas omissóes flagrantes. A grande maioria dos funcionários administrativos não encontra lugar nas biografias. A posição deles na hierarquia institucional não dava acesso ao panteáo dos ilustres, embora a instituição não funcionasse sem secretárias, técnicos de um modo geral, pessoal de limpeza ou de manutenção. No item "Benfeitores e colaboradores", o autor abre um breve espaço aos secretários, inspetores de educação, almoxarifes e secretárias, em especial a secretária Ida Paulini ${ }^{108}$. Apesar de reconhecer o quanto essa personagem teria 
a revelar, ela não figurava como contribuinte da história. Seu lugar se limitava à colaboração digna de homenagens, mas não necessariamente ouvida como voz autorizada a narrar alguma história. Essa breve menção definia as fronteiras entre o campo dos participantes ativos e o dos coadjuvantes na narrativa do processo histórico da instituição, corroborando para uma construção elitista da própria história.

Outro silêncio revelador é o que recaiu sobre as circunstâncias em que o livro foi escrito: a crise desencadeada pelo golpe militar de I964 e a fase ulterior de perseguição e cassação, por meio da instalação dos IPMs na Escola. Voltemos ao caso de Lindenberg: em sua biografia, enaltecia-se seu interesse pelo conhecimento humanista, pelas artes e pela música, além do brilhantismo científico de suas realizaçôes na EPM quando dela diretor, mas omitiu-se sua cassação. A breve existência da UFSP, onde ele deveria ocupar o cargo de reitor (o que o texto náo menciona) é considerada como "empreendimento que vinha ao encontro de uma legítima aspiração da EPM, qual seja a de integrar uma organização universitária [...]”. Esse processo fora interrompido pelos "acontecimentos políticos de I964", descritos pelo eufemismo de processo "prenhe de incompreensóes e radicalismos" ${ }^{\circ}$.

Enquanto a narrativa histórica de Valle era reticente face aos acontecimentos que envolveram a ditadura e a cassação de Lindenberg, ela revela por outro lado a participação de Rodolfo de Freitas na "revolução de I964". Seu biógrafo afirma que, na sala ocupada por ele no HsP, havia "reunióes permanentes com alguns homens públicos que lá iam ter todas as manhãs". Em uma delas, "Madre Ana de Lourdes [...] - da equipe do hospital, foi, então a proponente da famosa Marcha da Família com Deus pela Liberdade" "

Se em Albernaz o trabalho institucional retido em atas tornou-se fonte cabal para elaborar uma história "verdadeira" da EPM, em Valle (Figura 9) a história era reescrita a partir de outros opúsculos e de outras fontes não explicitadas, que homenageavam personagens, em sua maioria masculinas, atuantes em maior ou menor grau na construção da Escola. Ao leitor não se esclarece de que forma coletaram-se as informaçôes sobre os biografados e quais os critérios empregados.

Outro ponto a ser ressaltado é a iconografia. Quase como frontispício, uma fotografia aérea do conjunto da EPM em Vila Clementino (sem data), e na seqüência a reprodução de uma fotografia colorida (única) do mural de Pietro Nerici, que se encontra no saguão do Departamento de Bioquímica e Farmacologia, no Edifício Leal Prado ${ }^{\text {II }}$. O leitor, no entanto, não obtém informaçôes sobre o afresco. Somente uma data em parênteses indica o ano de sua execução: I 956. O restante
I09. Silvio J. Pinto Borges, "Marcos Lindenberg”, em José Ribeiro do Valle, op. cit., p. II8.

I Io. Afiz Sadi, "Rodolpho de Freitas", em José Ribeiro do Valle, op. cit., p. I48. Cunhado de Octávio de Carvalho, Rodolfo de Freitas foi professor catedrático de urologia na EPM. O assunto será tratado com mais detalhes no capítulo III.

III. Sobre o afresco, ver a reprodução do texto publicado n'O Biceps 23 (27), set. I962, pp. 40-4I, onde também pode-se observar a obra e encontrar explicaçóes para seus detalhes. Sobre o pintor Pietro Nerici, sabe-se que, além desta obra, ele foi participante do Saláo Paulista de Belas Artes (entre 1948 e 1963, com um longo intervalo na década de I950) e da Bienal de São Paulo (em I963 e 1965), cf. Enciclopédia de Artes Visuais. 


\section{A escola Paulista de medicina}

DADOS COMEMORATIVOS DE SEU 40.0 ANIVERSÁRIO (1933-1973) E ANOTAÇס̃ES RECENTES

Figura 9. Capa do livro A Escola Paulista de Medicina: Dados Comemorativos de seu 40 Aniversário (1933-1973) e Anotaçóes Recentes, de autoria de José Ribeiro do Valle, publicado em 1977.

das imagens é, em sua maioria, composto por retratos das personagens biografadas. A elas ainda se acrescenta uma outra parte, bem menor, de fotografias de grupo e algumas imagens de edificaçôes.

Nessa abordagem histórica emergem algumas características marcantes. Novamente a publicação do Manifesto de Fundação, na introdução da obra, pode ser lida como uma memória cujo conteúdo serve de referência ao presente. A menção à bravura dos paulistas é reiterada; a dedicação ao povo de São Paulo, necessitado de assistência médico-hospitalar continua em debate; as carências no ensino médico prevalecem; a dedicação filantrópica dos fundadores se trans- 
figura em empenho e dedicação acima de qualquer interesse pessoal. Nesse sentido, as biografias são construídas apontando a coerência do projeto institucional respaldado nas intenções do Manifesto, cujo sucesso é tributário da vocação, do trabalho e da dedicação destes homens. A instituição é tratada isoladamente, e seu caminho é traçado como a marcha de um herói solitário, desafiando o tempo e as vicissitudes que a trajetória impóe, construindo a sua própria história. $\mathrm{Na}$ narrativa histórica, a instituição jamais aparece em relação a outras escolas médicas e hospitais-escola. Ao descrever o incrível desenvolvimento da EPM, que nasceu do nada e tanto ergueu e conquistou, dá-se especial enfoque aos fundadores e colaboradores, sublinhando a suas exímias qualificações e omitindo-se a existência de um quadro de funcionários e alunos que cumpriram um papel relevante no processo. Por fim, não é demais repetir que também esse livro é uma obra historiográfica escrita por punhos endógenos, com o claro objetivo de celebrar a instituição. Isso não descarta a reflexão de Valle acerca das dificuldades coevas da instituição. No entanto, por mais crítico que ele afirme ser, sua visão foi condicionada pelo objetivo da obra, bem como pela relação visceral que ele cultivava com a própria instituição e seus membros.

\section{O Jubileu de Ouro}

Finalmente, jubileu de ouro. Cinqüenta anos de EPM. A comissão para organizar essa efeméride foi maior que a dos quarenta anos. Encabeçada por uma comissão coordenadora, as comissóes social, cultural, de finanças, esportiva e de divulgação ainda se subdividiam em diversas subcomissóes.

Como de praxe, a instituição não somente se autocelebra com as atividades já consagradas na tradição (culto ecumênico, sessóes solenes, inaugurações, simpósio científico, competiçôes esportivas), mas também com selos e logotipos. O carimbo postal comemorativo foi lançado em sessão solene da Congregação, em Io de junho de I983, na presença do governador do Estado, André Franco Montoro ${ }^{112}$.

Em destaque, a inauguração do Instituto Nacional de Farmacologia $^{113}$, com a presença da ministra da Educação, Esther de Figueiredo Ferraz, "uma das mais importantes atividades comemorativas do $50^{\circ}$ aniversário da Escola Paulista de Medicina” ${ }^{\text {I } 4}$.

Nessa celebração, a menção ao Manifesto de Fundação da EPM, editado havia exatos cinqüenta anos, realizou-se junto às homenagens feitas aos professores que o assinaram. Leu-se o nome dos signatários já
II2. Estavam presentes ainda Dalva Souto Maior (delegada regional do MEC em São Paulo, representando a ministra Esther de Figueiredo Ferraz), João Yunes (secretário de Estado da Saúde), José da Silva Guedes (secretário de Higiene e Saúde do Município), professores, estudantes, ex-alunos e funcionários. No programa da abertura solene, consta uma lista de quem discursaria. Havia representantes da Congregação (Magid Iunes, diretor da EPM), dos professores fundadores (Pacheco e Silva), dos ex-alunos (Silvio dos Santos Carvalhal), da Associação dos Docentes (Valéria Petri), dos alunos (o acadêmico César Suguimoto) e dos funcionários (Jorge Yamane). "Paulista de Medicina, 50 anos", Folha de S. Paulo, 2 jun. 1983 .

II3. Segundo Ribeiro do Valle, o Instituto destinava-se ao ensino de pósgraduação e às atividades de pesquisa científica nas áreas de farmacologia, bioquímica e biofísica.

II4. "Os Cinqüenta Anos da Escola Paulista de Medicina", Jornal da Tarde, 3 out. I983, p. I3. 


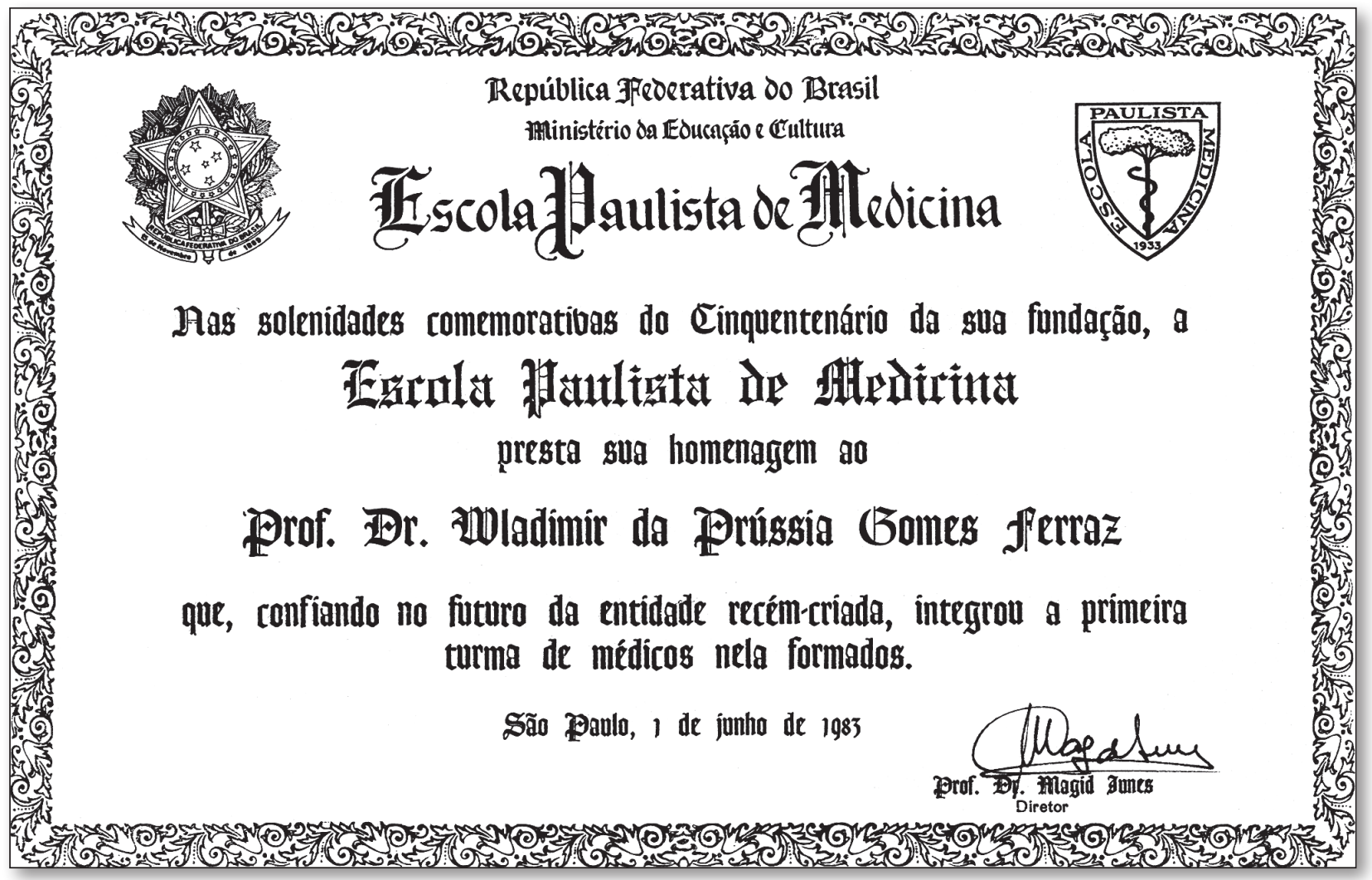

II5. "Sessão Solene da Congregação - Cinqüentenário da Escola Paulista de Medicina”, I jun. 1983, Acervo do ceHFi, pasta ํo 6 - Aniversário: Jubileu de Ouro da EPM 5.
Figura io. Pergaminho em homenagem aos fundadores, de Io de junho de 1983. Fonte: Acervo do cenFi, pasta no 17 - Aniversário: Jubileu de Ouro da EPM II.

falecidos e fez-se um minuto de silêncio. Em seguida, entregaram-se os pergaminhos aos fundadores ainda presentes (Figura Io).

Segue-se a galeria dos homenageados: alunos da primeira turma, funcionários - representados pelo mais antigo em atividade - e instituiçôes que apoiaram o desenvolvimento da Escola ${ }^{115}$. As palavras do diretor Magid Iunes, em nome da Congregação, fizeram menção ao passado da EPM, em especial ao momento da fundação. Ao referir-se às condiçóes presentes, a questáo da universidade reapareceu. Computando a diversidade dos cursos - graduação em medicina, ciências biomédicas, ortóptica, fonoaudiologia, além da pós-graduação - Iunes sugeriu que a Escola fosse vista, "na realidade", como uma "Universidade de Ciências da Saúde". Na breve retomada da história institucional, a federalização era compreendida como um ato de reconhecimento do alto nível de ensino da Escola pela Uniáo, de tal forma que ela fora entáo incluída na rede oficial de ensino superior. Mas também o Estado e o município teriam prestado farta ajuda à instituição, bem como outros 
órgãos nacionais (CEF, Finep, CNPq, Capes, Fapesp) e internacionais (fundações como a Rockefeller, W. K. Kellogg, Ford, Inter-Americana, além da opas). Em seu discurso, era apresentada uma instituição que, apesar das dificuldades, seguiu sua trilha sem maiores obstáculos, sem se desviar de seu caminho ascensional. As palavras de encerramento são sinais evidentes disso:

Meio século se passou. Com pertinácia e profícuo labor, vencendo desafios à primeira vista insuperáveis, nosso corpo docente conseguiu acompanhar extraordinários avanços que nesse período ocorreram no campo das ciências da saúde, assegurando aos estudantes uma formação profissional, incontestavelmente de elevado padrão ${ }^{116}$.

A EPM formou profissionais destacados em docência e pesquisa, não somente seguindo carreira na própria Escola, mas pelo país afora, levando "o saber e os exemplos colhidos na Alma Mater" ${ }^{117}$. A solenidade foi encerrada com as palavras do governador, reiterando a imagem da EPM como modelo de ensino: "uma obra que se tornou exemplo de cultura e ação social, digno de ser seguido por toda a nação brasileira" ${ }^{\text {I18. }}$.

Encontramos mais louros em pequena publicação datada de Io de junho de 1983, intitulada Cinqüentenário da EPM - Reminiscência, Recordação, Saudade, Gratidão, de autoria do ex-aluno Archimedes Lammoglia. Em rimas, o autor fez um retrospecto da EPM, evocando o nome dos fundadores. Ao iniciar o percurso, aproxima a coincidência numérica dos 33 fundadores em 1933 com os 33 anos de idade do Cristo martirizado, estabelecendo uma associação explícita entre o empenho dos fundadores e a obra divina de Cristo - voltada ao sacrifício, à redenção da humanidade, à caridade e ao amor. Nesse contexto, a questão paulista dava contornos ao empreendimento:

[...] Entusiastas, desprendidos idealistas,

Lançaram-se quais desbravadores

Como as gloriosas Bandeiras Paulistas

Para darem a São Paulo e à Nação

Uma Escola para formar Doutores

De solidariedade e amor cristão.

Uma plêiade de abnegados

Trinta e três, idade de Cristo

Intrépidos, decididos, arrojados $[\ldots]^{119}$.

\footnotetext{
II6. Discurso de Magid Iunes, $\mathrm{I}^{\mathrm{o}}$ jun. 1983, Acervo do сенғi, pasta no 6 Aniversário: Jubileu de Ouro da EPM 5 , pp. 4-5.

I 7 . Idem, ibidem.

I18. "Paulista de Medicina, 50 Anos", Folha de S. Paulo, 2 jun. 1983.
}

II9. José Francisco Archimedes Lammoglia, Cinqüentenário da EPM: Reminiscência, Recordação, Saudade, Gratidão. São Paulo, brochura, Io jun. 1983 , Acervo do ceHFi, pasta no 17-Aniversário: Jubileu de Ouro da EPM II, p. 20. 


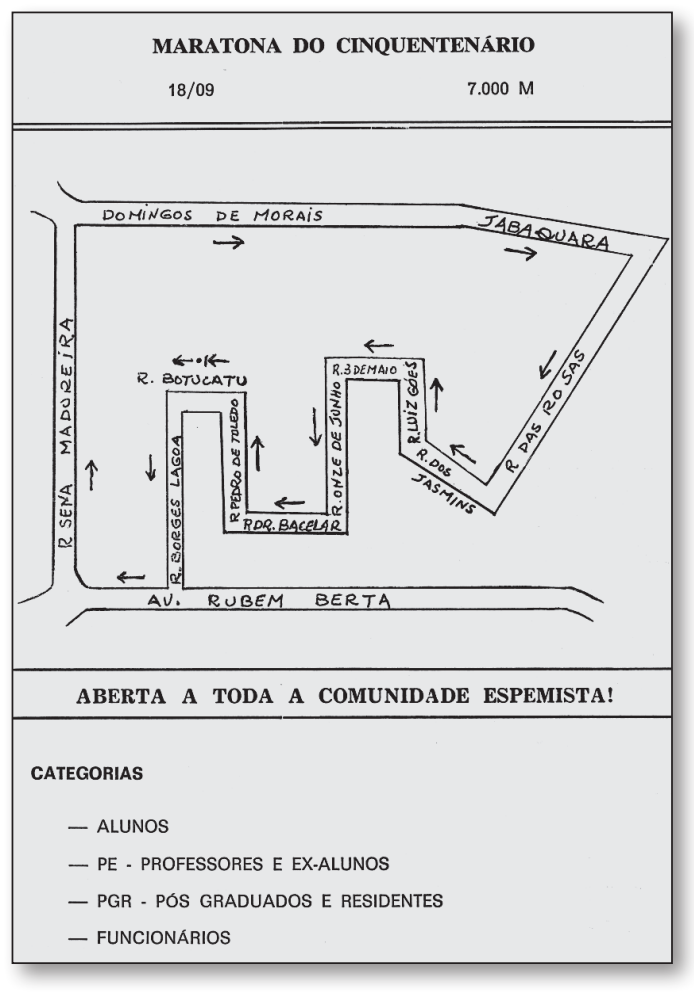

Figura i I. Circuito da maratona [sic] do cinqüentenário pela Vila Clementino. Fonte: Programa das comemoraçóes esportivas do cinqüentenário da EPM, I 983 - Acervo do CeHFi, pasta nํ I 9 - Associação dos Ex-Alunos da EPM e Associação dos Assistentes da EPM.

A cada um dos signatários do Manifesto de Fundação, Lammoglia dispensou dois versos de elogios rasgados, incluindo nesse rol os primeiros funcionários que auxiliaram técnica ou administrativamente a Escola. Se no início comparou a obra dos fundadores com as bandeiras paulistas, ao final do poema a "paulistidade" agregada ao movimento de 1932 emprestava sentido e justificava a dedicação à obra epemista:

Quase todos constitucionalistas de 32,

Que sonhavam com liberdade

Encontraram derivação um ano depois

Num gesto humano paulista, de austeridade

Continuaram o povo servindo

Com a Escola viril altaneira.

Que cada vez mais, vem-se constituindo

Em orgulho da Pátria brasileira ${ }^{\mathrm{I} 20}$. 
Os cinqüenta anos também inspiraram a composição de um hino em homenagem à Escola, composto por Yaro Ribeiro Gandra (letra e música) - formado na EPM em I945 e, na ocasião, um renomado professor da Faculdade de Higiene e Saúde Pública da UsP, especializado em nutrição ${ }^{\text {I2I }}$ - e com arranjo musical do conhecido músico Mário Albanese ${ }^{\mathrm{I} 22}$. Em sua simplicidade, a letra retoma os referenciais já tão sedimentados na memória epemista: “[...] Escola Paulista / em tua história muitas glórias, homens de valor / em São Paulo trajetória edificante / és o orgulho desta terra bandeirante / [...]". E salienta a sua vocação acadêmica e assistencialista: "No afã de nossas vidas / não esquecemos de cumprir nosso dever, / tanto ao rico como ao pobre acudimos / com carinho e a perícia do saber. / O ensino e a pesquisa / praticamos com devoção [...]" I23 (Figura I I).

\section{Os Sessenta Anos e Lançamento de Obra Comemorativa}

Em I993, a EPM completava sessenta anos. As dimensóes dos festejos cresceram conforme aumentara a idade e a importância da instituição no cenário local e nacional. As festividades vinham sendo anunciadas desde meados do ano anterior no Jornal da Paulista. Além das matérias que contam a história da EPM, bem como a trajetória de alguns ex-alunos e as entrevistas com algumas personalidades, mensalmente publicou-se o trabalho de cada uma das comissões (social, divulgação, finanças, esportiva) e abriu-se o concurso de criação de um símbolo comemorativo aos sessenta anos da EPM. Igualmente aproveitou-se a efeméride para traçar um perfil contemporâneo da instituição, sublinhando sua alta produtividade acadêmica, seu quadro de professores qualificados ("a mais alta titularidade do país”), a projeção de sua pós-graduação e o número de cursos ${ }^{124}$.

As comemoraçóes iniciaram-se igualmente no histórico Io de junho, dia em que o Manifesto de Fundação veio a público em I 933. Dessa vez, a sessão solene de abertura foi realizada no Teatro Marcos Lindenberg $^{\text {I25 }}$ e não na Assembléia Legislativa, como ocorrera havia dez anos. Antes da sessão, um culto ecumênico com a participação de um rabino, de um padre e de um pastor. $\mathrm{O}$ primeiro dia das comemoraçôes encerrou-se com um recital de piano.

Como nas comemoraçóes anteriores, a programação incluiu atividades sociais, culturais, esportivas e científicas ao longo de dezoito dias. No segundo dia, como um diferencial dessa comemoração, exibiu-se um vídeo sobre a história da EPM e, em seguida, foram lançados o livro celebrativo $^{\mathrm{I} 26}$ (Figura I 2) e um número especial da Revista do Hospital São Paulo sobre os sessenta anos de pesquisa na $\mathrm{EPM}^{\mathrm{I27}}$.
I2I. Para uma densa nota biográfica, ver José Eduardo Dutra de Oliveira, "Pioneiros das Ciências Nutricionais no Brasil”, em Héctor Bourges Rodríguez et al. (coords.), Historias de la Nutrición em América Latina.

I22. Instrumentista (pianista), compositor, professor de música, radialista, advogado, jornalista, produtor $\mathrm{e}$ apresentador de programas de televisão, Albanese iniciou seu aprendizado musical com a mãe, ingressando, em seguida, no Conservatório Dramático e Musical de São Paulo. Mais tarde, estudou com Antonieta Rudge, Hans Joachim Koellreutter, Samuel Arcanjo, João Caldeira Filho, Mário de Andrade e Rossini Tavares de Lima. Foi o criador em 1964 do neologismo "jequibau" para definir o ritmo $5 / 4 \mathrm{da}$ música brasileira. Ver http://www.dicionariompb.com.br/verbete.asp?tabela $=\mathrm{T}$ FORM_A\&nome=Mario+Albanese, acesso em jan. 2008.

I23. Yaro Ribeiro Gandra (letra e música) e Mário Albanese (arranjo), Acervo do CeHFi, pasta no ${ }^{2}$ - Hinos e Gritos de Guerra da EPM.

I24. "A Excelência dos Cursos da EPM nos 60 Anos”, Jornal da Paulista, 6 (62), 9 fev. 1993 .

I25. O auditório fica no Edifício de Anfiteatros, $2^{\circ}$ andar, e comporta 387 pessoas. Foi inaugurado em outubro de I990, na gestão de Nader Wafae.

126. Escola Paulista de Medicina: 60 Anos de História.

127. Revista do Hospital Säo Paulo, 5 (nº especial), 1993. 
I28. A comissão foi formada por Octavio Ribeiro Ratto (professor titular de clínica médica da Escola Paulista de Medicina, membro do conselho do Departamento de Medicina em I965 e chefe da Disciplina de Pneumologia em I966, cf. http://www.unifesp.br/dmed/transicao. htm, acesso em dez. 2007; Luiza Kimiko Matsumura (professora do Departamento de Medicina, Disciplina de Endocrinologia Clínica), e Hanna Augusta Rothschild (química, que se aposentou da Unifesp em 2005, cf. http://www. unifesp.br/pradmin/drh/Grupo\%2o ApH.htm, acesso em dez. 2007.

I29. Além disso, mencionavam-se as realizações institucionais: o Pavilhão Maria Thereza de Azevedo, o berço do HsP, a Escola de Enfermagem, a modernização do vestibular, a transformação da cadeira de Higiene na de Medicina Preventiva, a introdução do sistema departamental, a criação do curso de Ciências Biológicas, sediar a Bireme (Biblioteca Regional de Medicina), o curso de pós-graduação em nível de mestrado e doutorado. Escola Paulista de Medicina: 60 Anos de História, p. 2.

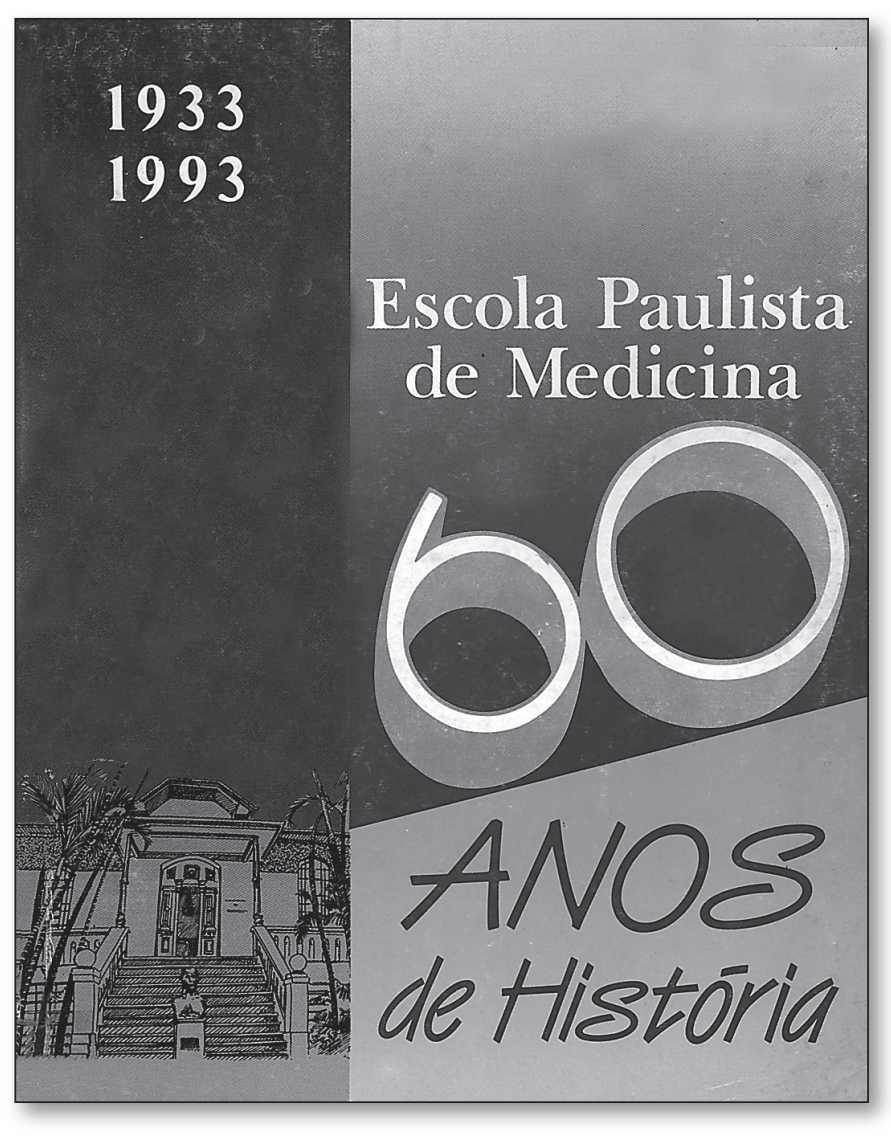

Figura i 2. Capa do livro Escola Paulista de Medicina: 60 Anos de História, publicado em I 993 .

Pela primeira vez na história da instituição, lança-se um livro comemorativo junto com os festejos. Sua autoria, porém, não escapa dos círculos já conhecidos da EPM, sendo fruto do trabalho de uma comissão interna da instituiçẫo ${ }^{\mathrm{I} 28}$. No prefácio, ao contrário do livro de Albernaz, explicitou-se o procedimento do trabalho para elaborar a história e o livro como um todo, que parte de uma indagaçáo pouco surpreendente: "como a Entidade (EPM) conseguiu tamanho progresso?”. Tratava-se de uma óbvia referência ao fenômeno tanta vezes mencionado e que caracterizava a instituição: ter começado tăo precariamente e chegar ao colosso que era entáo. A pronta resposta induzia o leitor a sanar qualquer dúvida: a presença contínua do pioneirismo e do espírito criativo ${ }^{\mathrm{I} 29}$.

A preocupaçáo com o método de trabalho é igualmente revelada no prefácio. O objetivo era reter o máximo de informaçóes e, para tanto, foram consultados os livros de atas dos colegiados da EPM e as 
publicaçôes sobre a sua história. Procurou-se contatar pessoas que tiveram farta vivência na instituição, enviando-lhes questionários cujas respostas contribuíram para a elaboração da história da instituição, uma história que "precisa ser escrita, reescrita, atualizada e mesmo reformulada, já que existe um passado, um presente e um porvir" ${ }^{\text {130. }}$

A curta introdução, assinada pelo então diretor da EPM, Manuel Lopes dos Santos, reforçava a idéia de o livro não ter autoria definida e nem veleidades literárias, mas somente conter "verdades", "sentimen-

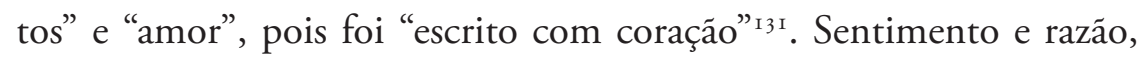
impressões subjetivas e verdades objetivas não se excluem nessa proposta de contar a história dos sessenta anos da instituição.

A forma do livro mostra a priorização da estrutura institucional. O capítulo primeiro narra os "60 anos de história” da EPM. Os seus capítulos restantes foram dedicados aos departamentos, aos cursos, ao HSP, aos centros de apoio (Biotério, Bireme, Centro de Apoio à Pesquisa e ao Ensino, Centro de Informática em Saúde, Microscopia Eletrônica) e às associaçóes (Associação dos Docentes da EPM, Associação dos Ex-Alunos da EPM, Associação dos Funcionários da EPM, CAPB). O capítulo sobre os departamentos é o mais longo, ocupando cerca de dois terços do livro. Cada departamento é contemplado em sua história, produtividade, linhas de pesquisa, corpo docente e especificidades. O livro objetivava não somente contar a "verdade" com o "coração", conforme anunciado no prefácio, mas igualmente queria abarcar a totalidade, colocando-a numa perspectiva evolutiva. Em cada um dos tópicos tratados, há um esforço de recuar no tempo e explicar ao leitor as transformaçóes e os avanços.

O capítulo apresenta um abrangente panorama de como a instituição foi crescendo e se desdobrando até chegar às vésperas de se tornar uma "Universidade da Saúde". Não repetirei o que o texto já faz de maneira clara. Para o meu propósito, apresentarei com mais detalhes alguns aspectos desta história.

Também aqui, as referências ao período da fundação demarcavam o "espírito" da EPM. Foram escolhidos trechos do Manifesto que se reportam ao descontentamento em virtude da derrota na Revolução Constitucionalista, bem como aos alunos aprovados no vestibular da Faculdade Medicina que não obtiveram vaga, ensejando a elaboração do projeto de uma nova escola médica. É como se "a vitalidade espiritual de São Paulo”, expressada no Manifesto, encontrasse sua materialização na obra da EPM que, nas palavras de Octávio de Carvalho, nasceu "modesta na parcimônia justa de seus instrumentários, porém soberba na majestade de seu idealismo desinteressado". A fase da fundação, ou
I30. Idem, p. 3.

I3I. Manuel Lopes dos Santos, "À Guisa de Introduçáa”, Escola Paulista de Medicina: 60 Anos de História, p. 4. 
132. Escola Paulista de Medicina: 6o Anos de História, pp. 6-I2.

133. Idem, p. I6.

I34. Lindenberg morreu em final de 1989, idem, p. 26. seja, os anos de I933 a I938 - quando do reconhecimento da EPM pelo Governo Federal e a formatura da primeira turma -, ocupam quase um terço do capítulo ${ }^{132}$.

A história da instituição segue, então, um eixo cronológico balizado pelas sucessivas gestóes das diretorias. Os momentos cruciais da vida institucional, como a federalização, são descritos como dificuldades circunstanciais. Uma delas era a composição do corpo docente. Quando a EPM foi federalizada, em janeiro de I956, os assistentes que ainda estavam na ativa foram indicados para a nomeação, em detrimento daqueles que para ela também trabalhavam, em grande parte, voluntariamente, mas estavam afastados por razóes econômicas. $\mathrm{O}$ problema foi resolvido por meio de uma ação judicial contra a EPM, impetrada pelos que se consideraram prejudicados. Vitoriosos, foram igualmente nomeados, gerando um desequilíbrio no quadro de docentes. Em algumas cátedras havia excesso de professores; em outras, falta. Segundo os autores, esses problemas teriam sido resolvidos com o decorrer do tempo, graças a um planejamento mais elaborado do corpo docente, à paulatina transformação das cátedras em departamentos e a criação do Estatuto do Magistério Superior Federal ${ }^{133}$.

Outro momento atribulado da instituiçáo foi tratado no livro, pela primeira vez, com um pouco mais de detalhes, embora não avance muito na elucidação dos acontecimentos. Trata-se do episódio da incorporação da EPM na UFSP e da cassação de Marcos Lindenberg. A exoneração de Lindenberg do cargo de diretor da EPM, que o deveria ocupar por três anos, se explica pelo fato de ter sido designado presidente do Conselho Consultivo e Deliberativo da UFSP e, igualmente, para responder pela reitoria da recém-criada Universidade. Os fatos são arrolados conforme decisóes tomadas na Congregação ou pelo Governo Federal. O golpe militar é denominado "Movimento de 3 I de março". Em setembro daquele ano, o presidente da República empossou o novo diretor da EPM, José Maria de Freitas, indicado pela Congregação em lista tríplice. No mês seguinte, a EPM era desligada da UFSP pela lei federal no 4.42 I, de 6 de outubro de I964. Não há explicaçôes ou interpretaçóes a esse respeito. Em seguida, menciona-se a instalação do primeiro e do segundo IPM na Escola. O primeiro teria sido "extremamente rígido e, seguramente, iria afetar muitos docentes e componentes do quadro administrativo. As suas conclusóes foram rejeitadas”, informam os autores. O segundo teria sido mais tolerante, e seus inquiridores "entenderam a posição e o pensamento de muitos docentes e administradores, mas infelizmente determinaram a cassação de alguns professores [...]”. Entre eles, o único citado é o Lindenberg, àquela altura já falecido ${ }^{134}$. 
Ao leitor não se esclarece como e porque esses inquéritos foram instalados e, sobretudo, quem deles participou ${ }^{135}$. Denotada como "fase de castigo", a ditadura foi um mal, porém "não muito duradouro". Segundo os autores, os "cassados voltaram através da anistia”. O caso de Lindenberg, que "amargou tragicamente o seu fim de vida", explica-se por razóes familiares ${ }^{136}$.

A crise que assolou a instituição em I 970 também foi abordada. A gestão de Horácio Kneese de Mello passava pelas dificuldades advindas de uma greve estudantil - refletindo, segundo os autores, o "clima de greves, movimentos de massa e incertezas" que dominava o Brasil daquele momento. Ressaltou-se a habilidade do diretor, que pediu demissão por achar que não teria condições de gerenciar os desafios, mas cujo pedido foi recusado pela comunidade epemista. Mello seguiu em seu cargo e conseguiu superar as dificuldades. Mais detalhes não foram apresentados ${ }^{137}$.

Os autores lembram que as discussóes para integrar a EPM a uma universidade foram retomadas em I979, em resposta a um ofício-circular do secretário de Ensino Superior do MEC, Guilherme Marcos la Penha. Transcrevem, resumidamente, o que se vislumbrava com a transformação em universidade. As metas seriam gerar conhecimento proveitoso para a sociedade e revê-lo continuamente; realizar pesquisas e atuar no ensino sempre em interação com a comunidade. Os exemplos que ajudariam a definir o perfil dessa universidade, que não deveria desdobrar-se em dimensôes incontroláveis, seria a área de ciências do Massachussets Institute of Technologie, a área de física e matemática da Princeton University e a área de ciências da saúde do Rockefeller Institute. No entanto, no arrolamento cronológico dos fatos, um assunto é simplesmente substituído pelo seguinte, e o leitor não compreende o que impediu a continuação das discussôes.

Somente em I986, ao tratar da gestão de Magid Iunes, o assunto voltava à cena, abordando-se um anteprojeto para transformar a EPM em uma "universidade da saúde". Novamente, o tema cede lugar para o próximo acontecimento narrado. $\mathrm{O}$ texto termina no período contemporâneo, em que o projeto de fazer da EPM uma universidade estava em fase de adaptação e execução. Mencionava-se a visita do ministro da Educação, José Goldemberg, e a sua opinião favorável ao processo. O capítulo encerra-se transcrevendo as boas avaliações que os cursos de Medicina, Ciências Biomédicas, Fonoaudiologia e Enfermagem teriam conseguido ao serem comparados com mais de 3 I 7 outros cursos no país. Também eram mencionadas as notas que a Capes teria atribuído ao curso de pós-graduação, atestando sua excelência. As palavras con-
I35. A esse respeito, ver capítulo III.

136. Escola Paulista de Medicina: 60 Anos de História, pp. I8-19.

I37. Idem, p. 22. 
clusivas referem-se ao progresso ocorrido nesses sessenta anos, desvelado como um sonho que se realizou, graças ao "invulgar entusiasmo" daqueles 33 "jovens", que tiveram a coragem de fundar a I I $\underline{\underline{a}}$ escola médica do Brasil ${ }^{138}$.

O epíteto "jovem" não era fortuito. Ele transpira os ideais de energia e força. Se verificarmos as datas de nascimento dos 33 fundadores, vemos que 24 nasceram entre I 890 e I 90 I. Ou seja, estavam quase no meio da década dos trinta e quarenta anos, portanto indo para uma idade mais madura. Dentre os 33, sete nasceram entre 1902 e $1907-$ estes sim, mais jovens. Já entre os mais velhos, há somente dois: Henrique da Rocha Lima, nascido em 1879, cinco anos antes de Lemos Torres, de I884, que em 1933 beirava os cinqüenta anos. A média de idade dos 33 fundadores ficava em torno dos 36 anos.

O livro comemorativo dos sessenta anos náo contém fotografias. Os capítulos são precedidos de uma página que leva o título dos mesmos e um desenho de alguma edificação histórica ou de construção mais recente da EPM. O leitor, porém, náo fica sabendo quem foram os autores dos desenhos.

A obra distingue-se pela enorme quantidade de informaçóes que apresenta. No entanto, ela dificilmente vai além da preocupação de tratar os fatos históricos em ordem cronológica, sem indicação concreta das fontes. A linearidade do critério cronológico sobrepóe-se à perspectiva temática. Questôes bastante delicadas figuram ao lado de outros acontecimentos menos relevantes ou complexos, sem estabelecer com eles qualquer relação. O que reina é o eixo cronológico e o desencadear dos acontecimentos que, ao fim e ao cabo, resultaram numa história gloriosa - um sonho realizado.

Os problemas, quando mencionados, são atribuídos a forças e circunstâncias exteriores à Escola (as crises financeiras, o golpe de 1964, os IPMS, a cassação de Lindenberg, a extinção da UFSP), enquanto os louros são atribuídos aos fundadores e continuadores da obra da fundação (os êxitos científicos, a construção do HSP, o vigor geracional constantemente renovado a partir da inspiraçáo vinda das origens quase míticas da EPM). Em consonância com os livros anteriores, a EPM figura sempre como caminhante solitário, excluindo comparação com outras instituiçóes.

Ao longo das comemoraçóes, as atividades culturais voltaram-se às apresentaçốes de canto-coral, concertos e shows. Novamente montouse uma mostra visual, apresentando a arte e artistas nos sessenta anos de existência da Escola. A isso se acrescenta o lançamento de Fatos Pitorescos na Vida de um Médico Paulistano, de Jorge Michalany, professor 
e ex-aluno da EPM. Na área médica, a programação científica propiciou debates sobre os avanços da medicina, coordenados por Eduardo Katchburian, por meio da apresentação de trinta trabalhos das disciplinas integrantes dos departamentos de ensino. Conforme antecipara o Jornal da Paulista, a EPM "comemora os sessenta anos de sua fundação", aproveitando a oportunidade para mostrar o melhor da pesquisa, ensino e prestação de serviços. Este seria o momento das disciplinas mostrarem o que estavam produzindo de "mais moderno" no tocante às novas técnicas e descobertas ${ }^{139}$. Como atividades paralelas, realizaramse uma reunião do Conselho de Diretores das Instituições de Ensino Superior Federais Isoladas (Codesfi) e o II Congresso da Rede de Projetos de Integração Docente Assistencial (Rede IDA-Brasil).

$\mathrm{O}$ encerramento se deu em I 8 de junho, após competiçóes esportivas de várias modalidades (futebol de campo e salão, vôlei, basquete, handebol, natação, judô, tênis de mesa e campo, xadrez, corrida de sete mil metros por Vila Clementino ${ }^{\mathrm{I40}}$ ), festa junina e um concurso de Miss Escola Paulista de Medicina, em jantar de confraternização no Esporte Clube Pinheiros ${ }^{\mathrm{I} 4 \mathrm{I}}$.

Essa seria a última grande efeméride da ЕРM enquanto escola superior federal isolada. Desde I966, com a criação do curso biomédico, a perspectiva de voltar a ser uma universidade entrava com alguma freqüência na pauta de discussóes, ganhando contornos mais viáveis em I 5 de dezembro de I994, quando a EPM foi transformada em universidade ${ }^{\mathrm{I} 42}$.

\section{Setenta Anos de epm e Nove de Unifesp}

Em 2003, ao completar setenta anos, a EPM transformara-se em Unifesp (I994), uma universidade temática focada nas ciências da saúde $^{\mathrm{I} 43}$. Diferentemente das efemérides anteriores, as comemoraçôes ocorreram em dezembro e não no meio do ano. Mas, para não escapar da memória do mês fundador, o Jornal da Paulista iniciou, em julho, uma série de matérias contendo depoimentos de profissionais da área médica e da saúde ligados à Unifesp. A série inicia-se com um singelo "Parabéns, Unifesp" e, logo abaixo do título, algumas informaçóes quantitativas sobre a instituição naquele momento:

Aproximadamente $\mathrm{I} 42 \mathrm{mil} \mathrm{m}^{2}$ de área ocupada, 348 cursos e programas de especialização e aperfeiçoamento e mais de doze mil alunos, incluindo os de ensino à distância. A Escola, que começou em um único prédio, em I933, hoje ocupa cerca de 260 propriedades em setenta anos de história que marcaram o ensino, a pesquisa e a assistência no país" ${ }^{\text {I44. }}$
I39. “Avanços na Medicina. Dr. Katchburian, Coordenador dos Avanços na Medicina”, Jornal da Paulista, 6 (64), abr. I993, p. Iо.

I40. "Atividades Esportivas - Escola Paulista de Medicina, 6o Anos", idem.

I4I. Programação oficial e científica comemorativa dos 60 anos de fundaçáo da Escola Paulista de Medicina. Brochura. Acervo do cehri, pasta nํㅡ 4 - Aniversário: 40 e 60 anos da EPM.

I42. Ver capítulo IV.

I43. Sobre a construçấo da idéia de "Universidade da Saúde", ver capítulo iv.

I44. "Parabéns Unifesp", Jornal da Paulista, I6 (I8I), jul. 2003. 
I45. Depoimento de Valéria Petri, professora titular de Dermatologia Infecciosa e Parasitologia. Jornal da Paulista, I6 (I8I), jul. 2003.

I46. Emil Burihan, formado em 1956 pela EPM, professor titular da Unifesp. Jornal da Paulista, I6 (I82), ago. 2003; Roque Monteleone, livre-docente pela usP e professor na Unifesp, Departamento de Informática. Jornal da Paulista, I6 (I85), nov./dez. 2003.

I47. Roque Monteleone. Jornal da Paulista, I6 (I85), set. 2003.

I48. Eleonora Menicucci de Oliveira, professora livre-docente da Disciplina de Ciências Humanas em Saúde do Departamento de Medicina Preventiva. Jornal da Paulista, I6 (I83), set. 2003.

I49. Lydia Masako Ferreira, formada pela então Escola Paulista de Medicina em I976. Professora titular da Disciplina de Cirurgia Plástica da Unifesp e coordenadora do programa de pós-graduação em cirurgia plástica reparadora. Jornal da Paulista, I6 (I83), set. 2003.

I50. De lá saiu a primeira tese de doutoramento defendida na escola, em I954. Na década de I970, os dois lideraram a criação de um dos primeiros programas de pós-graduação paulista, reconhecido pelo MEC em I97 I. Antonio Cechelli de Mattos Paiva, professor titular aposentado de biofísica, membro do Núcleo de Desenvolvimento Cultural e Científico da Unifesp. Jornal da Paulista, I6 (I84), out. 2003.

I5I. A seu ver, cruciais foram a criação do Departamento de Clínica Médica, depois denominado Departamento de Medicina; o início formal da pós-graduação lato sensu, representado pelo programa de residência médica do HsP, e a consolidação da pesquisa. No ensino, ela lembrou a relevância da Secção de Metabolismo e Nutrição, da Clínica Médica, posteriormente Disciplina de Nefrologia. Sublinhou o trabalho pioneiro da geração dos anos de I960 na captação de recursos externos para a investigação científica e em políticas de formação de pesquisadores para realizar preferencialmente estágios no ex-
Onze depoimentos foram publicados, dentre eles o de Jair Xavier Guimarães, última testemunha da época da fundação. Neles, condensaram-se aspectos das sete décadas, nos quais enfatizaram-se as vocaçôes dos professores das primeiras geraçóes epemistas, as transformaçôes nas competências médicas, científicas e didáticas, bem como os momentos de mudanças institucionais que contribuíram para o seu avanço. Uma ex-aluna formada em I973 e tornada professora titular relembrava: "A história da EPM foi marcada, desde o início, pela formaçáo de profissionais com perfil típico: clínicos de família e cirurgiôes com forte senso clínico. No final dos anos sessenta, vieram os biomédicos e depois, a revoluçấo da Biologia Molecular" "45.

O paulatino crescimento da área física, a introdução da pós-graduação em $1972^{146}$, a federalização $0^{147}$ e a transformação da Escola em "Universidade da Saúde" são considerados pontos de absoluta inflexão pois, a partir deles, deram-se mudanças radicais na área de saúde coletiva e saúde pública, que se manifestaram numa maior visibilidade social da instituição de ensino. A Unifesp contribuiu para a implantação do Sistema Único de Saúde (sus) e dos distritos de saúde-escola ${ }^{148}$. De forma sucinta, Lydia Masako Ferreira apresentou as "proposiçôes acertadas" da Unifesp:

I) o prédio de pesquisa, que tem permitido avanço técnico-científico; 2) vanguarda na geração e distribuição de conhecimentos; 3) aumento na captação de recursos, por meio de instituiçóes de fomento e da integração com empresas; 4) vanguarda na pós-graduação stricto sensu; 5) qualidade de ensino na graduação; 6) integração da universidade com a comunidade; 7) atuação da área de comunicação, o que permite maior vínculo entre os profissionais e a sociedade ${ }^{\mathrm{I} 49}$.

Para o Antonio Cechelli de Paiva, o "divisor de águas" que transformou academicamente a EPM em universidade, focando sua atividade na pesquisa e na pós-graduação, ocorreu quando os professores José Ribeiro do Valle e José Leal Prado transferiram-se do Instituto Butantan para fixar-se com dedicação exclusiva nas disciplinas de Farmacologia e de Química Biológica da EPM e montaram seu laboratório de pesquisa no $\mathrm{HSP}^{\mathrm{ISO}}$. Regina Stella reiterou a importância dos anos de I950/I 960, sementeira do que viria a ser a universidade. Reafirmando a história contínua, sem rupturas e crises, que cresce e se desenvolve naturalmente, ela ponderou: "A árvore plantada em I933 enraizou-se. Não parou de crescer no ensino, na produção científica, na atenção à saúde e nas açôes sociais" ${ }^{\prime \prime I}$. 
A efeméride não se encerrou com essas sínteses históricas, relatos das experiências e memórias de pessoas que vivenciaram e construíram a instituição. Tal como em comemoraçóes anteriores, os festejos se desdobraram em atividades sociais, culturais e esportivas. Junto a essas atividades, organizou-se uma campanha incentivando a solidariedade, em que se arrecadou I, 5 tonelada de alimentos não perecíveis em prol do Fundo Social de Solidariedade do Estado de São Paulo e dos hospitais que fazem parte do Complexo Unifesp/spdm. Igualmente, a Unifesp fez um apelo para estimular a doação voluntária de sangue no Hemocentro do Hospital São Paulo.

Em sessão solene do Conselho Universitário em is de dezembro de 2003, Durval Rosa Borges proferiu discurso em homenagem aos setenta anos da Unifesp/EPM, focando sua história ${ }^{\mathrm{Is} 2}$. Dividida em nove estações, essa história igualmente norteou-se pelos momentos considerados decisivos, seguindo um eixo cronológico. A "primeira estação" versava sobre a fundação, destacando a passagem do Manifesto de Fundação ( I o de junho de I933), em que se apontavam as carências do ensino médico e da assistência hospitalar em São Paulo. Essa falta deveria ser coberta por uma escola médica com instalaçóes hospitalares. Conforme comentou Rosa Borges, o que atualmente parece óbvio era bastante inovador naquele momento: unir escola médica com hospitalescola. Lembrou também do lançamento da pedra fundamental da construção do HSP e citou as já tão conhecidas palavras do poeta Guilherme de Almeida. Essa seria a etapa voltada para o ensino profissionalizante e a assistência médica.

A “segunda estação", denominada Pampulha, seria marcada pelo edifício que atualmente leva o nome de José Leal Prado. Este lugar foi identificado como o berço da pesquisa da EPM e, depois, da Unifesp. Borges reiterou os comentários publicados no Jornal da Paulista acerca da vinda dos mineiros José Ribeiro do Valle e José Leal Prado para a Escolinha, decisiva para dar início às atividades de pesquisa e ao trabalho em laboratório. Pampulha era a alcunha carinhosa dada ao prédio onde os dois médicos cientistas instalaram em I956 o Laboratório de Farmacologia e Bioquímica, depois de ter vivido seus primeiros passos no anexo à farmácia do HSP. Frutos dessa etapa foram os departamentos de Bioquímica, de Farmacologia, de Biofísica e de Psicobiologia. A "terceira estação" tem como marco a criação do Departamento de Medicina, em r95 I e, com isso, o lento desmantelamento do regime de cátedras e a implantação de novas disciplinas (Cardiologia, Endocrinologia, Gastroenterologia, Hematologia, Pneumologia e Propedêutica Médica). O departamento ficava sob a chefia de um professor titular e terior. A criação do Instituto de Medicina Preventiva, na mesma década, também foi destacada. Regina Stella, doutora em Medicina, diretora do Departamento de Comunicação da Unifesp, vice-reitora da universidade entre I995 e 1999. Jornal da Paulista, I6 (185), nov./dez. 2003.

I52. Durval Rosa Borges, "Até Aqui Viemos", Jornal da Paulista, I6 (I86), jan. 2004. As citaçóes a seguir remetem a este documento. Durval Rosa Borges é professor titular do Departamento de Medicina da Unifesp e diretor do Laboratório de Hepatologia Experimental. Foi pró-reitor de graduação e atualmente é presidente da Fap. 
I53. O Edifício de Pesquisa II foi inaugurado em 2007. Na ata do Consu de I3 de junho de 2007, lê-se acerca da inauguraçâao do prédio, em I 4 de junho. Ata da reunião ordinária do Consu, I3 jun. 2007. Ver também "Edifício de Pesquisas II Ampliará Produçẫo Científica”, Jornal da Unifesp, I5 jun. 2007, p. 7. era regido por um conselho. A “quarta estação" seria a da federalização. Sem rodeios, Borges expressou o quanto a questão foi polêmica na época e acirrada a votação a seu favor na Congregação (catorze votos a favor, treze contra). A separação entre a EPM então federalizada e o HSP, que ficaria sob a administração da SPDM (I 960), não interferiu em sua vocação de ser o hospital-escola da EPM. Esta parceria surgia como um "modelo único" no país e muito útil, quando não salvador. Na estação "desencontros", o autor comentou o malogro da UFSP (Universidade Federal de São Paulo), que deveria iniciar seu funcionamento em I 964. "A UfsP foi desfeita e Marcos Lindenberg cassado. Hoje existe a Unifesp e Marcos Lindenberg dá nome a este teatro onde nos reunimos". Com alívio, reconheceu que, apesar das vicissitudes históricas, a EPM não sofreu o desmembramento físico e espacial em virtude da separação dos departamentos de ensino profissional daqueles de ensino básico. Esta era a tendência das universidades públicas em voga, conforme reforma proposta pelo governo. Com isso, a EPM manteve o seu espaço físico e sua identidade nas ruas da Vila Clementino, conferindo-lhe mais uma característica especial.

As duas estações seguintes dedicavam-se à criação da Unifesp, embora abrangessem um intervalo de quase vinte anos. A criação do curso biomédico em I 966 é tida como embrião da Unifesp. Rosa Borges reproduziu as palavras de José Leal Prado, que naquela ocasião vislumbrava a retomada da universidade abortada por meio da experiência do novo curso. Com ele, as atividades da EPM iriam se expandir e forneceriam o insumo para um novo projeto universitário. $\mathrm{O}$ salto temporal do palestrante chega a I994, com a transformação da EPM em Unifesp, sétima estação da história institucional. Sublinhava-se mais uma especificidade da instituição: tratava-se de uma "universidade temática”, organizada em departamentos acadêmicos coordenados por pró-reitorias específicas.

Um novo modelo de pesquisa em laboratório concretizou-se com a inauguração, em I 995, do Centro de Pesquisas Clínicas e Cirúrgicas Oswaldo Ramos. Este era o marco da oitava estação, e sua relevância era explicada pelo fato de esses laboratórios não pertencerem a nenhum grupo, disciplina ou departamento. Seu uso advém do mérito e da produtividade do grupo de pesquisa, em contínua avaliação. Modelo tão profícuo que motivou o projeto para mais um edifício de pesquisa ${ }^{153}$. Esses fatos suscitam avaliaçôes positivas, colocando a instituição em destaque, expressas por Borges: "Os edifícios foram sempre conseqüência, e não causa, do esplêndido desenvolvimento da pós-graduação e da pesquisa nesta Casa, líder nacional na área biomédica”. 
A nona e última estação ganhou o epíteto de "a reordenação". Vale a pena reproduzir as palavras de Rosa Borges:

Vivemos período de reordenação, após grande expansão. Novos estatutos da Unifesp e da spdm foram aprovados. Pela primeira vez o Regimento Geral da Unifesp faz referência à spDM e o estatuto desta determina que a SPDM tem como objetivo geral apoiar a Unifesp em suas atividades de ensino, pesquisa e extensão. Ao longo dos anos criaram-se, a partir de departamentos acadêmicos, instituiçôes suplementares. Exemplifico apenas as maiores: Fundação Oswaldo Ramos, Instituto do Sono, Instituto da Visão, Instituto de Diagnóstico por Imagem e o Instituto de Oncologia Pediátrica. A sPDM não mais se limita ao HsP: gerencia os hospitais Vila Maria, Pirajussara, Diadema, Cotia, Salto e o Programa de Saúde de Família. A Colsan incorporou-se à Unifesp. São socialmente relevantes nossos programas de extensão: Xingu, Quixote, Cananéia, Pida-Embú, Favela, UATı. O Consu em sua última reunião ordinária de 2003 aprovou a idéia de criação de uma Fundação, que se for denominada Escola Paulista de Medicina, perpetuará formalmente este nome que nos emociona.

Sabemos que a fundação foi criada, porém com outro nome - Fundação de Apoio à Unifesp (Fap). Nas palavras de encerramento, Borges citou um trecho d'Os Lusíadas, de Camóes, evocando a semelhança da viagem exploratória pelo mundo afora com a trajetória da Unifesp/ EPM. Interpretou o que a "história" da instituição ensinou, dando-lhe um sentido e identidade:

Nossa história mostra sempre a iniciativa antecedendo a existência de recursos. Sabemos que não existe criação sem tradição que a nutra, assim como não existe tradição sem criação que a renove. Portanto tornaremos a seguir nossa longa rota com o espírito que animou nossos homenageados de hoje.

O que se nota nestas construções históricas, incluídas as passagens testemunhais publicadas no Jornal da Paulista e as estaçóes de Rosa Borges, é uma nítida preocupação de marcar momentos que suscitaram mudanças no funcionamento da instituição, em que se reiteram vocaçóes positivas, que afirmam a pertinência, a coerência e as competências do trabalho e do desenvolvimento da instituição. Ao mesmo tempo, procura-se não insistir nas fragilidades - ou melhor, elas quase sempre são reveladas somente depois de superadas. Exemplo disso é a forma como é narrado o processo de federalização. Há igualmente uma 
154. Ana L. Guímaro e Leonel Prata (eds.), A Universidade da Saúde: Escola Paulista de Medicina, 70 Anos.

I55. "Instituição Faz 70 Anos e Presenteia a Comunidade", Jornal da Paulista, I7 (I86), jan. 2004.

156. "Criada em novembro de 1984, a Gabarito [de Marketing Editorial] é especializada em comunicação empresarial. Produz projetos jornalísticos, institucionais, promocionais, educacionais e de treinamento para diversas empresas brasileiras". Em sua lista de clientes, encontram-se empresas médicas e um bom número de indústrias farmacêuticas. Cf. http://www.gabaritoeditorial. com.br, acesso em dez. 2007.

157. O conselho editorial foi integrado por Durval Rosa Borges, Helena Nader, Regina Stella, Ricardo Luiz Smith e Dante M. Claramonte Gallian; entre os colaboradores, Márcia Regina Barros da Silva.

I58. A publicação apresenta mais de noventa imagens, dentre elas, quase um terço datam do período da fundação até o final dos anos de 1940. Do restante, a maioria são fotografias recentes, que mostram cenas de trabalho (em aula, no laboratório, no atendimento etc.) na Unifesp/EPM, instalaçōes e equipamentos (prédios, salas especializadas) e algumas personalidades importantes da instituição. forte tendência de sublinhar a singularidade da instituição, empregando os termos "pioneiro", "modelo único" ou "pela primeira vez", sem que sejam estabelecidas comparaçóes com outras instituiçóes da mesma natureza. Nesse sentido, mais uma vez a instituição parece como uma individualidade que traça seu caminho de forma solitária, reafirmando a sua aura heróica.

$\mathrm{O}$ aniversário de setenta anos também ensejou o lançamento de um livro comemorativo ${ }^{\mathrm{I} 54}$, cujo lançamento ocorreu no recém-reformado Teatro São Pedro, em noite de gala, que teve como atração a Orquestra Filarmônica dos Médicos do Hospital Israelita Albert Einstein ${ }^{155}$.

Essa foi uma obra de encomenda e realizada por uma empresa de comunicação $^{156}$, especializada na realização de livros comemorativos para empresas e instituiçóes. Diferentemente, portanto, dos livros anteriores e do que o Jornal da Paulista veiculou, os autores dessa edição não fazem parte da instituição, embora fossem supervisionados por um Conselho Editorial formado por professores da Unifesp e de colaboradores $^{157}$. Os textos foram redigidos por Roberto Guimarães, que assumiu a pesquisa histórica, enquanto Cristina Thomaz coletou os depoimentos. Outra novidade reside no aspecto visual da obra. Um projeto gráfico acurado, o grande número de reproduçóes fotográficas ${ }^{158}$, a boa qualidade de impressão, bem como o formato $\mathrm{A}_{4}$, demonstram uma estética preocupada em agradar o leitor, atraindo o interesse e facilitando a leitura. Igualmente algumas soluçóes gráficas como, por exemplo, uma tabela cronológica, no início do livro, citando alguns fatos históricos ao lado de uma periodização indicando as fases da EPM (e depois da Unifesp/EPM) e que segue no topo de cada página, ajuda o leitor a se localizar no tempo.

Livros comemorativos anteriores priorizaram as biografias e a estrutura institucional da EPM, focados isoladamente, e os acontecimentos retidos em atas e expostos de forma cronológica. Já no trabalho em questão, a história da instituição foi tratada em quatro etapas, balizadas por eventos específicos, sublinhando as transformações. Como o livro dos sessenta anos, também este oferece ao leitor numerosas informações, com o diferencial da maior preocupação em contextualizar a EPM no cenário da história nacional. Apesar dessa perspectiva, não se explicitam os aspectos metodológicos e tampouco indicam-se as fontes e a bibliografia utilizadas. Ao leitor não se evidencia de que forma as informaçóes, os depoimentos e as imagens foram colhidas, processadas e incorporadas no texto. Ao contrário do livro comemorativo dos quarenta anos, as biografias dos personagens mais relevantes fluem no texto sem assumir um destaque especial, ou seja, os aspec- 
tos biográficos foram inseridos no arrolar dos acontecimentos. O que continuou a prevalecer foi o forte enfoque nos docentes, obliterando a participação dos demais funcionários no processo de construção e funcionamento institucional.

A história da "Universidade da Saúde" divide-se em quatro momentos, que estruturam os capítulos do livro. O primeiro, "Do Início Heróico à Federalização da Escola Particular”, cobre os anos de I933 a I956. Boa parte do capítulo é dedicada ao período da fundação da EPM. Se o Manifesto desta vez não foi publicado na íntegra, há o nítido objetivo de explicar ao leitor a relação entre os acontecimentos históricos atrelados ao movimento de 1932 e a criação da instituição. Em outras palavras, o que nos textos anteriores aparecia como uma relação tácita ou explícita, mas mais superficialmente, aqui é abordada detalhadamente no contexto político nacional. Nesse sentido, reitera-se o discurso da fundação em que se ressalta a questão paulista de maneira mais fundamentada. A epígrafe do capítulo assume, então, pleno sentido. A já muitas vezes citada passagem de Guilherme de Almeida, quando do lançamento da pedra fundamental do HSP, em 30 de setembro de I936: a derrota da Revolução de 1932 diante de Vargas dá ensejo para exaltar a força de São Paulo, "de armas vencidas e almas vencedoras" e que lançou uma "semente milagrosa": a EPM" ${ }^{159}$.

O capítulo seguinte narra o processo de profissionalização da Escola e sua expansão ao campo da pesquisa, entre 1956 e i966. A federalização e a contratação de catedráticos em tempo integral teriam sido o diferencial que fez da EPM um curso formativo e não mais somente informativo. A introdução do curso de Ciências Biomédicas em I 966 foi vista como "iniciativa pioneira" e figura como "embrião da Unifesp", possibilitando a formação de pesquisadores na área básica ${ }^{160}$. Mas também é nessa etapa que ocorre o fiasco da integração da EPM à UFSP: o período de "turbulenta crise nacional" ganhou mais espaço do que nos livros anteriores. Comenta-se a greve de dois meses, de I962, iniciada pelo Centro Acadêmico a favor da federalização do HsP, incluindo uma marcha a Brasília. Os alunos grevistas foram recebidos pelo então presidente do Congresso, Auro de Moura Andrade, e pelo primeiro-ministro Tancredo Neves, por quem foram convencidos a terminar a paralisação com a promessa de federalização que nunca fora cumprida ${ }^{161}$.

Nesse livro, o 3 I de março de I964 não foi considerado um "movimento", mas sim designado de "golpe militar", e a época é focalizada com mais pormenores ${ }^{162}$. Outro aspecto abordado foi a participaçáo dos alunos. De um lado, lembra-se o fato de ter havido estudantes que "exerciam a inglória função de arapongas", avisando o Deops sobre
159. Ana L. Guímaro e Leonel Prata, op. cit., p. 9.

I60. Idem, p. 45.

I6I. Idem, p. 39. Ver também o capítulo III.

I62. Além dos casos do afastamento forçado de Marcos Lindenberg e da perseguição ao entấo presidente do CAPB (Walter Albertoni), menciona-se o desaparecimento do aluno boliviano conhecido como "Azulão", que participava de um programa de bolsas financiadas pelo Itamaraty. Idem, pp. 39-40. 
163. Ana L. Guímaro e Leonel Prata (eds.), op. cit., p. 4I. Em 26 de outubro de 1964 ocorreu o show "O remédio é bossa”, organizado pelo C. A. Pereira Barretto, no Teatro Paramount, sob a direção de Walter Silva. Foi a primeira apresentação de Tom Jobim ao vivo, em São Paulo. Elis Regina cantou com Marcos Valle a música Terra de Ninguém (Marcos Valle e Paulo Sérgio Valle). Cf. http://www.geocities.com/altafidelidade/eng_crono.htm e http://www. dicionariompb.com.br/detalhe.asp?nom e=Elis+Regina\&tabela=FORM_A\&qdet alhe=art, acesso em fevereiro de 2008. Segundo Marcos Napolitano, de 1965 até I969, a onda dos festivais em que a música engajada tornou-se a preferida do júri e do público (em São Paulo, TVs Excelsior e Record, e no Rio de Janeiro, a Globo) é precedida por uma fase de shows freqüentados por uma maioria estudante, que acabou por expandir este gênero musical: o show "Opiniáo" (1964), o espetáculo "Arena Canta Zumbi” (1965), bem como os shows realizados no Teatro Paramount de São Paulo entre 1964 e 1965, patrocinados por centros acadêmicos universitários. Cf. http://www.geocities.com/altafidelidade/eng_ensa.htm, acesso em fevereiro de 2008 .

I64. Idem, p. 49.

165. Destacam-se inicialmente a criação da Bireme, dos cursos de graduação de Fonoaudiologia, de Ortóptica, do Programa de Integração Docente Assistencial do Embu (Pida-Embu), iniciativa do Departamento de Pediatria. Idem, p. 53 .

I66. Idem, p. 57.

I67. Idem, p. 6I. reunióes políticas. De outro, o Centro Acadêmico surge no contexto como força ativa contra a repressão. Em I 964, os alunos da EPM organizaram o show "O Remédio é Bossa”, onde se apresentaram nomes como Vinícius de Moraes, Nara Leão, Tom Jobim e Elis Regina ${ }^{163}$. O tema espinhoso da repressão não foi omitido; no entanto, pouco se sabe, até hoje, sobre como a censura e a perseguição foram organizadas e executadas no interior da instituição.

O capítulo seguinte, que cobre o período de I966 a I994, é considerado o da gestação da Universidade da Saúde. O contexto continua sendo o da repressão política radicalizada - o AI-5, desde dezembro de I968, e a presidência de Emilio G. Médici, desde I969. A dedicação da EPM ao trabalho acadêmico-científico é interpretada como uma opção para escapar construtivamente da radicalização política, o que resultou na efetiva gestação da Unifesp ${ }^{164}$. Os componentes dessa gestação são arrolados e descritos em suas funçóes e importância para o fortalecimento institucional ${ }^{165}$. Além disso, a crescente experiência na pesquisa e nos cursos de pós-graduação, que surgiram em i970. O trabalho de pesquisa de Leal Prado e José Ribeiro do Valle na área biomédica e de Oswaldo Ramos, na área clínica, são vistos aqui como decisivos para o desenvolvimento do saber científico na instituição. Igualmente, alude-se a uma crescente "meritocracia" dos profissionais que seguiram a carreira acadêmica. Os postos somente foram atingidos por meio de um criterioso processo seletivo ${ }^{166}$.

Enfatiza-se o trabalho das décadas de I970 e I980: a inauguração do prédio da administração central, o Edifício Octávio de Carvalho, em I978; a criação do Instituto de Farmacologia e Biologia Molecular (Infar), em I 983; a ampliação do HSP e a criação Centro de Informática em Saúde (CIs), concluindo: "Ao desenvolver um bem-sucedido modelo de ensino, pesquisa e assistência, a EPM deu o último e mais importante passo rumo à sua concepção de universidade. Estava concluída a gestação da Universidade da Saúde" ${ }^{167}$.

A última etapa, intitulada "Universidade da Saúde", oferece ao leitor um amplo panorama do desdobramento da EPM em universidade da saúde. Para um período de nove anos, de I 994 a 2003, são arroladas tanto as mudanças de organização institucional (como a formação da reitoria e as pró-reitorias) como a de status. Uma vez universidade, a Unifesp conquistou assento em órgãos como o Conselho de Reitores das Universidades Brasileiras (CRUB) e a Associação de Dirigentes de Instituições de Ensino Superior (Andifes). Desde então, a instituição também ganhou autonomia para expedir diplomas e criar novos cursos. Também houve a criação da TV Unifesp, a implantação e/ou amplia- 
ção de programas de extensão universitária e foram criados os órgãos complementares, que exercem a função de expandir as atividades da Universidade da Saúde. Descrevem-se resumidamente as atividades dos centros e dos institutos recém-criados, ressaltando sua importância e os objetivos no contexto da ciência médica e da saúde pública ${ }^{\mathrm{I} 68}$.

O forte enfoque na história factual da instituição inserida num contexto mais amplo tem seus momentos de refúgio. Lembrando a edição comemorativa d'O Bíceps em I 943 e distanciando-se dos livros comemorativos anteriores, acrescentaram-se passagens de 29 depoimentos de ex-alunos e professores da Unifesp/EPM (das turmas de 1938 a I 999), separadas do corpo do texto. Esses depoimentos, cujos personagens são em sua maioria identificados somente pelo nome e o ano de formatura na escola, ultrapassam o caráter informativo do texto, introduzindo uma percepção subjetiva dos acontecimentos. $\mathrm{O}$ recorte selecionado reitera a experiência positiva e edificante de se ter passado ou ter se dedicado a Unifesp/EPM sob vários prismas.

Algumas impressóes podem ser depreendidas dessas passagens. Em muitas delas, a EPM é comparada a uma família, com a qual se sela um laço emocional e afetivo que se estende por geraçóes. As vivências na Escola, quando ela ainda era jovem, sublinham a questão da filantropia dos professores e da solidariedade entre professores e alunos frente às incertezas. Outro aspecto que se reitera é a concordância quanto à excelente qualidade do ensino que transcenderia a carreira médica, fazendo da EPM uma escola da vida, cujos professores náo eram apenas médicos e cientistas, mas também mestres que formavam o profissional e o ser humano. Não faltam mençôes à seriedade da instituição, ao seu ambiente científico estimulado pelos professores e o coleguismo. Para alguns, o período de formação na EPM é tido como a melhor época de suas vidas. A EPM também figura como lugar de aprendizado social, pela convivência estudantil e o estímulo ao esporte. E de aprendizado político, sobretudo durante a ditadura, por meio das atividades do САРB e dos protestos realizados. Evidentemente, em nenhum dos depoimentos há uma exposição negativa a respeito da instituição ou de seus docentes; ao contrário, os professores são vistos como tolerantes, dedicados, interessados, competentes e sérios. O depoimento mais recente sintetiza bem esses aspectos, sublinhando o quanto a própria instituição é capaz de gerar o sentimento de pertencimento a uma comunidade, conferindo ao indivíduo uma identidade, que se perpetua no tempo:

A Escola Paulista de Medicina me adotou em I994 e, desde então, tem sido palco, lar, testemunha, cenário, agente de tantos e táo diversos aconteci-
168. Ana L. Guímaro e Leonel Prata (eds.), op. cit., p. 65. Centro de Desenvolvimento do Ensino Superior em Saúde (Cedess), Centro de Incentivo e Apoio ao Aleitamento Materno (Ciaam), Grupo Multidisciplinar de Oncologia (GMo), Centro de Genética Médica, Centro de Diabetes, Centro de Microscopia Eletrônica (CEME), Centro de Referência em Erros Inatos do Metabolismo (Creim), Centro de Desenvolvimento de Modelos Experimentais para Medicina e Biologia (Cedeme), Centro de História e Filosofia das Ciências da Saúde (cenri) (p. 74), Centro Alfa de Habilidades e Atendimento (p. 87), Centro de Informática em Saúde (cis) (p. 88). E os institutos, que atuam em parte em parcerias: Instituto da Visão, Instituto do Sono, Instituto de Pesquisa e Estudo de Diagnóstico por Imagem (IDI), Grupo de Apoio ao Adolescente e à Criança com Câncer (Graac), órgão conveniado à Unifesp. 
mentos de minha vida - é impossível falar de mim e da minha identidade sem mencioná-la. Como médica, digo que ter me formado pela Paulista faz toda a diferença. Há o privilégio de conviver com pessoas, entre colegas e mestres, que conseguem conciliar a rara combinação de inteligência e humanismo [...] Há uma incrível estrutura de suporte ao aluno, que me proporcionou desde a bolsa de iniciação científica [...] até a possibilidade de comparecer a diversos congressos, sempre representando a Escola com muito orgulho. Dessa forma, justifico com tranqüilidade a minha insistência em nela continuar: ser epemista é um estado de espírito que, uma vez alcançado, é impossível de se desfazer”.69.

As palavras finais do livro, no entanto, desvelam uma situação tensa, gerada, por um lado, pelo crescente desafio que é manter atualizado o ensino, a pesquisa e a extensão diante dos enormes avanços da ciência da informática e da tecnologia digitalizada, e, por outro, pela falta de recursos que assolam as universidades públicas, sobretudo, as federais. Ou seja, acompanhar as novidades no campo das ciências e manter o padrão de excelência pelas próximas geraçóes parece tarefa quase irrealizável:

Nos últimos anos, uma combinação perversa de fatores - achatamento salarial, aposentadoria compulsória de diversos docentes, ausência de concurso para contratação de novos professores e concorrência das faculdades e universidades privadas, que atraem novos talentos por seus salários mais competitivos, entre outros - impediu a renovação do corpo docente da Unifesp/EPM ${ }^{170}$.

Diante desse quadro incerto, dúvidas quanto à manutenção de um corpo docente se impunham. A solução desse "gravíssimo problema”, assim sugere-se, pode ser "buscada na própria história da Escola Paulista de Medicina”. Semelhante, aliás, ao que Durval Rosa Borges fez em suas "estaçóes" sobre o passado da EPM, a história dela serve aqui como lição e inspiração para resolver o presente e projetar o futuro. Acompanhemos as palavras heróico-proféticas que encerram o livro: "Mais do que nunca, é preciso coragem para empreender. E, sobretudo, ousadia para inovar. Pensar grande. Hoje. E sempre" ${ }^{171}$.

169. Flavia Saori Miyashira, turma de 1999. Idem, p. 89 .

I70. Idem, p. 91.

I71. Idem, ibidem.

\section{Consideraçóes Finais}

Ao investigar as comemoraçóes da EPM e da Unifesp, pode-se falar quase de uma migração do ato de homenagear a instituição, recolher a sua memória e escrever a sua história, que se inicia com o СAPB e depois é transferido para a própria EPM. Vimos que as primeiras efemérides, a de 
dois e a de dez anos, foram em grande parte organizadas pelo Centro Acadêmico, sendo que suas principais contribuiçôes foram as ediçôes especiais dos jornais $O$ Átomo e, depois, O Bíceps. O mesmo vale para o jubileu de prata, em que a edição comemorativa d'O Bíceps preenche o vácuo criado pela própria EPM - o livro comemorativo solicitado a Albernaz pelo CTA se atrasa por uma década e a própria instituição, naquele momento atravessando uma fase crítica, praticamente não se festeja. Já a partir do aniversário de trinta anos, о САРв permanece na retaguarda das comemoraçóes. Se no editorial do segundo número d' $O$ Átomo, que pode ser entendido como porta-voz do Centro Acadêmico, revelava-se o objetivo de homenagear e venerar para sempre a Ерм e seus docentes, a situação na década de 1960 era outra. A politizaçấo dos jovens, a contra-cultura, os movimentos de esquerda e as ameaças políticas causadas pelo golpe militar de 1964 se expressam na conduta e no papel que o СAPB ocupava na instituição. A partir desse período, nota-se que a EPM incumbe-se cada vez mais de organizar os seus aniversários. Vale notar que aqueles que outrora haviam sido alunos da Escola e, em alguns casos, atuaram também no Centro Acadêmico, ocupavam então cargos de docentes na EPM, dando continuidade à sua profissão na instituição que os formara. Sáo eles também que promovem os festejos, participando das comissões, como por exemplo, Jair Xavier Guimarães e Wladimir da Prússia.

Igualmente pode-se perceber que, a partir da década de I960, a EPM demonstra maior preocupação em recolher a sua memória e de escrever a sua história. Até então, as ediçóes comemorativas eram obra do CAPB, com exceção do pequeno opúsculo de Felício Cintra do Prado editado em I95 I. Vale lembrar que o primeiro livro de fôlego, o de Paulo Mangabeira Albernaz, foi publicado no final dos anos de 1960. Em seguida, editou-se o livro sobre os quarenta anos (I 977), depois o dos sessenta anos (1993) e, finalmente, o dos setenta anos (2003). Este último, com o diferencial de ser uma obra produzida por uma empresa publicitária, sob o beneplácito de uma comissáo editorial da própria Unifesp. Nesse sentido, houve uma espécie de terceirização, em que a autoria epemista, que antes caracterizava esses livros, é substituída por redatores especializados em livros institucionais.

Vimos que, com o avançar das efemérides, certos componentes não podiam mais faltar: os atos solenes, os jantares de confraternização, os cultos religiosos, as competiçóes esportivas, os encontros científicos, as 


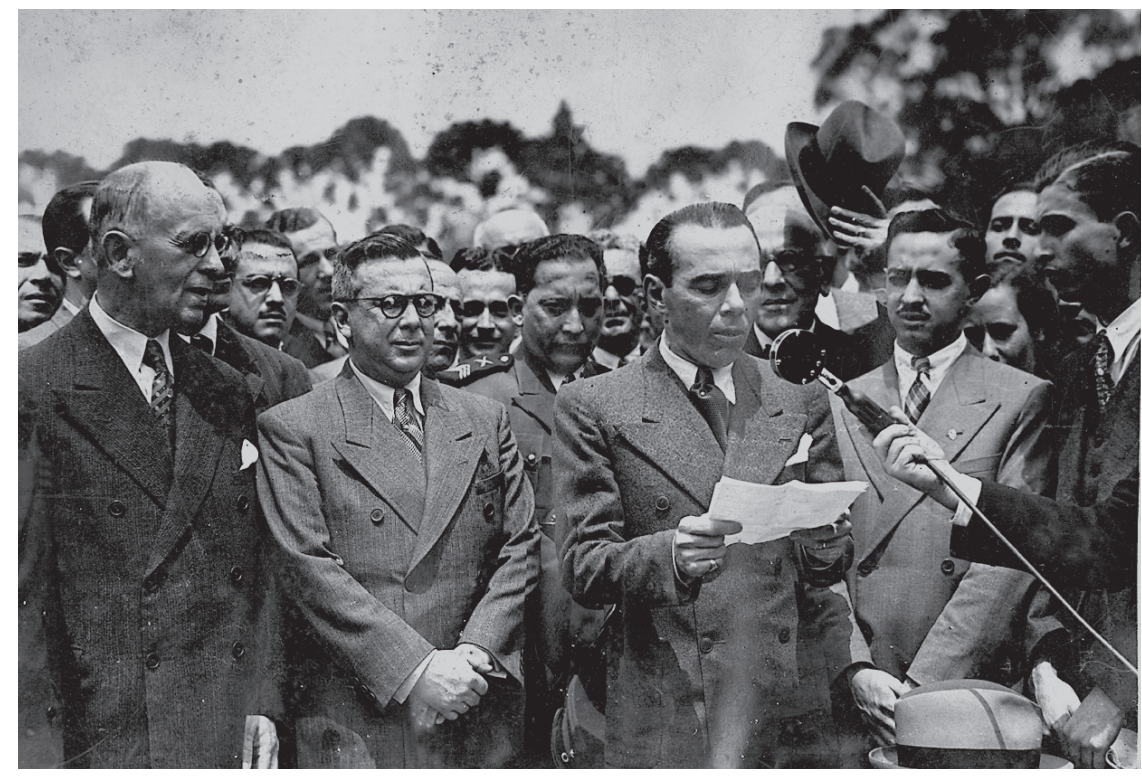

Figura i 3. Guilherme de Almeida ao microfone, discursando quando do lançamento da estaca fundamental do HSP em I936. Fonte: Acervo do сенғi, pasta $\mathrm{n}^{\mathrm{o}} 70$.

palestras, as inauguraçóes. Componentes ritualizados e ritualizantes que têm a sua materialidade, funcionalidade e significado simbólico. Dela fazem parte os discursos, as homenagens em forma de hino, poesia, minuto de silêncio, inauguraçóes de bustos e placas, livros, selos, visitas a túmulos. As vivências e as memórias narradas são depuradas em função do ato comemorativo. Não há memória total e, menos ainda, definitiva. Há, sim, uma dinâmica rememoração do passado que se inscreve no presente e da qual fazem parte o esquecimento e a omissão. Mas, como mencionado nas palavras introdutórias deste ensaio, o que prevalece é o desejo pela memória. Daí também a necessidade de produzir textos sobre a história da instituição e de transformá-la em obras comemorativas.

Nessas obras, a "história" institucional é construída como uma história que ensina, uma história que traz elementos pedagógicos, no sentido de figurar como exemplo de sucesso, de notória conquista, de capacidade em conseguir transpor as dificuldades, e por isso conter "verdades" que oferecem soluçóes para novos desafios. Nisso reside a idéia da "história magistra vitae" e uma crença na sincronicidade dos acontecimentos, ou seja, a experiência histórica de décadas passadas de alguma maneira é transposta para o momento coevo. Essa perspectiva é muito notória nos capítulos conclusivos do livro de Albernaz, nas "estaçôes" de Rosa Borges e no livro sobre os setenta anos. 
Por outro lado, as lembranças narradas pelos sujeitos participantes dessa história deixam entrever uma memória em que os mitos se repetem e engolfam a narrativa histórica. Esse movimento entre história e memória permitiu a formação de uma tradição discursiva sobre a EPM - que, desde a fundação, atravessou todos os momentos e geraçóes, por meio de retomadas e citaçóes de falas anteriores. Sinal de sua vitalidade e longevidade nos deram as palavras de Ulysses Fagundes Neto, em seu discurso quando de sua recondução ao cargo de reitor da Unifesp: "É com o espírito altamente alerta e disposto a enfrentar novos e excitantes desafios que seguiremos trabalhando pela nossa Unifesp em benefício da nossa juventude" ${ }^{172}$.

O desafio aqui se refere à nova fase da Unifesp, marcada pela expansão da universidade em novos campi e novas áreas do conhecimento, tocando na questão territorial e espacial. Diante dos "desafios", olhar para o passado propicia a certeza do sucesso vindouro. A identidade "bandeirante" e o lema da excelência são novamente evocados, bem como a bravura dos "fundadores" é lembrada:

Carregamos no nosso cerne o sentimento bandeirante do destemor ao desconhecido, do desbravador de novos caminhos, além do desejo constante de expandir nossas fronteiras. Crescer com excelência de qualidade é nosso lema maior, a universidade do futuro continua sendo construída, estamos honrando nossos fundadores que tão galhardamente enfrentaram e superaram as imensas barreiras que se lhes antepuseram, mas acreditaram que a luta valia a pena e que a bandeira por eles empunhada continuaria eternamente tremulando imaculada e gloriosa ${ }^{173}$ [Figura I3] .

A reiteração das imagens da fundação nos sucessivos "tempos presentes" procura dar ares de profecia às idéias de Guilherme de Almeida, em I936, na época da fundação da EPM:

[...] aí está germinada a semente, aí está florescido o ideal, aí está frutificado o empreendimento. Estamos fazendo a nossa parte em manter viva a tradição e o legado que nos foi confiado. Frutificamos e nos multiplicamos. Estamos edificando com amor em uma ação conjunta e solidária uma Unifesp para todos cada vez maior e ainda melhor, a serviço de São Paulo e para a soberania do Brasil ${ }^{174}$.

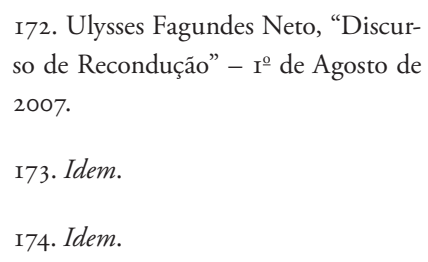

